\section{Pacific Northwest}

National Laboratory

Operated by Battelle for the

U.S. Department of Energy

\title{
Facility Effluent Monitoring Plan for the 331 Complex
}

MY Ballinger

October 2002

Prepared for the U.S. Department of Energy

under Contract DE-AC05-76RL01830

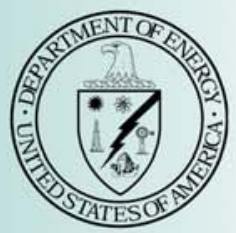




\title{
DISCLAIMER
}

This report was prepared as an account of work sponsored by an agency of the United States Government. Neither the United States Government nor any agency thereof, nor Battelle Memorial Institute, nor any of their employees, makes any warranty, express or implied, or assumes any legal liability or responsibility for the accuracy, completeness, or usefulness of any information, apparatus, product, or process disclosed, or represents that its use would not infringe privately owned rights. Reference herein to any specific commercial product, process, or service by trade name, trademark, manufacturer, or otherwise does not necessarily constitute or imply its endorsement, recommendation, or favoring by the United States Government or any agency thereof, or Battelle Memorial Institute. The views and opinions of authors expressed herein do not necessarily state or reflect those of the United States Government or any agency thereof.

\author{
PACIFIC NORTHWEST NATIONAL LABORATORY \\ operated by \\ BATTELLE \\ for the \\ UNITED STATES DEPARTMENT OF ENERGY \\ under Contract DE-AC05-76RL01830
}

Printed in the United States of America
Available to DOE and DOE contractors from the Office of Scientific and Technical Information,
P.O. Box 62, Oak Ridge, TN 37831-0062;
ph: (865) 576-8401
fax: $(865)$ 576-5728
email: reports@adonis.osti.gov

\begin{abstract}
Available to the public from the National Technical Information Service, U.S. Department of Commerce, 5285 Port Royal Rd., Springfield, VA 22161 ph: (800) 553-6847 fax: $(703) 605-6900$ email: orders@ntis.fedworld.gov online ordering: http://www.ntis.gov/ordering.htm
\end{abstract}

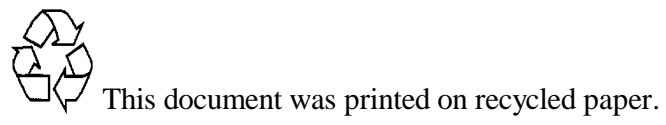


PNNL-12158, Rev. 1

\section{Facility Effluent Monitoring Plan for the 331 Complex}

Oclober 2002

Prepared for the U.S. Department of Energy under Contract DE-AC06-76RL01830 


\section{FACILITY EFFLUENT MONITORING PLAN FOR THE 331 COMPLEX}

Prepared by:

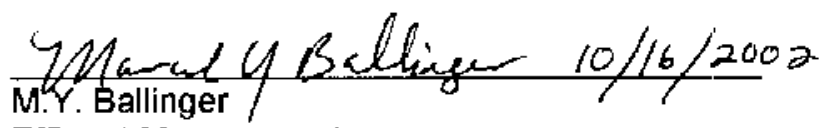

Effluent Management

Approved for Use and Application by:

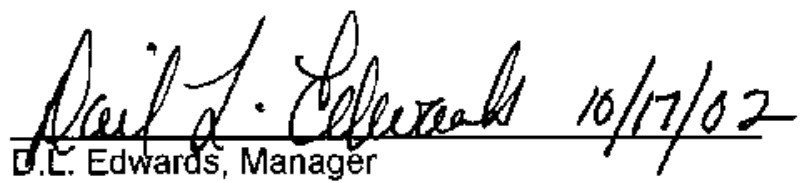

Effluent Management
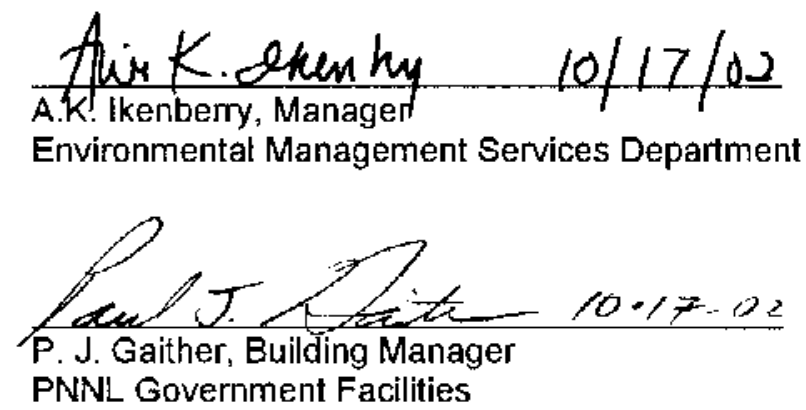

Pacific Northwest National Laboratory Operated by Battelle for the U. S. Department of Energy 


\section{Summary}

This Facility Effluent Monitoring Plan (FEMP) has been prepared for the 331 Building Life Sciences Laboratory and associated support facilities at the Pacific Northwest National Laboratory (PNNL) to meet the requirements in DOE Order 5400.1, "General Environmental Protection Programs." This FEMP has been prepared for the 331 Complex primarily because it has a "major" (potential to emit $>0.1 \mathrm{mrem} / \mathrm{yr}$ ) emission point for radionuctide air emissions according to the annual National Emission Standards for Hazardous Air Pollutants (NESHAP) assessment performed. This section summarizes the airborne and liquid effluents and the inventory based NESHAP assessment for the facility. The complete monitoring plan includes characterization of effluent streams, monitoring/sampling design criteria, a description of the monitoring systems and sample analysis, and quality assurance requirements.

The 331 Complex, at PNNL, houses research in lite sciences, materials characterization and testing, and waste management activities. The facility is designed to accommodate the use of radioactive and hazardous materials to conduct these activities. Radioactive material storage and usage occur primarily in the 331 Building with sealed sources in $331 \mathrm{G}$ and $331 \mathrm{H}$.

\section{Airborne Effluents}

Potential radioactive airborne emissions in the 331 Complex have been assessed and all potential airborne release pathways identified. The primary stack at the 331 Building (EP-331-01-V) is currently registered with the Washington State Department of Health, as required by WAC 246-247 Radiation Protection - Air Emissions, and is continuously sampled for alpha and beta emitting radioisotopes associated with particulate matter. The stack sampler was designed in accordance with 40 CFR 61 . Emissions of volatile organic compounds and toxic air pollutants have been characterized and determined to be within applicable permits and regulatory limits.

\section{Liquid Effluents}

Liquid effluent release pathways in the 331 Facility are either administratively or physically controlled. Connections in the laboratory spaces that have the potential for inadvertent release of chemicals or radioactive material to process sewers (e.g., floor drains) have been plugged. The remaining drains have been posted with labels stating the type of drain and liquid effluent disposal controls. These primarily include laboratory sink and hood drains and also some equipment room floor.

The 331 Complex has three sewer systems: the process sewer (PS), the sanitary sewer (SNS), and the Aquaculture system. PS effluent lines from the facility enter into the 300 Area liquid effluent system operated by Fluor Hanford. The PS is monitored by Fluor Hanford prior to discharge to the Columbia River via the 300-Area Treated Effluent Disposal Facility (TEDF). The 300 Area SNS discharges to the City of Richland, Publicly-Owned Treatment Works (POTW) under a contract agreement between DOE and the City. The Aquaculture System has been exempted from National Pollutant Discharge Elimination System permitting requirements but is monitored as a best management practice by PNNL, prior to discharge to the Columbia River.

\section{NESHAP Determination}

An inventory-based method was used to estimate the maximum offsite dose from potential airborne releases in accordance with 40 CFR 61 , Subpart $H$. The potential unmitigated dose has exceeded or closely approached $0.1 \mathrm{mrem} / \mathrm{yr}$ since 1998. A number of chemicals in the building were identified in greater than Reportable Quantity, as defined in 40 CFR 302. This meets both of the DOE/RL criteria for preparing a FEMP. 
This page intentionally left blank. 


\section{Contents}

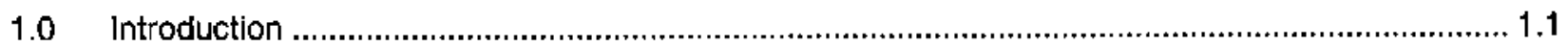

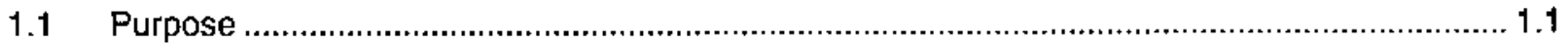

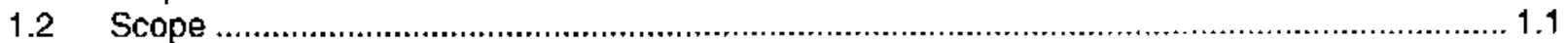

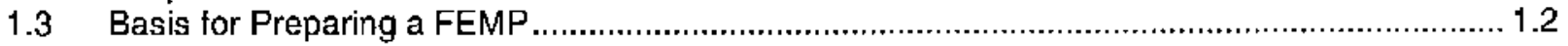

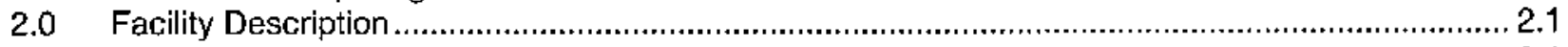

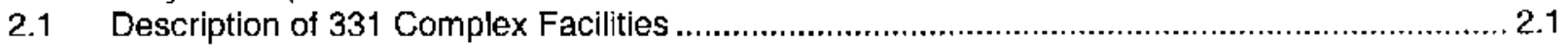

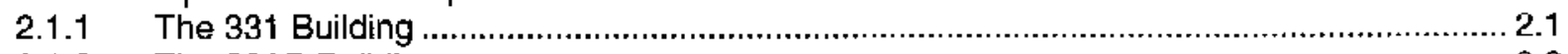

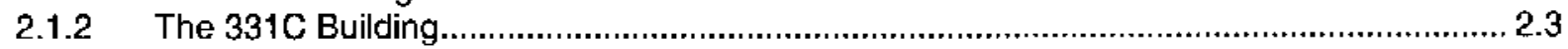

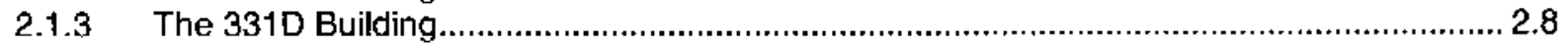

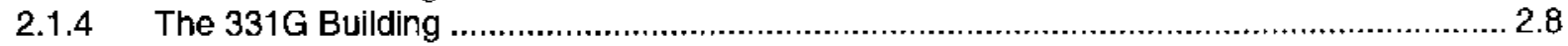

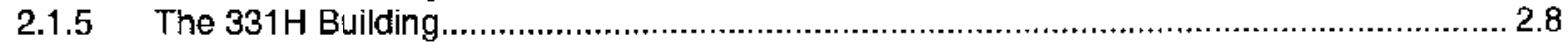

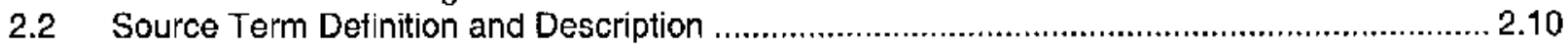

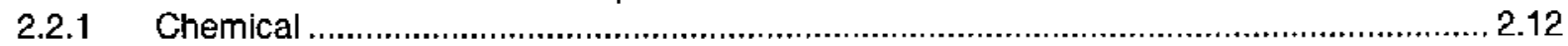

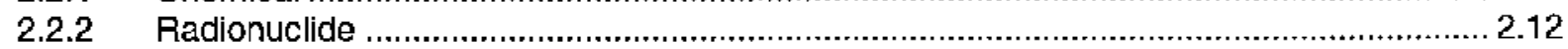

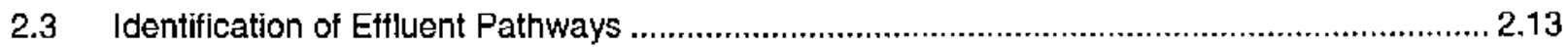

2.3.1 Gaseous and Aerosol Emission Pathways ............................................................... 2.13

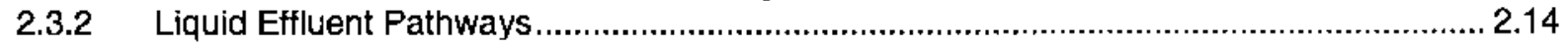

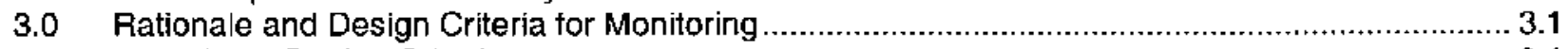

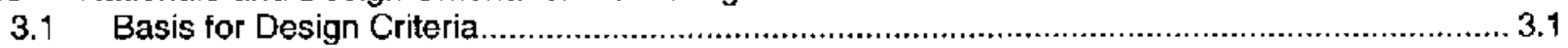

3.2 Criteria for Radiological Air Emission Sampling and Monitoring ............................................ 3.2

3.2.1 Sampling System Performance Criteria................................................................... 3.2

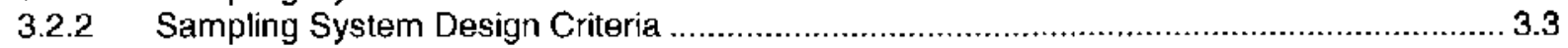

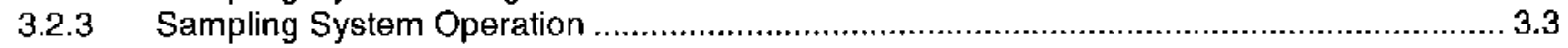

3.3 Historical Monitoring/Sampling Data for Effluent Streams ...................................................... 3.4

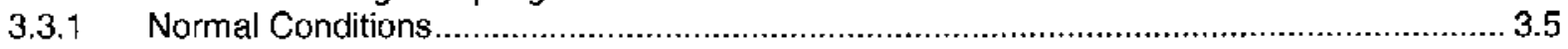

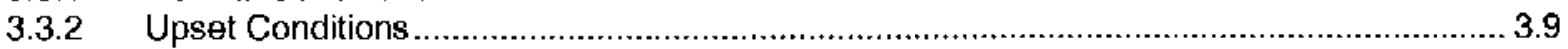

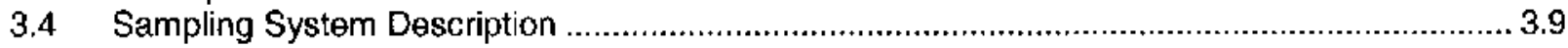

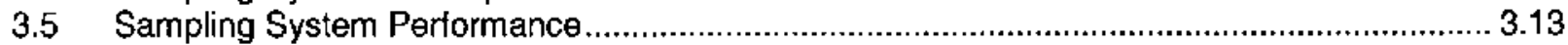

3.5.1 Stack Radionuclide Sampling System Performance ................................................... 3.14

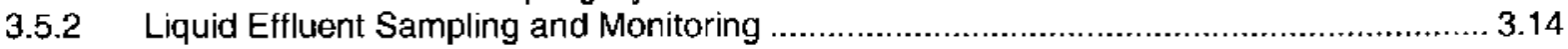

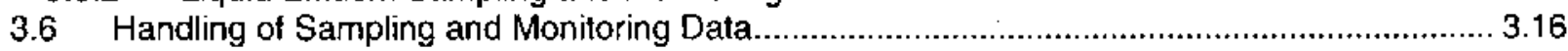

3.6.1 Radiological Air-Emission Data................................................................................. 3.16

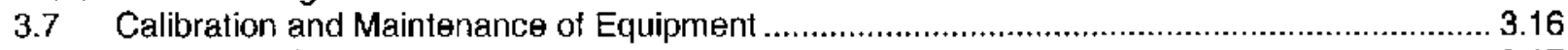

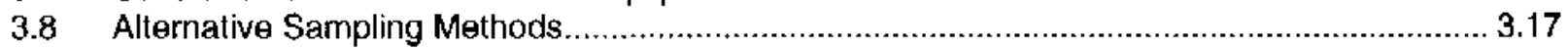

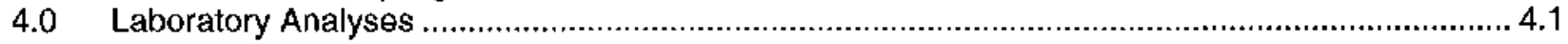

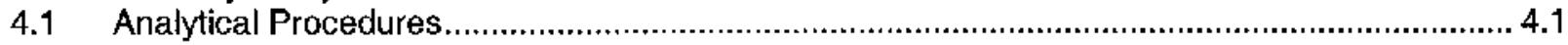

4.1.1 Determination of Alpha and Beta Activity on Particulate Air Filters ................................. 4.1

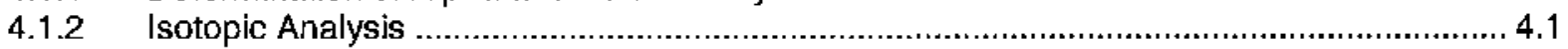

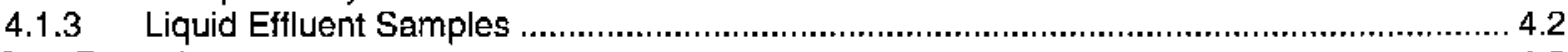

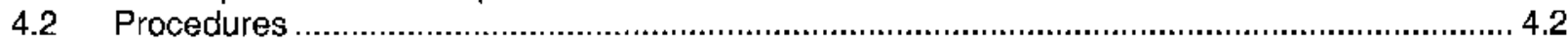

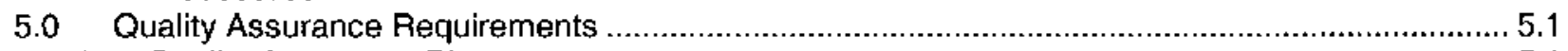

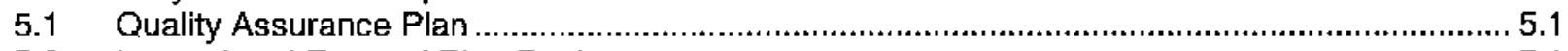

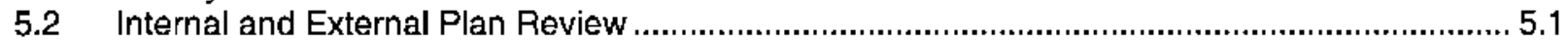

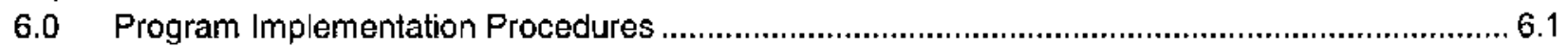

6.1 interface with the Near-Facility Environmental Monitoring Program .........................................6.1

6.2 Interface with the Operational Environmental Surveillance Program....................................... 6.1

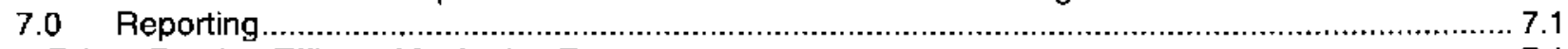

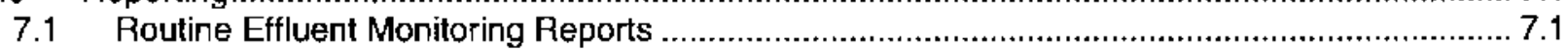

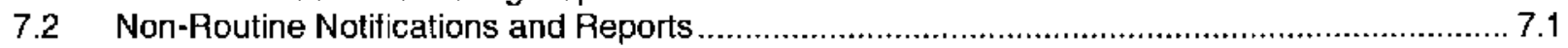

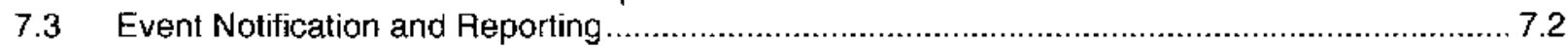

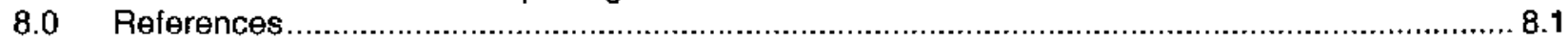


Appendix A - Projection of Offsite Emission Dose.

Appendix B - Non-radioactive Hazardous Materials Characterization.................................................8.1

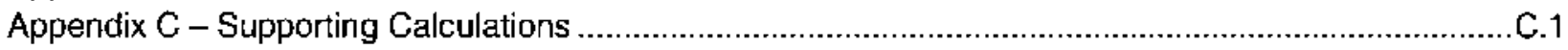

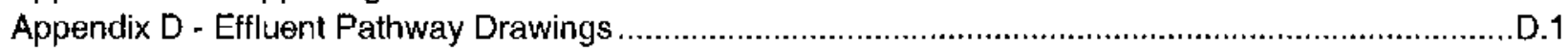

\section{Figures}

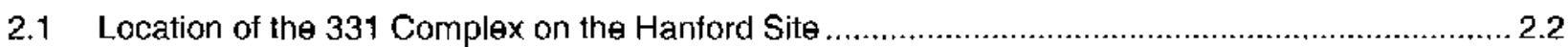

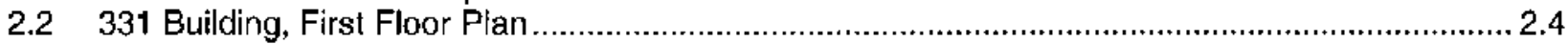

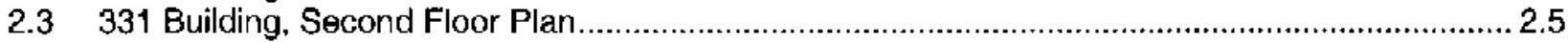

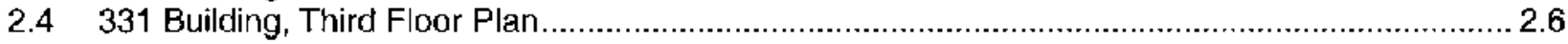

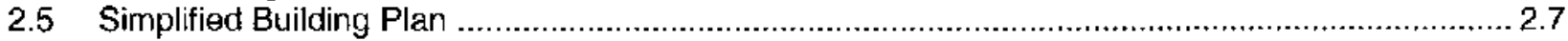

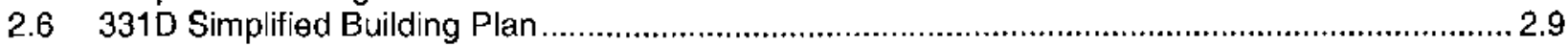

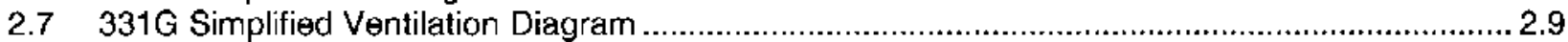

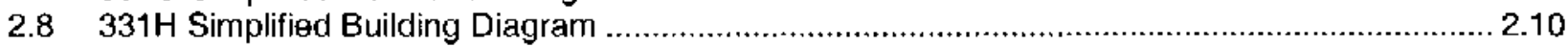

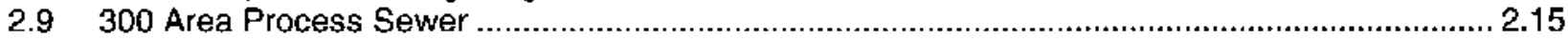

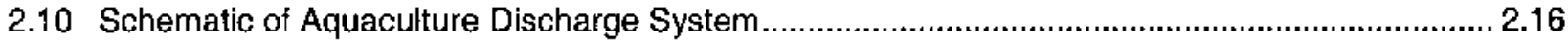

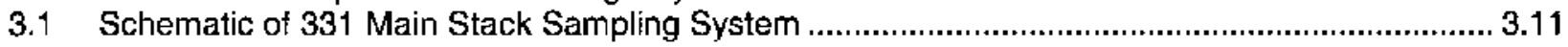

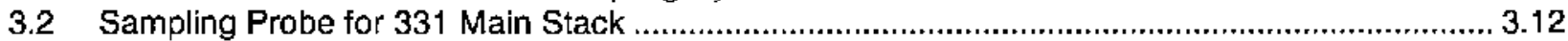

3.3 331 Main Stack Sampling System Configuration................................................................... 3.13

3.4 Schematic of 331 Complex PS Sampling and Monitoring System .......................................... 3.15

\section{Tables}

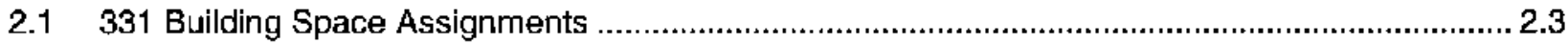

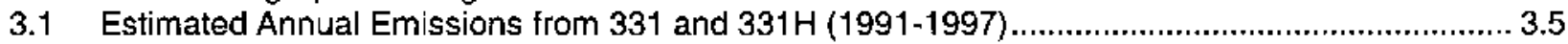

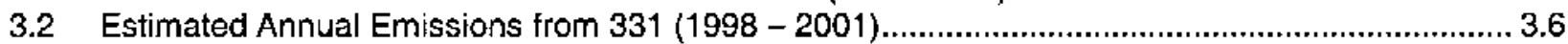

3.3 Summary of Historical Liquid Monitoring/Sampling .................................................................. 3.6

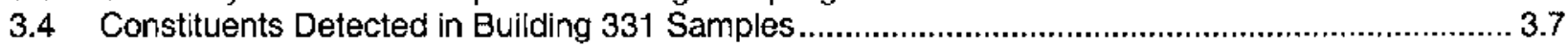

3.5 Off-Normal and Unusual Occurrences in the 331 Complex ...................................................... 3.9

3.6 Detection of Significant Radionuclides in 331 Stack Emissions .............................................. 3.14

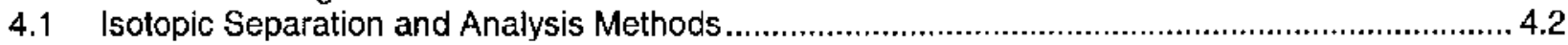




\section{Acronyms List}

\begin{tabular}{|c|c|}
\hline $\begin{array}{l}\text { AMAD } \\
\text { ANSI } \\
\text { AOP } \\
\text { ASQC }\end{array}$ & $\begin{array}{l}\text { activity median aerodynamic diameters } \\
\text { American National Standards Institute } \\
\text { air operating permit } \\
\text { American Society for Quality Control }\end{array}$ \\
\hline $\mathrm{BCAA}$ & Benton Clean Air Authority \\
\hline $\begin{array}{l}\text { CFR } \\
\text { CMC } \\
\text { COC }\end{array}$ & $\begin{array}{l}\text { Code of Federal Regulations } \\
\text { Chemical Measurement Center } \\
\text { chain of custody }\end{array}$ \\
\hline $\begin{array}{l}\text { DOE } \\
\text { DOE/RL }\end{array}$ & $\begin{array}{l}\text { U.S. Department of Energy } \\
\text { U.S. Department of Energy/Richland Operations Office }\end{array}$ \\
\hline $\begin{array}{l}\text { EMP } \\
\text { EPA }\end{array}$ & $\begin{array}{l}\text { environmental monitoring plan } \\
\text { U.S. Environmental Protection Agency }\end{array}$ \\
\hline FEMP & Facility Effluent Monitoring Plan \\
\hline HEPA & high-efficiency particulate air \\
\hline $\begin{array}{l}\text { MBA } \\
\text { MDA }\end{array}$ & $\begin{array}{l}\text { material balance area } \\
\text { minimum detectable activity }\end{array}$ \\
\hline $\begin{array}{l}\text { NESHAPS } \\
\text { NPDES } \\
\text { NOC }\end{array}$ & $\begin{array}{l}\text { National Emission Standards for Hazardous Air Pollutants } \\
\text { National Pollutant Discharge Elimination System } \\
\text { notice of construction }\end{array}$ \\
\hline OED & offsite emission dose \\
\hline $\begin{array}{l}\text { PNNL } \\
\text { PS } \\
\text { POTW } \\
\text { PTE }\end{array}$ & $\begin{array}{l}\text { Pacific Northwest National Laboratory } \\
\text { process sewer } \\
\text { publicly owned treatment works } \\
\text { potential to emit }\end{array}$ \\
\hline QA & quality assurance \\
\hline $\mathrm{RQ}$ & reportable quantity \\
\hline $\begin{array}{l}\text { SBMS } \\
\text { SNS } \\
\text { SOP } \\
\text { SOW }\end{array}$ & $\begin{array}{l}\text { Standards Based Management System } \\
\text { sanitary sewer } \\
\text { safe (or standard) operating procedure } \\
\text { statement of work }\end{array}$ \\
\hline TEDF & Treated Effluent Disposal Facility \\
\hline $\begin{array}{l}\text { WAC } \\
\text { WDOE } \\
\text { WDOH }\end{array}$ & $\begin{array}{l}\text { Washington Administrative Code } \\
\text { Washington Department of Ecology } \\
\text { Washington Department of Health }\end{array}$ \\
\hline
\end{tabular}


This page intentionally left blank. 


\subsection{Introduction}

It is the policy of the U.S. Department of Energy (DOE) to conduct its operations in an environmentally safe and sound manner and to conduct programs to protect the environment and the public. The Pacific Northwest National Laboratory (PNNL) is committed to providing a safe and healthy working environment for all staff; protecting the general public and the environment from unacceptable environmental, safety, and health risks; and operating in a manner that protects and restores the environment. To implement these policies, effluent-monitoring programs at PNNL must meet high standards of quality and credibility.

\subsection{Purpose}

DOE Order 5400.1 (DOE 1988), "General Environmental Protection Programs," states the following objective for environmental monitoring programs:

demonstrate compliance with legal and regulatory requirements imposed by applicable Federal, State, and local agencies; confirm adherence to DOE environmental protection policies; and support environmental management decisions (Section IV-1).

Plans must be prepared for each site, facility, or process that uses "significant pollutants or hazardous materials" (DOE 1988, Section, IV-2). These requirements are being met through the environmental monitoring program conducted for the Hanford Site and described by the DOE Richland Operations Office (DOE/RL) in the Hanford Site Environmental Monitoring Plan (EMP)(DOE 2000).

The EMP identifies and discusses two major activities as specified by DOE 5400.1: 1) effluent monitoring, and 2) environmental surveillance. Because the Hanford Site contains a number of facilities with effluent monitoring needs, individual facility effluent monitoring plans (Facility Effluent Monitoring Plans [FEMPs]) are prepared for those facilities to implement effluent monitoring requirements. This report primarily supplies information on effluent monitoring for the 331 Building. Other facilities in the 331 Complex are included in this FEMP because of their close integration with the 331 Building activities and systems. The information provided in this FEMP is current as of the time of FEMP issuance. DOE Order 5400.1 requires the EMP to be reviewed annually and updated every 3 years. Update of this FEMP will also occur on a 3-year schedule.

\subsection{Scope}

Characterizing the radioactive and nonradioactive constituents in inventory and in waste streams provides the underlying rationale for sampling and monitoring programs. Currently, continuous sampling for radionuclide air emissions is required for the 331 Building main stack because of the radionuclide inventory. Sampling for air chemical emissions is not required for any of the 331 Complex facilities.

For liquid waste streams, routine compliance sampling of the 331 Building aquaculture system is no longer required under the Hanford Site National Pollutant Discharge Elimination System (NPDES) Permit for the aquaculture outfall discharge to the Columbia River. This system was exempted during permit revision in 1999. PNNL continues to sample and monitor the discharge as a best management practice under an agreement with DOE/RL. Compliance sampling for the other liquid streams from the 331 Complex (process sewer [PS] and sanltary sewer [SNS]) are incorporated into 300 Area compliance sampling activities conducted by Fluor Hanford for process waste streams and for sanitary discharges to the City of Richland from the 300 Area, as required. PNNL is responsible for ensuring that liquid wastes cischarged to these systems meet sewer system waste-acceptance criteria program requirements.

A major activity of the FEMP effort is to identify the liquid and air release pathways (e.g., identify all access points to the various sewers and all radioactive emission release pathways) under normal operations and during process upset conditions. These are verified on as-built drawings that are maintained as Key Drawings in PNNL's Drawings System. This verification has been performed for the $331,331 \mathrm{G}$, and $331 \mathrm{H}$ Buildings for both ventilation ducting and liquid effluent piping and for 331 $\mathrm{D}$ for liquid effluent piping only. The $331 \mathrm{C}$ and $331 \mathrm{D}$ Buildings have no forced air ventilation systems, and, $331 \mathrm{C}$ has no liquid effluent drains. 
The method of characterization discussed in this plan identifies potential pollutants at the point of generation and potential upset conditions that are likely to occur and evaluates the potential for those materials to enter an effluent stream.

\subsection{Basis for Preparing a FEMP}

A FEMP was determined to be needed for the 331 Building because of the quantity of radionuclides and chemicals in the building. The 331 Building has a potential to emit (PTE) close to or just over $0.1 \mathrm{mrem} / \mathrm{yr}$ for radionuclides and has numerous chemicals in excess of their Reportable Quantity (RQ) value. This meets both $D O E / R L$ criteria for the preparation of a FEMP. A list of radioactive material in the facility can be found in Appendix A. A list of chemicals in greater than the RQ is provided in Appendix $B$. 


\subsection{Facility Description}

The 331 Complex is located in the 300 Area of Hanford (see Figure 2.1) and currently consists of the following buildings: $331,331 \mathrm{C}, 331 \mathrm{D}, 331 \mathrm{G}$, and $331 \mathrm{H}$. The 331 Building was constructed in 1970 for biological and botanical research. Associated buildings (331A to $331 \mathrm{~J}$ ) were constructed during the 1970 s for specialized support functions. Many of the support buildings have assumed new functions over the years, as research needs changed. Several buildings have been vacated and torn down. However, work in the main research facility (331) continues; and, the radiological inventory has increased with the closure of other PNNL-operated 300 Area facilities so that continuous monitoring for radiological airborne emissions is now required.

\subsection{Description of $\mathbf{3 3 1}$ Complex Facilities}

Descriptions are provided for the main 331 Building and active remaining support buildings, including physical and process descriptions. Information on activities and physical descriptions was obtained from Facility Use Agreements which are written agreements between PNNL Facility Operations and the immediate manager for each organization occupying the building. Significant changes in activities are reflected in updated Facility Use Agreements. Changes that could affect facility effluent monitoring are captured through PNNL procedures as described in Section 2.2.

\subsubsection{The 331 Building}

\section{Activities}

One of the primary functions of the Life Sciences Laboratory (331 Building) is to provide research capabilities to study the health effects of chemicals and radiation and the uptake and transformation effects in soils, plants, animals, microorganisms, and solutions when they are exposed to radiation. Current projects are being conducted to examine these effects in animals (rodents) and in cells grown in culture. Much of this work focuses on molecular level changes and uses very small amounts of radioactive materials for tracing biological molecules. Studies are conducted to:

- Understand molecular and cellular processes resulting from insult by physical and chemical agents. This work is to provide data that serves as a basis for precise cross-species and lowdose extrapolation of health risks and to supply information to understand disease mechanisms, levels, and effect.

- Determine dose-response relationships for various health endpoints and the mechanisms of effects from electromagnetic frequency exposure and lightweight magnetic shielding materials.

- Study microorganisms and/or their processes in various environments. Research emphasis is currently in subsurface microbiology, including the physiology and ecology of subsurface microorganisms, degradation of organic contaminants and bioremediation, enzymatic reduction of metals, and biogeochemical cycling of nutrients.

- Investigate macromolecular structure and dynamics and probe the consequences of observables on molecular function. The structures under study include:

nucleic acid sequences chosen to model radiation- (or chemically-) damaged DNA

- RNAs and their various complexes

- epidermal cells and mammary cells to study the effects of turnor formation

- transient species generated via oxidative processes in biological systems

- metalloproteins that can concentrate or detoxify pollutants from the environment clays, oxides, and metals supported on oxide surfaces with or without adsorbates.

An outcome of this research program activity is the development of instrumentation and analytical methods that are applied in an innovative manner to facilitate a new level of understanding of structure and function that can be applied to other important research initiatives.

Another function of the 331 Building is to provide aquaculture research capabilities. Aquaculture research conducted in the 331 Building provides an integrated approach to characterizing and monitoring aquatic ecosystems by developing and deploying new technologies and methods. Research focuses on the 
impacts of water-use practices to fisheries and wildlife and the response of the aquatic ecosystems to engineered structures and to natural and man-induced stresses. Hydrology research on groundwater and surface water flow and transport is also conducted.

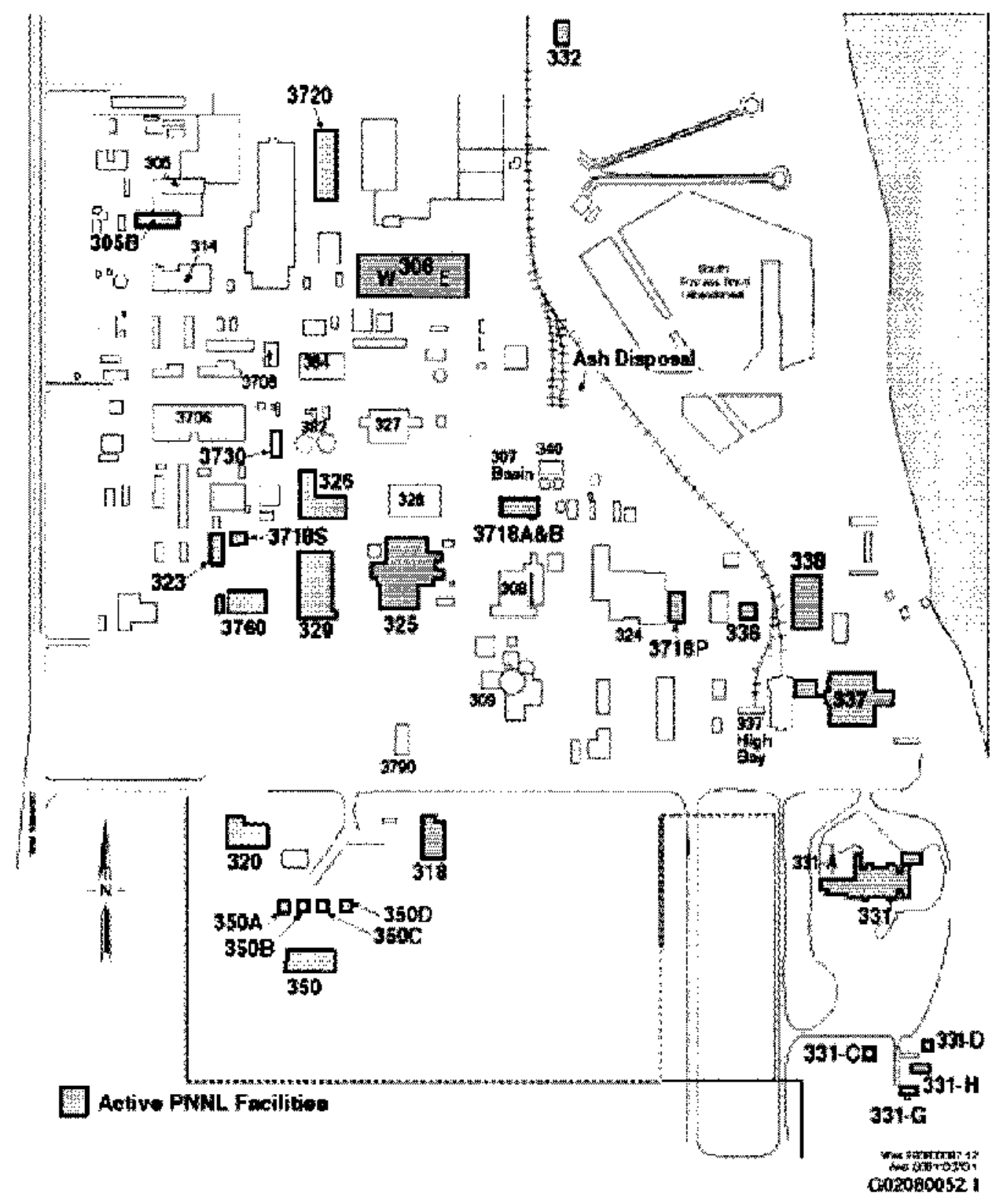

Figure 2.1. Location of the 331 Complex on the Hanford Site 
In addition, research work in the 331 Building is conducted to promote an understanding of the chemical and biological processes that govern the mobility and degradation of a range of inorganic, organic, and radioactive contaminants in soils, sediments, and groundwater systems. This work may use radioactive materials in more significant quantities.

Finally, research in the 331 Building is conducted to obtain measurements of exposures to physical and chemical agents. This includes associated research to interpret and validate measurements for providing customers with more accurate and relevant information on worker and public exposures. It also involves providing assistance in radioisotope technology to the medical community for diagnosing and treating diseases, including research in the separation, purification, production, and delivery of medically useful isotopes.

\section{Physical Description}

The 331 Building physical structure consists primarily of two laboratory floors with a mechanical-electrical service floor sandwiched in between. Blending into the building to the west and north is additional singlestory laboratory space. Extending from the west end of the building are two wings protruding south that were animal kennels that are currently being removed. The administrative office area is a three-story building with a two-story addition on the northeast side. Figures 2.2 through 2.4 provide floor plans of the 331 Building. Table 2.1 lists the building-space assignments.

Table 2.1. 331 Building Space Assignments

\begin{tabular}{|l|l|}
\hline Description & \multicolumn{1}{|c|}{ Dimensions } \\
\hline Office Space & $14,000 \mathrm{ft}^{2}$ \\
\hline Laboratories & $39,300 \mathrm{ft}^{2}$ \\
\hline Common & $61,100 \mathrm{ft}^{2}$ \\
\hline Storage & $700 \mathrm{ft}^{2}$ \\
\hline Total Area & $115,100 \mathrm{ft}^{2}$ \\
\hline
\end{tabular}

The 331 Building has a 600-ton chiller on the northwest side of the building and a 200-ton chiller for zone cooling in the equipment room on the first floor. The ventilation system is able to maintain 15 to 20 air changes per hour in the animal quarters and 4 changes per hour in the office spaces. High-efficiency particulate air (HEPA) filtration is provided in areas where work with radioactive materials is performed. Some areas have two stages of HEPA filtration. Detailed ventilation system drawings are provided in Appendix D.

Utility services for the 331 Building include hot, cold, process, sanitary, raw river, raw well, and deionized water; sanitary sewer, PS, and aquaculture system; cage washers; compressed air; laboratory vacuum; stearn; and electrical (two 1000 kVA transformers provide normal power). Safety/emergency equipment installed in the building includes safety showers, eyewash stations, fire extinguishers, fire alarms and suppression, and storage cabinets for flammables.

\subsubsection{The 331C Building}

The $331 \mathrm{C}$ Building, previously known as an Animal Care Facility Storage, is used as general warehouse space to store government standard furniture and research equipment for future use. This facility also has a satellite accumulation area for hazardous waste and a storage area outside for low-level waste. Some maintenance staft have office space in the building.

The 331C Building is a Butler-type building, $100 \mathrm{ft}$ by $50 \mathrm{ft}$, erected on a concrete slab south of the 331 Building (see Figure 2.5). All 5,000 $\mathrm{ft}^{2}$ is considered storage or common space. The building is heated with electric space heaters, but has no forced air ventilation. No process water supply or liquid effluent piping or drains are provided. Electrical service is provided with a 125-amp main power supply. Safety/emergency equipment installed in the building includes fire extinguishers, fire alarm, and suppression systems. 


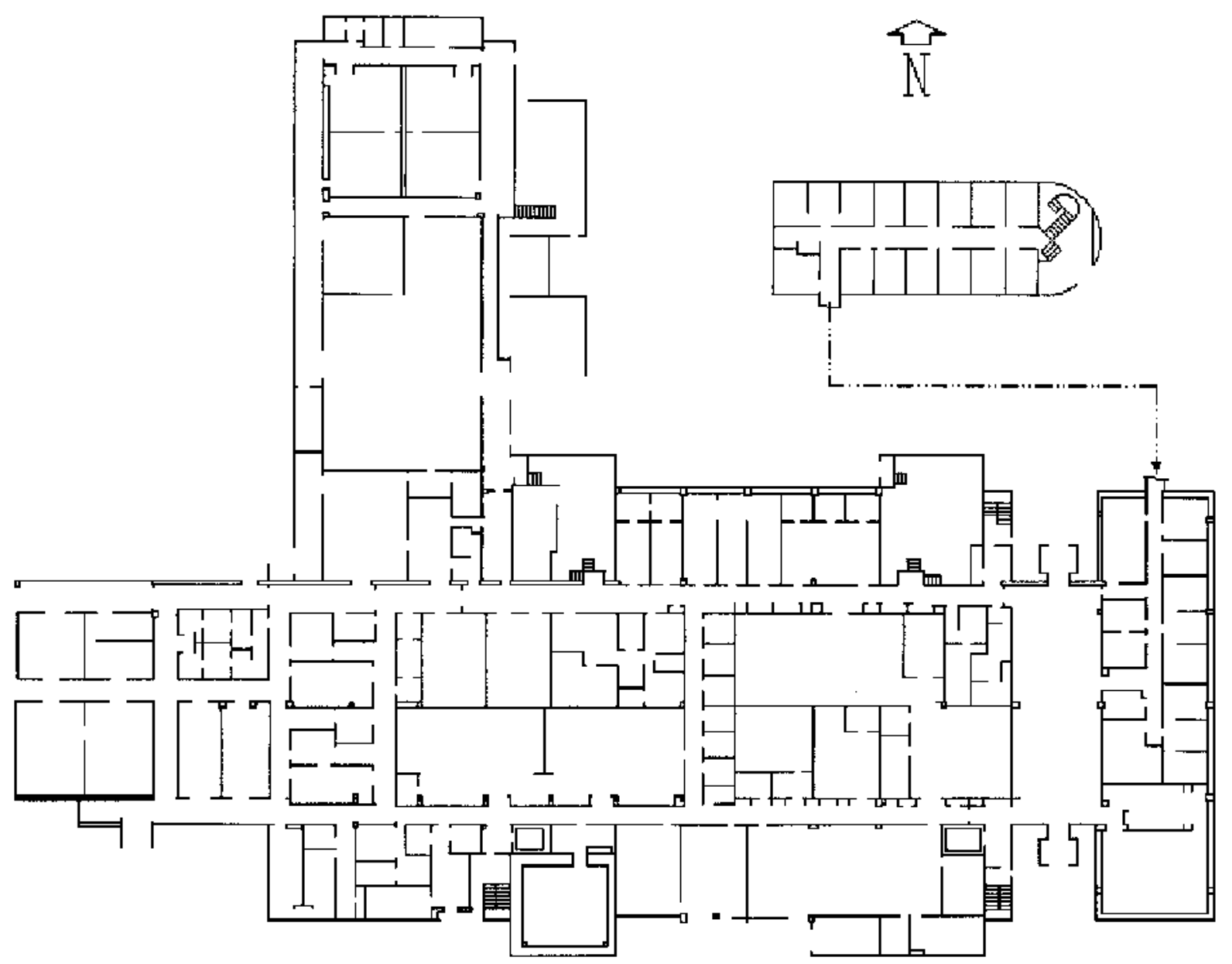

Figure 2.2. 331 Building, First Floor Plan 


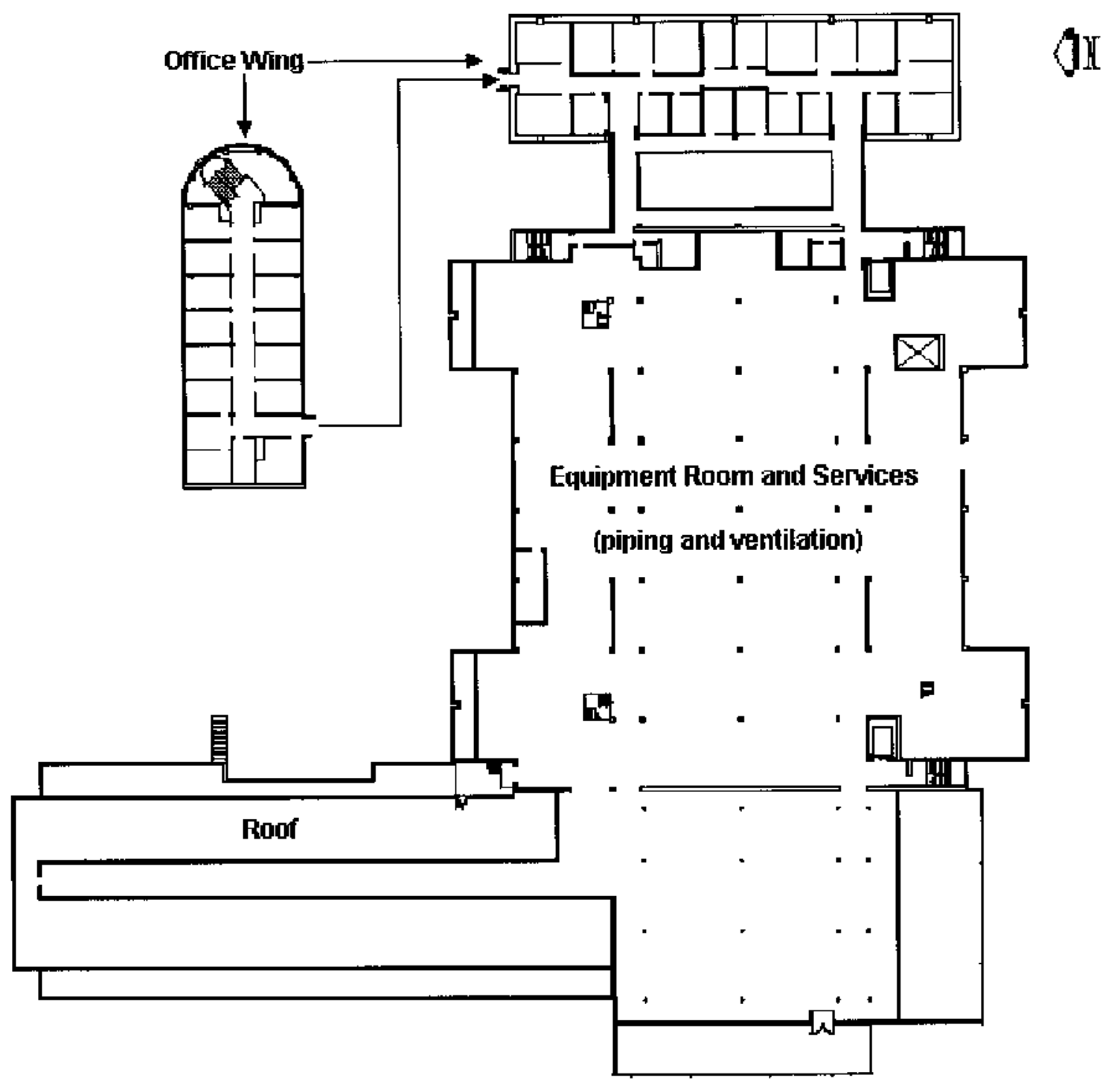

Figure 2.3. 331 Building, Second Floor Plan 


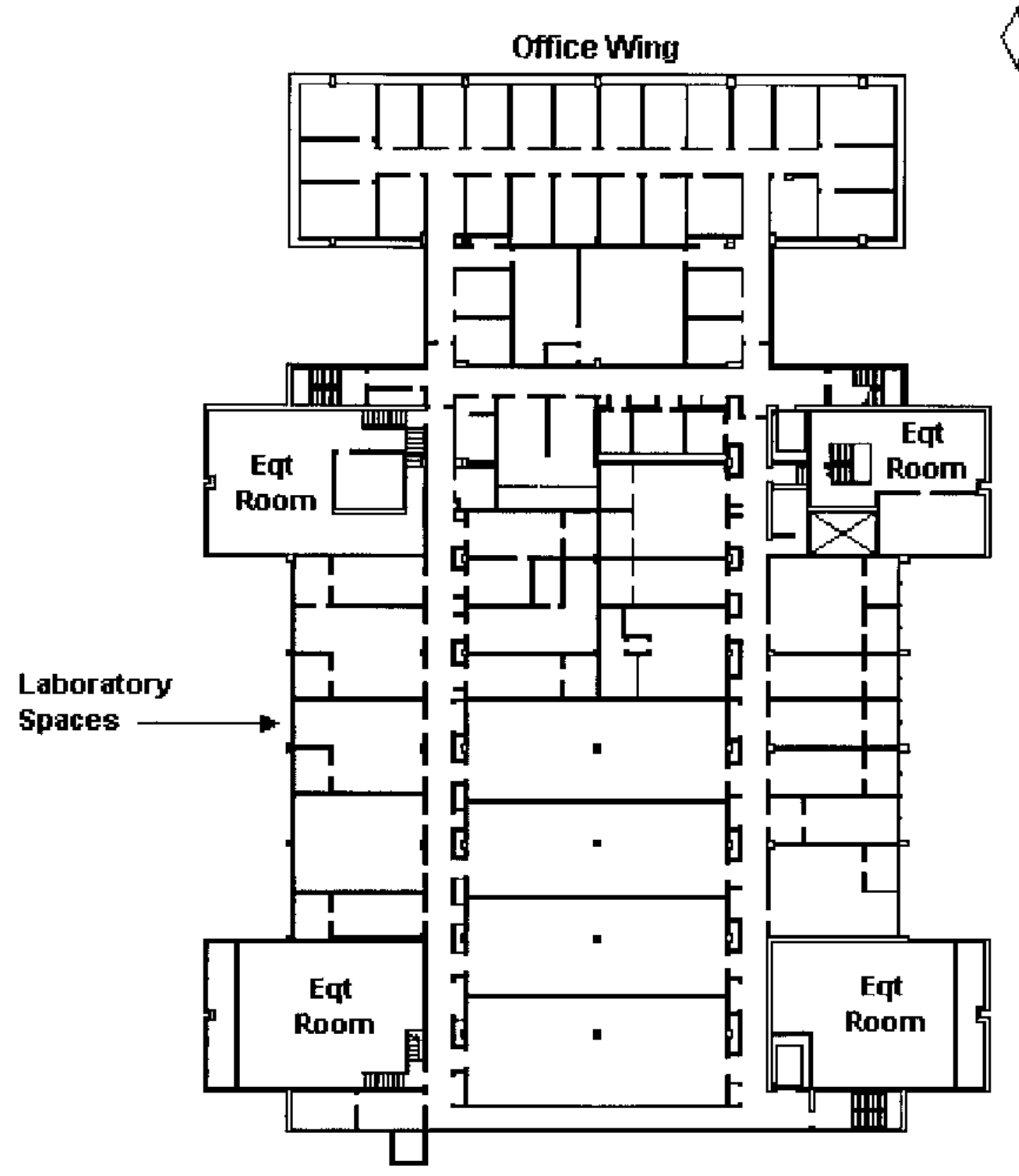

Figure 2.4. 331 Building, Third Floor Plan 

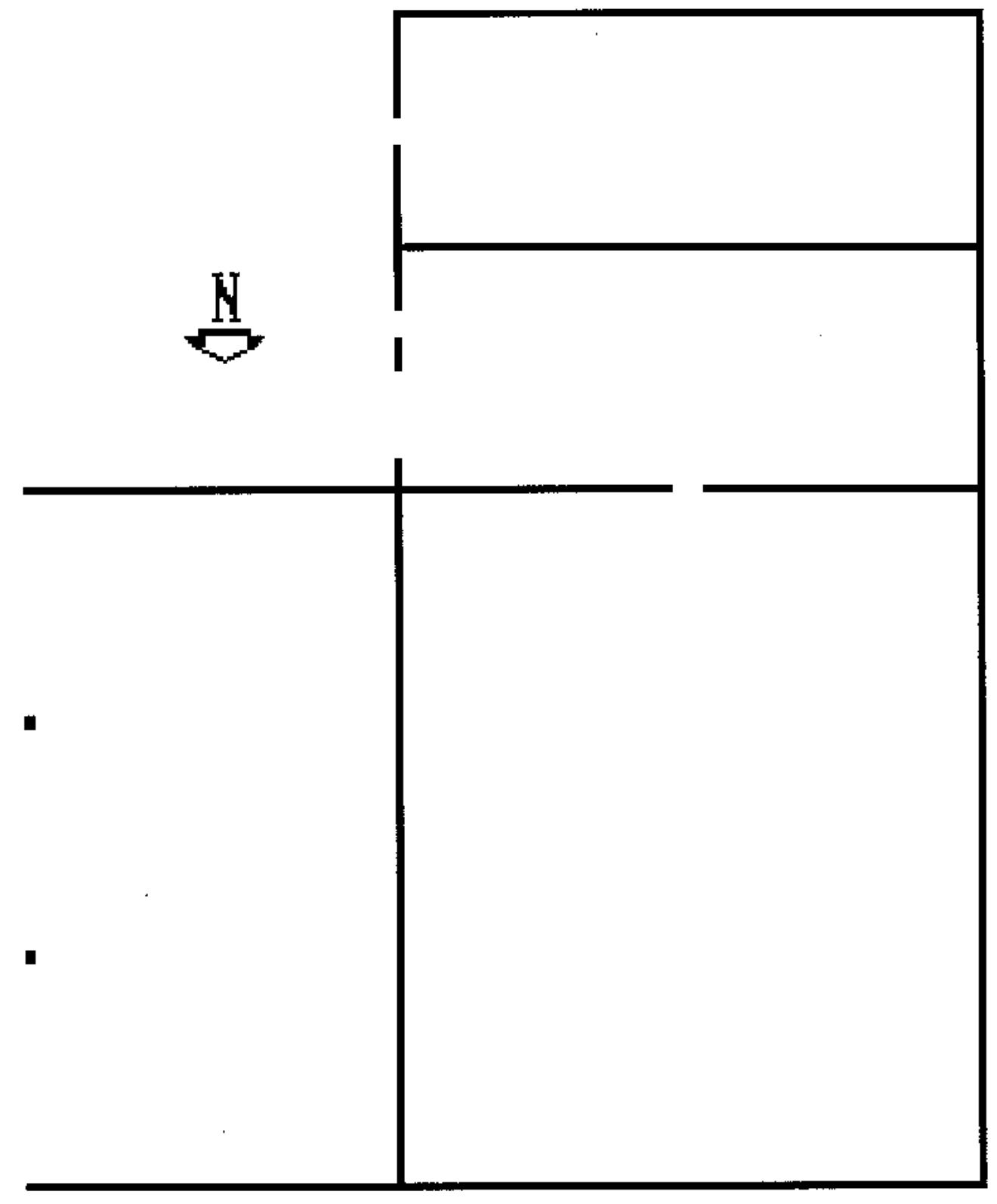

Figure 2.5. 331C Simplified Building Plan 


\subsubsection{The 331D Building}

The 331D Building, which was used in the past as a biomagnetic effects laboratory, is used to store equipment and supplies, including portable samplers, $\mathrm{pH}$ meters, bottles, buffer solutions, and concentrated dyes in support of PNNL- and Battelle-compliance monitoring activities. Non-radioactive wastewater samples are temporarily stored before shipment to various analytical laboratories.

Additionally, chemicals used in facility and 300-Area mechanical systems are stored in a back room. One room is used as an office/shop space in support of some maintenance activities.

The $331 \mathrm{D}$ Building is a semi-high bay, prefabricated, metal Butler-type building erected on a concrete slab to the southeast of the 331 Building. The structure is approximately $42 \mathrm{ft}$ by $32 \mathrm{ft}$ and was originaliy built as an animal-waste treatment facility. It was converted in 1977 to a biomagnetic effects laboratory where electromagnetic field studies were conducted on rats (Gerber 1992). It currently is being used primarily by PNNL's Effluent Management Group to store effluent sampling and monitoring equipment, by 300-Area Maintenance Services to store bulk chemicals used in various mechanical systems throughout the $\mathbf{3 0 0}$ Area, and as a shop/office space supporting machinists in the $\mathbf{3 3 1}$ Complex. It has three large rooms, one of which is equipped with a sink, cabinets, and a counter top. This room, with about one-third of the floor space, is considered a wet and dry lab. The other two rooms, which constitute the remaining two-thirds of the $1,200-\mathrm{ft}^{2}$ total foor space, are considered storage. Figure 2.6 is a simplified building plan.

Building heat is supplied with three small ceiling-mounted heaters and cooled with two $24,000-B T U$, wallmounted air conditioning units. No forced air ventilation is provided. Building services include water supply, PS, and electrical (112.5 kVA main transformer). Safety/emergency equipment installed in the building includes an eyewash station and fire extinguishers.

\subsubsection{The 331G Building}

The Interim Tissue Repository (331G Building) in the past has provided research capabilities for conducting radioactive tracer studies using animals, biota, vegetation, and soils. The building was vacated and cleaned in 1999 and all ventilation was shut down. It is currently used to conduct research for development and to evaluate the pertormance of radioactive materials detectors. The detectors are tested for range and effectiveness. The building is actually used as a storage area for the electronics and the radioactive sealed source. The equipment and the source are moved exterior of the building when in use.

The $331 \mathrm{G}$ Building is a 60 -ft by 20 -ft concrete block structure on concrete slab located to the extreme southeast of the 331 Building. It was originally built to house laboratory animals (primarily swine) while they were giving birth. Almost all of the $1,200 \mathrm{ft}^{2}$ are considered dry laboratory.

Heating and cooling is provided by a heat pump which heats and cools the building through a looped systern of ducts which are filtered by HEPA filters. The building also has normal power, process water and a wet pipe fire sprinkler system. Trenches with drains connected to the process sewer are also in the building, but the drains have been plugged.

The $331 \mathrm{G}$ Building has two emission points and both are currently inactive. When the building ventilation system was operational, ventilation from a laboratory fume hood was exhausted through a roof stack; and, the balance of the $331 \mathrm{G}$ room air was exhausted through a stack located north of the facility. A single HEPA filter was installed at each stack. Figure 2.7 is a simplified drawing of the ventilation system.

\subsubsection{The 331H Building}

In the Aerosol Wind Tunnel Research Facility (331H Building), research is conducted to evaluate the effects and changes in plants, animals, and the surface geologic materials occurring as a result of airborne deposition of windblown materials, chemical constituents, or wind erosion and the transport, fate, and effects of biological constituents (e.g., bacteria, fungi, pollen). The facility houses a wind tunnel, associated measurement equipment, and a lab area to perform these studies. 


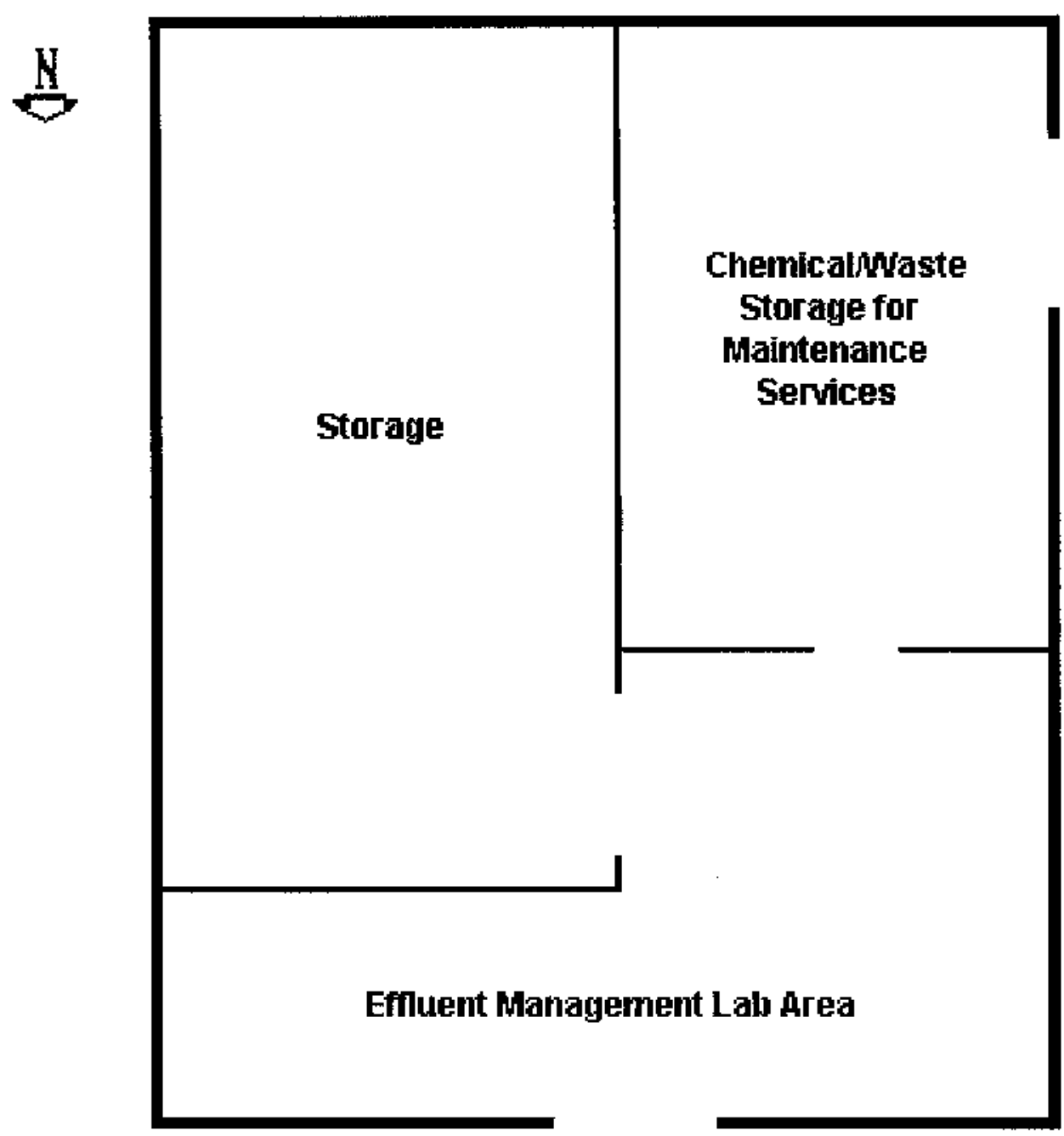

Figure 2.6. 331D Simplified Building Plan

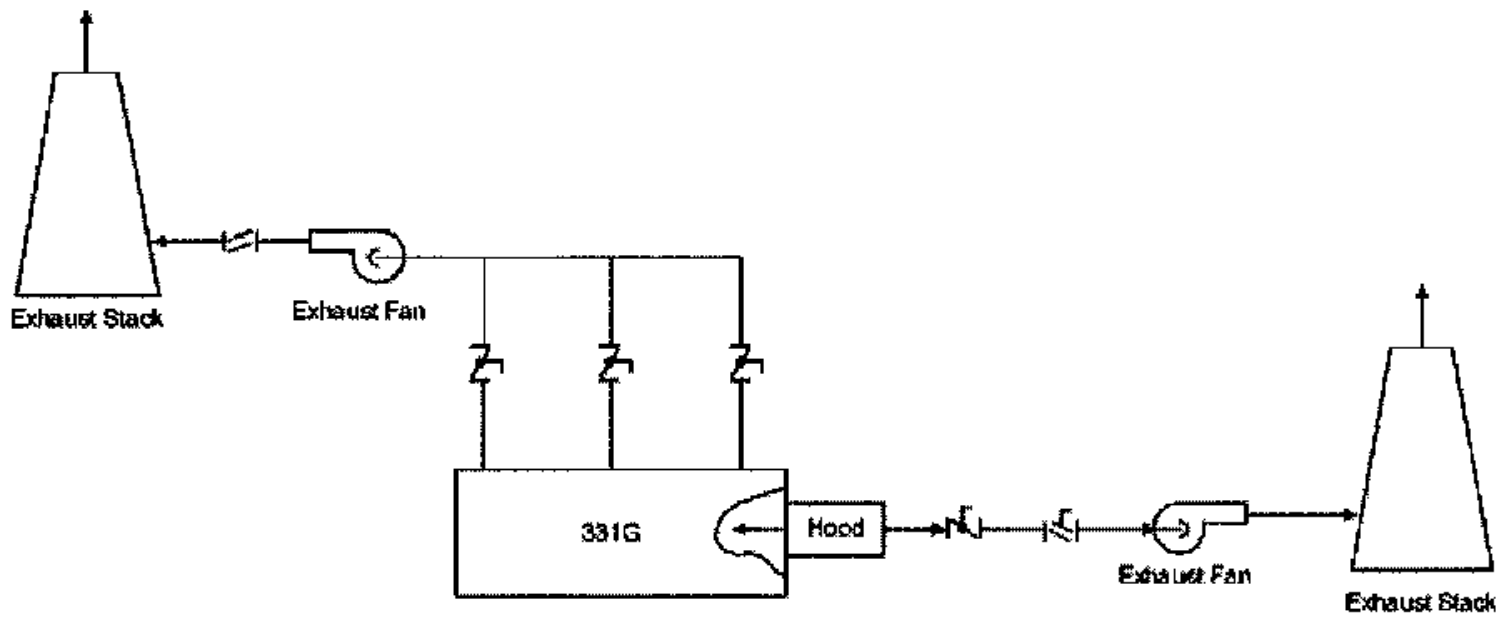

socatros $x$

Figure 2.7. 331G Simplified Ventilation Diagram 


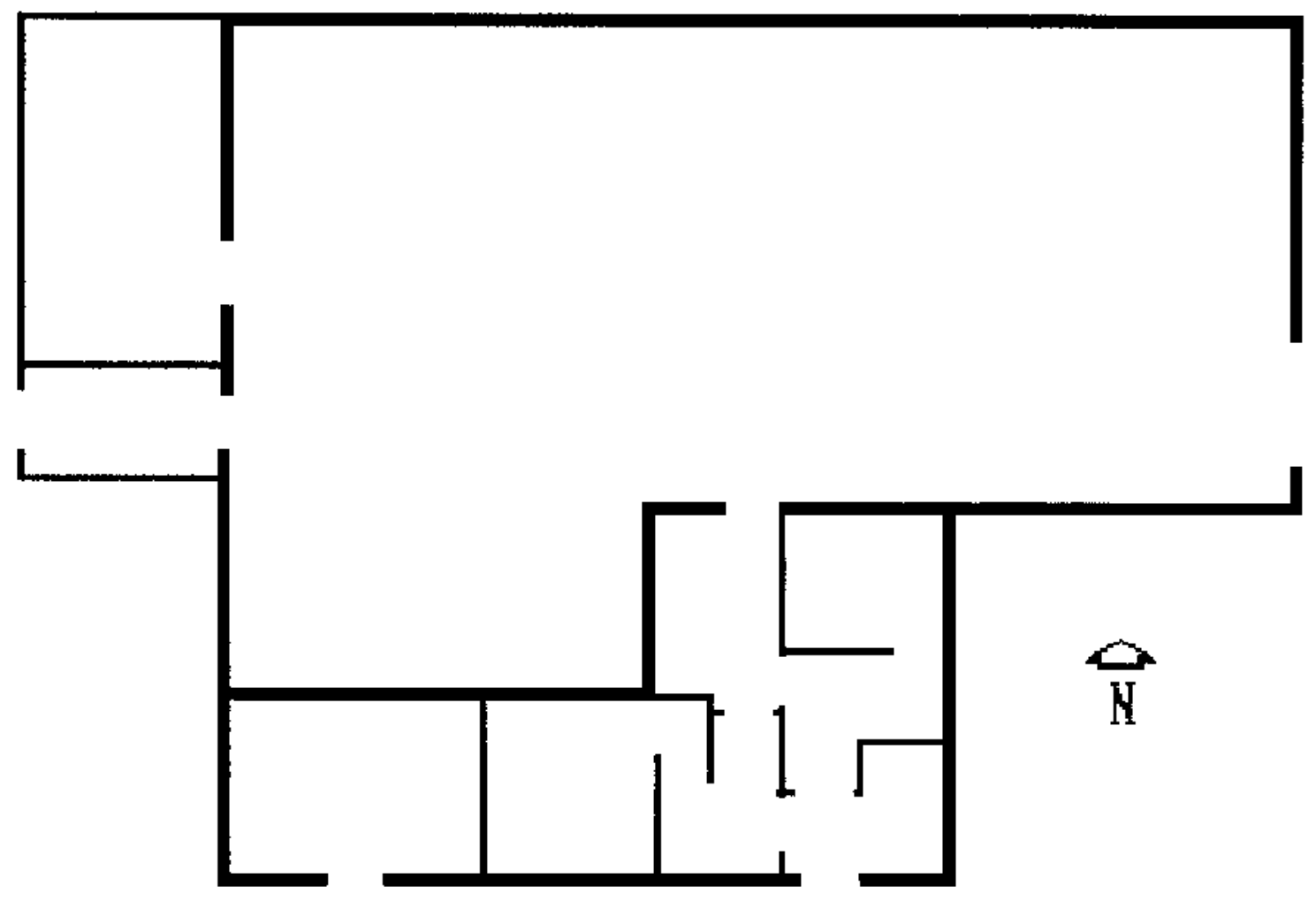

Figure 2.8. $331 \mathrm{H}$ Simplified Building Diagram

The $331 \mathrm{H}$ Building is a one-story concrete block structure on concrete foundations and a concrete slab southeast of the 331 Building (see Figure 2.8). The building has a flat, built-up roof covered with gravel. A metal lean-to is attached to the northwest corner of the building to provide additional research space. A little over half of the $3,600-\mathrm{ft}^{2}$ floor space is considered dry or wet laboratory; the remainder is considered common space.

Building heat is supplied with electric resistant heat coils and a ceiling-mounted electric space heater. The building is cooled with a 25 -ton air-cooled chiller. Outside air is drawn into the building through a pad-mounted air handler and exhausted to a stack. The wind tunnel draws air from the room and exhausts it with the room exhaust to the stack. Building services include compressed air, laboratory vacuum, process water, sanitary sewer, PS, and electrical (150 kVA main transformer plus $55 \mathrm{~kW}$ propane-fueled emergency generator). Safety/emergency equipment installed in the building includes safety shower \& eye wash stations, fire extinguishers, fire alarm, and suppression systems.

\subsection{Source Term Definition and Description}

The characteristics of releases that could contribute to each effluent stream during normal operating and upset conditions are described in this section. Unconfined contact with ventilation air or unrestricted flow path to a sewer is the only prerequisite for an inventory to contribute a source term to an effluent stream. Thus, all "passive" inventories stored in open containers, as well as those undergoing sparging, boiling, pouring, and other "active" processes, can potentially produce gas or aerosol source terms. The following subsections discuss potential source terms under normal and upset ${ }^{(\mathrm{al})}$ conditions.

\section{Normal Operations}

(a) The Environmental Regulatory Guide for Radiological Effluent Monitoring and Environmental Surveillance (U.S. Department of Energy 1991) states that "provislons for monitoring of alrborne emisslons during accldent situations should" be considered." The term "upsets" is used in this document to refer to accidents that might be expected to occur in a facility and for which monitoring should be considered. 
The types of operations performed in each of the 331 Complex facilities are described in Section 2.1. For the 331 Building, these operations primarily include laboratory research experiments involving soils, plants, animals, microorganisms, and solutions. Air and liquid effluents from these activities could occur from storage and handling, sample preparation, experiments, and use of instrumentation. These emissions are considered small compared to pilot-scale or full-scale processes and can contain a variety of chemical or radioactive components.

A risk evaluation is performed before starting new research projects. Part of this evaluation is to identify any environmental issues, including the release of hazardous, toxic, or radioactive effluents. At the evaluation stage, a determination is made on the need for additional effluent controls and for a notice of construction (NOC) for air emissions that may fall outside of the facility-permitted operations. For expanded or modified research projects, the Standards-Based Management System (SBMS) ${ }^{\text {(a) }}$ Subject Area, Airborne Emissions (SBMS, Airborne Emissions), provides requirements and guidance on determining whether additional controls or notification is required for airborne emissions. NOCs are maintained on a web site by PNNL Effluent Management and linked to Facility Use Agreements. Liquid effluents may also be considered before project start up if the effluents pose special challenges. However, the disposal of liquid effluents is generally determined using a discharge approval process after the wastewater has been generated.

Activities having a potential to emit radioactive materials are performed in laboratories provided with HEPA filtration that exhaust to the 331 main stack. Under normal operations, these emissions are continuously sampled at the main stack and analyzed for total alpha and total beta activity. Activities involving chemicals are also performed in laboratories generally equipped with fume hoods and sinks. Air chemical emissions are primarily exhausted from the main stack, but may also be exhausted via other laboratory emission points. The 331 Facility operates under the Hanford Site Air Operating Permit for chemical and radionuclide air emissions. Sampling or monitoring of chemical air emissions is not required for any of the 331 Complex facilities.

Under normal operating conditions, the SNS only receives effluent from the restrooms, water fountains, lunchrooms, and change rooms. No radioactive or hazardous chemical source terms are normally released through this pathway. The PS, which serves laboratory areas, normally does not contain radioactive material or regulated hazardous material. Laboratory-generated, liquid wastes undergo a discharge approval process before discharge to the PS.

The current normal operations do not call for monitoring or sampling the 331 Complex SNS or PS effluent. However, the PS is equipped with a monitoring/sampling system to investigate or characterize discharges trom the building when needed. The SNS can be sampled with a portable sampling system if needed.

The 331 Building aquaculture system serves the aquatics laboratory in the 331 Building. Discharges to this system are limited to pollutants normally found in fish-hatchery discharges. Chemicals used for experimental purposes are not discharged. The aquaculture system discharges to the Columbia River and was included as a monitored outfall under the Hanford Site NPDES permit until 1999. When the permit was re-issued in 1999, the aquaculture outfall was exempted based upon a determination that the operation is well under the production thresholds established for aquatic animal production facilities specified in 40 CFR 122, Appendix C. PNNL continues to monitor the discharge as a best management practice under an agreement with DOE/RL.

The 331 Building is the primary source-term contributor to effluent pathways from the 331 Complex. Other 331 Complex support buildings contribute little or no effluent discharges. The $331 \mathrm{C}$ Building is used primarily for storage and does not have any air or liquid effluents under normal operations. Similarly, activities in the 3310 Building are primarily storage, although some insignificant quantities of liquid effluents may be generated from the Effluent-Management Support Laboratory. Research work in $331 \mathrm{G}$ and $331 \mathrm{H}$ may also generate small quantities of air or liquid effluents under normal operations. The

(a) SBMS provides staff with Laboratory-wide standards, procedures, and guidelines for the work they perform. The Laboratory develops standards, procedures, and guidelines based on an evaluation of extemal requirements documents, including orders, directives, and federal, state and local laws, as well as Battelle policy. 
liquid effluent discharge approval process is followed for liquid effluents, and no sampling is required for airborne emissions.

\section{Upset Conditions}

Section 3.3.2 discusses upset conditions that have been classified as off-normal or unusual occurrences. Upset conditions that could affect air or liquid effluents are primarily spills of hazardous materials. Although some air emissions are generated from spills, they are minor because chemicals are generaliy handled In small quantities in the research laboratories; and, only a small fraction of the material spilled is made airborne (unless the chemical is extremely volatile). The greater environmental hazard from spills is the potential for release to a sewer system. An SBMS Subject Area (SBMS, Working With Chemicals) gives PNNL. staff requirements for training and for responding to a spill. Another Subject Area (SBMS, Managing Liquid Effluents) gives requirements on labeling liquid-effluent access points. Liquid-effluent monitoring is performed, as needed, to respond to spills.

Upset conditions can also disrupt facility ventilation. As shown in Section 3.3.2, power outages sometimes resulting in loss of ventilation have occurred. Also, radiological air sampling-system equipment may fail, disrupting the effluent measurements. Interruptions in the required continuous sampling for the 331 Building are minimized by maintaining critical backup components and providing frequent inspections of the sampling system. The effect of interruptions or other sampling concerns are documented and correction factors determined by Effluent Management when necessary. The other 331 Complex facilities $(331 \mathrm{C}, 331 \mathrm{D}, 331 \mathrm{G}$, and $331 \mathrm{H}$ ) are not required to be sampled, so ventilation upsets in these facilities do not affect air-emission sampling.

Sampling for liquid effluents is periodic for the 331 Building, and loss of power or sampling equipment malfunctions are not considered critical. The sampling period can be adjusted or a discrepancy report completed to identify and correct for the effect on the liquid effluent measurements taken. No air- or liquid-effluent sampling is required for the other 331 Complex facilities. $^{a}$

\subsubsection{Chemical}

Chemical storage and usage are well dispersed throughout the laboratory spaces of the 331 Complex and consist primarily of small-volume chemicals and standards used in conducting laboratory experiments with some larger volumes. Appendix B provides a summary of the quantities of hazardous chemicals with an RQ in the 331 Complex. Most of these chemicals are distributed throughout several laboratories. All chemicals within the facility are inventoried and tracked via the Chemical Management System (CMS) (SBMS, Working with Chemicals). A few chemicals in the facility exceed the RQ specified in EPA (1997) and are listed in Appendix B.

Many of the laboratories contain satellite accumulation areas for liquid and solid hazardous wastes. An active inventory of the waste contents is maintalned in the satellite areas. Llquid and solid wastes are disposed of in accordance with guidelines described in the SBMS (SBMS, Managing Liquid Effluents and Managing Waste).

\subsubsection{Radionuclide}

Radioactive-material storage and usage are dispersed throughout the 331 Building and include a large number of isotopes. These materials are found in several forms, including solid, liquid, particulate, and gas. Some of these materials may also be heated during testing, producing vapors. No radioactive materials are in $331 \mathrm{C}$ and $331 \mathrm{D} ; 331 \mathrm{G}$ and $331 \mathrm{H}$ have sealed sources only.

A current inventory for each building is assessed annually to determine radiological air-emission sampling requirements. The inventory list is a combination of the following three lists:

\footnotetext{
${ }^{2}$ The 300 Area Treated Effluent Disposal Facility samples and monitors the combined 300 Area stream at the Influent to the plant. 
- Part 1 - Inventory estimates provided by 331 staff for any radionuclide material that is not included in the Part 2 or Part 3 inventories

- Part 2 - Composite Radioactive Material Inventory, which contains data on sealed sources that are assigned to custodians and accounted for by PNNL Health and Safety Department

- Part 3 - Nuclear Materials Inventory, which is the inventory of special nuclear material that is maintained in a Material Balance Area (MBA) and assigned to an MBA custodian.

The assessment methodology is documented in Ballinger et al. (2001). Appendix A provides information on the types of radionuclides found in each facility in the 331 Complex.

\subsection{Identification of Effluent Pathways}

Effluent pathways and their facility points-of-discharge of liquid and airborne effluents from the 331 Complex are described in the following sections.

The term "point-of-discharge," as used in this chapter, refers to the point at which the effluent leaves PNNL control. For airborne emissions, the discharge point coincides with the point of effluent entry into the uncontrolled environment. Thus, "discharges" of airborne emissions must comply with DOE, U.S. Environmental Protection Agency (EPA), and Washington State Department of Health (WDOH) emission control and monitoring requirements. The aquaculture system, which discharges into the Columbia River, also enters into the environment when it leaves PNNL control. Aquaculture discharges are exempted from E.PA NPDES requirements but are sampled by PNNL as a best management practice. SNS and PS liquid effluents originating in the 331 Facility, on the other hand, remain in a controlled systern at the "point-of-discharge." At these points, the responsibility for the effluent stream, including its ultimate disposition, passes from PNNL to the site-operations contractor, Fluor Hanford. As such, they are responsible for monitoring and controlling environmental discharges of liquid effluents from these systems. However, PNNL is responsible for characterizing effluents originating in its facilities and for exercising appropriate control over these effluent sources. Therefore, PS sampling and monitoring capabilities are maintained at the 331 Complex to use when needed to characterize or investigate liquid effluents from these systems.

The 331 Complex produces both liquid and gaseous effluent strearns, which are generated in the buildings rather than being pass-throughs from other facilities. The effluent streams during normal and shutdown operations include three sewer systems and individual airborne emission points from 331, $331 \mathrm{G}$, and $331 \mathrm{H}$. The $331 \mathrm{C}$ and 331D Buildings have no forced-air ventilation systems, so airborne emissions from these facilities are considered fugitive emissions.

\subsubsection{Gaseous and Aerosol Emission Pathways}

The 331 Building exhaust system diagrams can be found in the schematics in Appendix D. The detailed drawings were prepared in 1998 and have been identified as "Key drawings." Any facility modification that changes building flow paths must 1) receive prior concurrence of the building manager and 2) update the appropriate drawing before project close-out. The PNNL SBMS Subject Area "Creating or Modifying Engineering Calculations, Drawings, and Specifications" (SBMS, Creating or Modifying Engineering Calculations, Drawings, and Specifications) gives the requirements for controlling facility modifications.

As shown in the Appendix D drawings, the 331 Building is complex with multiple ventilation systems. The main system has four supply fans that operate two at a time, with two operating and two on standby. One of the operating tans provides $100 \%$ outside air, and the other provides some recirculated air from office areas and lab room exhausts. Supply air is drawn through office and laboratory areas and exhausted through the main system ductwork to a rooftop stack. Gloveboxes, fume hoods, and chambers obtain supply air from the surrounding rooms and may exhaust through single or double HEPA filters before exiting the stack.

The animal ventilation system is supplied by two fans separate from the main system. One of the fans is operated at a time and draws $100 \%$ outside air. Laboratory areas served by this system are all on the 
first floor and include several rooms on the west end of the building and most of the north wing. Exhaust air is unfiltered and emitted through a separate stack.

Another exhaust system was originally installed for radon inhalation research, but the research was never initiated due to funding changes. This system serves the labs on the extreme west end of the building and has its own supply and exhaust system. The exhaust is not filtered and exits a roof top stack. The office wing on the northeast side of the building also has an independent ventilation system with heat pumps supplying heating and cooling.

When operational, the $331 \mathrm{G}$ Building obtained supply air from a supply fan that drew in outside air. A fume hood inside the building drew in room air and exhausted through a HEPA filter to the roof. Building air was also exhausted through a HEPA filter, but through a separate stack. This system is currently inactive. Figure 2.8 is a schematic.

The $331 \mathrm{H}$ Building ventilation system draws air in from the outside and exhausts it through a stack. Ventilation for the wind tunnel is provided from the room air and exhausted to the room air ducting.

\subsubsection{Liquid Effluent Pathways}

Liquids effluents are discharged from the 331 Complex facilities via three primary liquid-waste systems: the SNS, the PS, and the aquaculture system. The 331C Building does not have access to any of the sewer systems.

\section{Sanitary Sewer}

The SNS receives effluent from only the restrooms, lunchroom, change rooms, some cooling processes, and other water uses in which no contamination is believed to be possible. Under normal operating conditions, no regulated materials are present in the SNS effluent. The sanitary wastewater is discharged into the 300-Area SNS, operated by Fluor Hanford under contract with DOE. The 300-Area SNS discharges to the City of Richland Publicly-Owned Treatment Works (POTW) under a contract agreement between DOE and the City. Both the 331 and $331 \mathrm{H}$ Buildings have access to the SNS.

\section{Process Sewer}

The PS receives process wastewater, such as equipment cooling water, effluent from cage washers, and laboratory wastewater from the 331 Complex facilities. The PS discharges to the 300-Area PS System that flows to the Treated Effluent Disposal Facility (TEDF) before being discharged to the Columbia River. The 331, 331D, and 331H Buildings have access to the PS. PS drains in the 331G Building have been plugged. Figure 2.9 is a schematic of the 300 -Area PS.

\section{Aquaculture System}

The aquaculture system was developed to support aquaculture research in the 331 Building. Only the 331 Building is served by this system. The Aquatics Laboratory uses both river- and well-water sources for supplying water for fish-rearing activities. Effluents are discharged to the Columbia River. In addition to aquaculture operations, storm water from the southern half of the 331 Building rooftop also contributes to the outfall discharges. Figure 2.10 is a schematic of the aquaculture discharge system. 


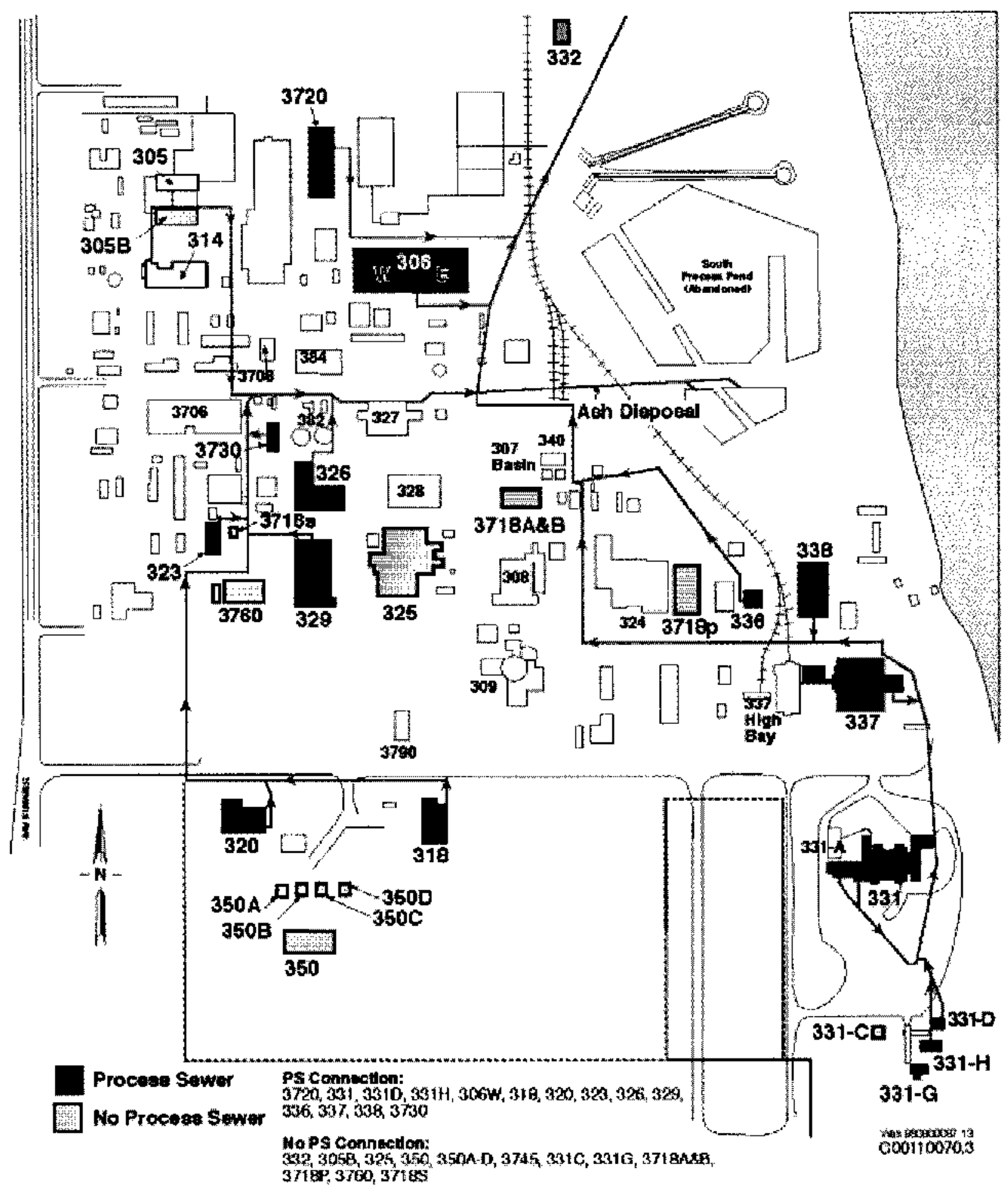

Flgure 2.9. 300 Area Process Sewer 


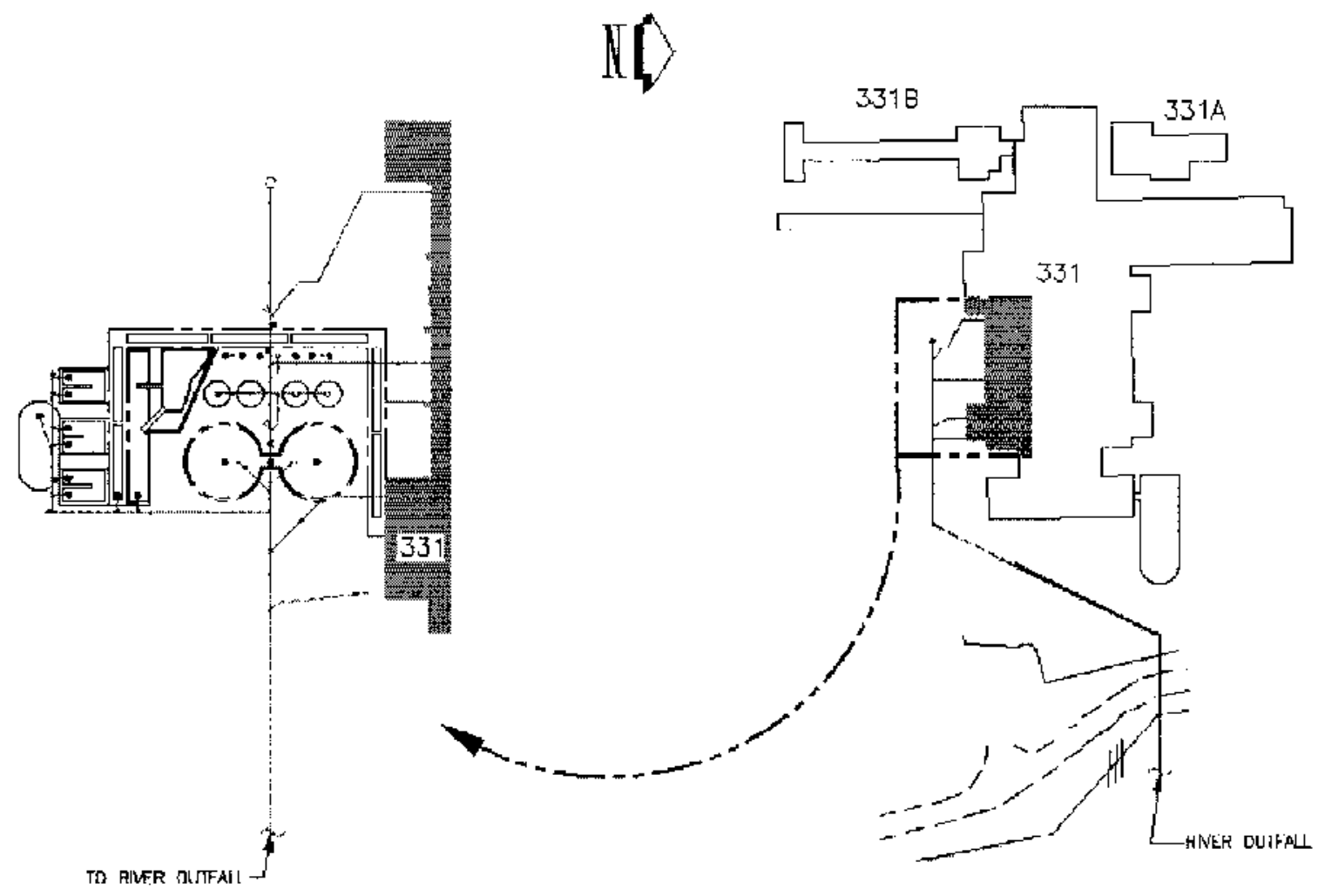

Figure 2.10. Schematic of Aquaculture Discharge System 


\subsection{Rationale and Design Criteria for Monitoring}

This section discusses design criteria for the 331 Complex Effluent Measurement Program. Criteria are established to verify that effluent measurements are performed according to applicable regulations and guidance and are appropriate for existing facility operations.

In this section, the terms "sampling" and "monitoring" are used to distinguish between two types of airborne-emissions measurement processes:

- Sampling" refers to collecting a representative portion of the emission over a period of time, with subsequent analysis for constituents of interest. "Sampling" is an "after-the-fact" measurement.

- "Monitoring", on the other hand, is measuring radionuclide emission rates by means of a detector located in the sample stream. "Monitoring" is a "real-time" measurement.

Airborne and liquid-effluent sampling is performed to demonstrate compliance with emission standards, to identify emission trends, and to provide evidence regarding the effectiveness of emission-control systems. Effluent sampling may also be performed to characterize waste streams or investigate discharges of concern.

Effluent stream monitoring is performed as a means to provide timely indication of a significant change in emission rate. Although not required for compliance, a liquid-effluent monitoring system is provided in the 331 Complex at a location downstream of the combined PS discharges from all 331 Complex Buildings. This system is used as a tool to investigate potential problematic discharges. In addition, the 331 Aquaculture System is monitored as a best management practice even though the system was exempted in 1999 from the Hanford Site-Wide NPDES Permit based upon a determination that the operation is well under the production thresholds established for aquatic animal production facilities.

Currently, radiological air sampling is required at the 331 main stack only. The sections below give the bases, criteria, and descriptions of compliance sampling systems and operations.

\subsection{Basis for Design Criteria}

The following regulations, DOE Orders, and guidance were considered in effluent sampling and monitoring system design and operation:

Regulations on Standards of Perfomance for New Stationary Sources, Appendix A: Reference Methods. Environmental Protection Agency, U.S. Code of Federal Regulations, 40 CFR 60 (EPA 1971).

National Emission Standards for Hazardous Air Pollutants. Environmental Protection Agency, U.S. Code of Federal Regulations, 40 CFR 61 (EPA 1990).

Hanford Site Air Operating Permit \#00-05-006. Washington State Department of Ecology.

Radiation Protection - Air Emissions. Washington Department of Health. Washington Administrative Code, WAC 246-247 (WAC 1994).

General Environmental Protection Program. U.S. Department of Energy. DOE 5400.1 (DOE 1988).

Fadiation Protection of the Public and the Environment. U.S. Department of Energy. DOE 5400.5 (DOE 1990).

General Design Criteria. U.S. Department of Energy. DOE 6430.1A (DOE 1987).

Environmental Regulatory Guide for Radiological Effluent Monitoring and Environmental Surveillance. U.S. Department of Energy. DOE/EH-0173T (DOE 1991). 
Guide to Sampling Airborne Radioactive Materials in Nuclear Facilities. American National Standards institute ANSI N13.1-1969 (ANSI 1969).

Sampling and Monitoring Releases of Airborne Radioactive Substances From the Stacks and Ducts of Nuclear Facilities. American National Standards Institute ANSI N13.1-1999 (ANSI 1999).

Specifications and Performance of Onsite Instrumentation for Continuously Monitoring Radioactivity in Effluenfs. American National Standards Institute ANSI N42.18 1980 (ANSI 1980).

The following additional requirements for sampling/monitoring at the 331 Facility are prescribed in PNNL. operational and programmatic documents:

Standards-Based Management System Subject Area Airbome Emissions. Pacific Northwest National Laboratory, Richland, Washington. (SBMS, Airborne Emissions)

Standards-Based Management System Subject Area Creating or Modifying Engineering Calculations, Drawings, and Specifications. Pacific Northwest National Laboratory, Richland, Washington. (SBMS, Creating or Modifying Engineering Calculations, Drawings, and Specifications).

Standards-Based Management System Subject Area Managing Liquid Effluents. Pacific Northwest National Laboratory, Richland, Washington. (SBMS, Managing Liquid Effluents).

Standards-Based Management System Subject Area Managing Waste. Pacific Northwest National Laboratory, Richland, Washington. (SBMS, Managing Waste).

Standards-Based Management System Subject Area Working With Chemicals. Pacific Northwest National Laboratory, Richland, Washington. (SBMS, Working With Chemicals).

\subsection{Criteria for Radiological Air Emission Sampling and Monitoring}

Airborne radionuclide emission points at PNNL are classified as either "major" or "minor." These two categories are defined as follows:

Major emission points those where radionuclide emissions could cause an offsite emission dose $(\mathrm{OED})^{\text {(a) }}$ of $0.1 \mathrm{mrem} / \mathrm{yr}$ or greater, if emission controls were not applied. Major emission points are sampled according to requirements in Subpart $\mathrm{H}$ of 40 CFR 61 (EPA, 1990).

Minor emission points those that potentially could release radionuclides, but not at the levels of a "major" point.

The 331 Building main stack is considered a "major" emission point according to the criteria above. Continuous sampling for radiological air emissions is required. Emission points from $331 \mathrm{H}$ and $331 \mathrm{G}$ are considered "minor" and are currently inactive or de-registered. The 331C and 331D Buildings do not have a potential to release radionuclides.

\subsubsection{Sampling System Performance Criteria}

Sampling at each major emission point shall be capable of detecting an annual radionuclide release quantity resulting in a total OED of $0.01 \mathrm{mrem} / \mathrm{yr}$ (DOE 1991).

(a) The annual OED is the maximum committed effective dose equivalent that could be expected to be received by an offsite individual from facility airborne radionuclide emissions if the facility was operated without any HEPA filtration or other emission controls. The method for calculating the OED consists of identifying the radionuclide inventory potentially available for release, multiplying this by a fractional release value, and multiplying this product times an emission dose factor calculated by the EPA Clean Air Act compliance code CAP-88. Ballinger et al. (2001) provides additional discussion of this assessment method. 
All radionuclides anticipated to contribute greater than $10 \%$ of the potential to emit (PTE) from the sampled emission point shall be accounted for either by direct analysis or by inference from an indicator measurement. The measurement for individual radionuclides shall be capable of detecting an annual radionuclide release quantity resulting in a total OED of $0.01 \mathrm{mrem} / \mathrm{yr}$.

Biases in emission measurements arising from the sample collection and analysis process shall be minimized through the judicious application of design and operation practices according to American National Standards Institute (ANSI) (ANSI N13.1 1969, and 1999) and DOE/EH-0173T (DOE, 1991).

\subsubsection{Sampling System Design Criteria}

Samplers shall be located according to criteria in 40 CFR 60 (EPA, 1971) Method 1 in Appendix A. Method 1 states that

"Sampling or velocity measurement is performed at a site located at least eight stack or duct diameters downstream and two diameters upstream from any flow disturbance such as a bend, expansion, or contraction in the stack, or from a visible flame."

However, the method also states that,

"... if necessary, an alternative location may be selected, at a position at least two stack or duct diameters downstream and a half diameter upstream from any flow disturbance."

For minor stack sampling, this criterion is desired, but not required.

Air emission samplers should be designed to maximize the sensitivity of the sample, considering the capacity of the collection media, radioactive decay, and sample-analysis costs.

Representative samples shall be withdrawn on a continuous basis at the sampling site following the guidance in ANSI (1969), Appendix A, Section A3.2, which recommends a minimum of six extraction points for the 331 Facility main stack (EP-331-01-V). Furthermore, ANSI N13.1(1969) recommends that each withdrawal point within a cylindrical stack be centered in an annular area of size equal to the cross sectional area divided by the number of probes. Withdrawal points may be on a single traverse or spaced to obtain samples from the total cross section. Additional design criteria for particulate and gaseous radionuclides are specified by ANSI N13.1 (1969) and DOE (1991).

\subsubsection{Sampling System Operation}

PNNL's Effluent Management Group maintains sampling-system, configuration drawings for all emission point radionuclide air sampling systems. This includes calculations of sampling system efficiencies particle sizes of 1 micron and 10 microns. A 1 micron particle size is assumed under normal operating conditions because most radionuclide air emissions are HEPA filtered.

Sampling-system operating criteria are based on regulations and guidance documents listed in Section 3.1.

Sampling is performed to quantify emissions over a calendar year. Sample-collection frequency is based on the need for unbiased samples while maximizing sensitivity and minimizing analytical costs. The period of sample collection, therefore, should be as long as possible, considering the half-life of the radionuclide, the capacity of the collection media, and the need for timely return of sampling data.

Samples are analyzed in the laboratory according to procedures required by Appendix $B$, Method 114, "Test Methods for Measuring Radionuclide Emissions from Stationary Sources," in 40 CFR 61 (EPA, 1973). Radioanalytical laboratories analyze samples according to prescribed statements of work. Work statements specify analytical performance requirements, including minimum detectable activity (MDA), turnaround time, reporting requirements, quality control (QC) requirements, and sample handling. 
Sampling performance criteria in Section 3.2.1 specify an emission detection level of $0.01-\mathrm{mrem} / \mathrm{yr}$ OED. The analytical MDA required to meet this criterion depends on a combination of factors, including sample size, stack flow rate, collection period, radionuclide half-life, and radionuclide emission dose factor.

Historically, laboratory analysis of particulate emission samples from the 331 Complex emission points that were sampled consisted of total-activity (total alpha, total beta) measurements. Totalactivity measurements were performed because:

- emissions were historically very low

- potentially significant constituents of the emission stream were known

- the gross-activity measurement was nondestructive; radionuclide-specific measurement could be performed on the sample if gross-activity measurements showed a potentially significant release quantity.

When gross-activity measurements were used for assessing offsite dose, dose factors for the most restrictive radionuclide potentially contributing $10 \%$ or more to the annual emission dose were applied.

All of the 331 Complex facility emission points were either considered "minor" or had no potential to emit radionuclides until 1997 when a scheduled move of additional research projects into the 331 Building increased the inventory such that the main emission point from 331 was upgraded to "major." As of 1998, airborne particulate samples for the 331 Building major emission point have been analyzed for several specific radionuclides in addition to the gross-activity measurements. These specific analyses included those radionuclides potentially contributing $10 \%$ of the PTE for the building.

Exhaust-stream flow rates at sampling locations are measured using 40 CFR 60 Method 2 (EPA 1971). Flow-rate measurements are performed on a periodic basis for major emission points as well as following modifications to the exhaust system that could be expected to cause the average exhaust rate to differ by $\pm 10 \%$ from the previously measured rate.

Air-emission samplers should be designed to maximize the sensitivity of the sample, considering the capacity of the collection media, radioactive decay, and sample-analysis costs.

Isokinetic sampling is required for major emission points where particulate emissions are expected. ${ }^{\text {(a) }}$

Under most operating conditions, isokinetic sampling can be adequately accomplished by operating the sampler so that 1) sample probes are aligned axially with the stack and point into the direction of stack flow, and 2) sample nozzle inlet velocity is maintained within a factor of two of the mean stack-exhaust velocity at the sample location. (b) $^{\text {(b) }}$

At the "major" emission points, samplers are operated continuously, except during planned sampler maintenance or testing outages. When continuous sampling is required, the loss of sampling capability is limited to $24 \mathrm{~h} / \mathrm{month}$. If this limit is exceeded, special interim sampling is provided, or pertinent facility operations are shut down.

\subsection{Historical Monitoring/Sampling Data for Effluent Streams}

The 331 Facility was built in 1970 for biological and botanical research. Associated buildings (331A to 331J) were constructed during the 1970 s for various support functions. Some of the effluent streams

(a) Emissions from the 331 main stack are filtered using HEPA filters before discharge. Unless failure of a HEPA filter system occurs (an unlikely event), particle emissions are expected to be relatively small. Based on criteria in ANSI (1969), isokinetic sampling for systems emitting particles less than $5-\mu \mathrm{m}$ aerodynamic diameter is not necessary. DOE (1991) recommends isokinetic sampling when particles are greater than $0.5-\mu m$ aerodynamic median diameter

(b) From Table C1 in ANSI (1969), a sampler operating at an inlet velocity of within a factor of two of the stack velocity will have a particle interception bias of $14 \%$ for a $4-\mu \mathrm{m}$ aerodynamic equivalent diameter particulate emission.

Issued: $10 / 2002$

Supersedes: PNNL-12158

PNNL-12158, Rev. 1: Rationale and Design Criteria for Monitoring 
from the 331 and support buildings have been sampled and monitored over the history of operations. Information from historical sampling and monitoring is provided in this section to aid in providing a basis for future monitoring needs. A description of historic sampling and monitoring data under normal operating conditions for air and liquid effluent streams is given in Section 3.3.1. Estimates of the types of releases and release pathways experienced during facility operations under upset conditions are given in Section 3.3.2.

\subsubsection{Normal Conditions}

Some of the air and liquid-effluent streams have been sampled and monitored since the 331 Complex facilities started operations. The types and locations of sampling and monitoring and analytical methods under normal operations are described in this section. Discussion is generally limited to the past 10 years (1991 through 2001) because this period is the most relevant to future operations and monitoring needs.

\subsubsection{Radionuclide Air Emission Sampling}

Effluent air from the 331 Building main exhaust and from $331 \mathrm{H}$ has been sampled and monitored downstream of the final HEPA filters for radioactive particles. Sampling for particulate gross-alpha and beta has been provided by a record sampler from 1991 - 1997. During this time, both the 331 main stack and the $331 \mathrm{H}$ stack were considered minor emission points for radioactive air emission sampling ${ }^{\text {(a) }}$.

Sampling of the $331 \mathrm{H}$ stack was discontinued in 1997 because the building radioactive inventory consisted solely of sealed sources. In 1998, the radionuclide inventory in the 331 Building was increased due to the addition of research projects moved from other facilities. The increased inventory resulted in an upgrade of the main stack to "major" status, and continuous sampling was initiated in April of 1997 in preparation for the increased inventory. In addition, samples were composited and isotopic analysis performed for radionuclides contributing $>10 \%$ of the potential-to-emit for the building. Estimated emissions calculated from the sampling data from 1991 to 1997 are shown in Table 3.1. Emissions from 1998 - 2001 were obtained from the Radionuclide Air Emissions Report for the Hanford Site for the listed calendar years and are presented in Table 3.2.

Table 3.1. Estimated Annual Emissions from 331 and 331H (1991-1997)

\begin{tabular}{|l|c|c|c|c|}
\hline \multirow{2}{*}{ Year } & \multicolumn{2}{|c|}{331} & \multicolumn{2}{c|}{ 331H } \\
\cline { 2 - 5 } & Gross-Alpha, Cl & Gross-Beta, Cl & Gross-Alpha, Cl & Gross-Beta, Ci \\
\hline 1991 & $3.9 \mathrm{E}-7$ & $4.2 \mathrm{E}-5$ & $2.6 \mathrm{E}-8$ & $1.6 \mathrm{E}-6$ \\
\hline 1992 & ND & $6.6 \mathrm{E}-6$ & ND & $6.3 \mathrm{E}-7$ \\
\hline 1993 & $2.0 \mathrm{E}-7$ & $2.1 \mathrm{E}-6$ & $3.4 \mathrm{E}-8$ & $2.9 \mathrm{E}-7$ \\
\hline 1994 & $1.3 \mathrm{E}-7$ & $3.8 \mathrm{E}-7$ & $9.3 \mathrm{E}-9$ & $1.0 \mathrm{E}-8$ \\
\hline 1995 & $4.1 \mathrm{E}-8$ & $3.5 \mathrm{E}-7$ & $9.3 \mathrm{E}-9$ & $3.6 \mathrm{E}-8$ \\
\hline 1996 & $2.0 \mathrm{E}-7$ & $2.7 \mathrm{E}-6$ & ND & ND \\
\hline 1997 & $2.5 \mathrm{E}-7$ & $2.8 \mathrm{E}-6$ & Not Measured & Not Measured \\
\hline $\begin{array}{l}\text { ND }=\text { Not Detectable } \\
\text { Not Measured - Measurements from 331H were no longer taken in } 1997 \text { because the } \\
\text { radionuclide inventory consisted of sealed sources only. }\end{array}$
\end{tabular}

\subsubsection{Llquid Effluent Sampling and Monitoring}

Liquid waste streams in the 331 Complex facilities have been served by three systems as described in Section 2.3.2. Table 3.3 summarizes the type of historical monitoring/sampling each liquid waste system has had. As noted in the table, historically, 300-Area sanitary liquid waste was sampled at the SNS system just before the waste entered the SNS septic tanks. Before 1997, sanitary wastes were discharged to a 300-Area septic tank/trench system. In 1997, the 300-Area SNS was connected to the City of Richland POTW. The Westinghouse Hanford Company Effluent Report for 300, 400, and

(a) The 331A stack was also sampled prior to 1997, but was decommisioned and taken down in 1997. 
Table 3.2. Estimated Annual Emissions from 331 (1998- 2001)

\begin{tabular}{|c|c|c|c|c|}
\hline Nuclide, $\mathrm{Ci}$ & 1998 & 1999 & 2000 & 2001 \\
\hline${ }^{90} \mathrm{Sr}$ & $\overline{\mathrm{ND}}$ & $6.9 \mathrm{E}-8$ & $2.6 E-8$ & $4.1 \mathrm{E}-8$ \\
\hline${ }^{737} \mathrm{Cs}$ & ND & $\mathrm{ND}$ & ND & ND \\
\hline${ }^{239} \mathrm{Pu}$ & ND & $\overline{N D}$ & $7.7 \mathrm{E}-10$ & ND \\
\hline${ }^{239}+240 \mathrm{Pu}$ & $2.0 \mathrm{E}-8$ & $7.6 \mathrm{E}-8$ & ND & $2.2 \mathrm{E}-9$ \\
\hline${ }^{241} \mathrm{Pu}$ & $\overline{N D}$ & $\overline{N D}$ & ND & ND \\
\hline${ }^{241} \mathrm{Am}$ & $3.7 \mathrm{E}-9$ & ND & $3 . \overline{6 E-9}$ & $2.0 \mathrm{E}-9$ \\
\hline${ }^{243} \mathrm{Am}$ & ND & $\mathrm{ND}$ & ND & ND \\
\hline Unspecified alpha & $2.8 \mathrm{E}-7$ & $2.7 \mathrm{E}-7$ & $1.4 \mathrm{E}-7$ & $6.9 \mathrm{E}-8$ \\
\hline Unspecified beta & $1.0 \mathrm{E}-6$ & $8.6 \mathrm{E}-7$ & $5.2 \mathrm{E}-7$ & 3.7E-7 \\
\hline
\end{tabular}

Table 3.3. Summary of Historical Liquid Monitoring/Sampling

\begin{tabular}{|l|l|}
\hline \multicolumn{1}{|c|}{ System } & \multicolumn{1}{c|}{ Comments } \\
\hline SNS & $\begin{array}{l}\text { No sampling or monitoring at 331 Facilities. Sampled as composite with other } 300 \\
\text { Area SNS before 1997 and sampled as required by contract with City of Richland } \\
\text { POTW after 1997 hook-up. Currently required sampling is performed by the 300 } \\
\text { Area infrastructure contractor. }\end{array}$ \\
\hline PS & $\begin{array}{l}\text { Sampling of 331 PS conducted as part of PNNL's 1994 and 1995 sampling } \\
\text { campaign to characterize liquid wastes for TEDF. System also sampled on an ad- } \\
\text { hoc basis as requested by Fluor Hanford to assist in identifying transient } \\
\text { contaminant conditions. }\end{array}$ \\
\hline Aquaculture & $\begin{array}{l}\text { Sampled as required by NPDES Outfall from 1976 to } 1999 \text { and sampled as a best } \\
\text { management practice from 1999 to the present. }\end{array}$ \\
\hline
\end{tabular}

1100 Area Operations (McCarthy 1990) briefly describes the sampling and analysis program before being connected to the City of Richland POTW. Because this sampling program is not specific to the 331 Complex facilities, its historical data are not reported here.

Historically, the 300 Area PS was discharged to trenches. Samples of the composite liquid waste from all the 300 Area PS lines were taken before the liquid was discharged to the 300 Area process trenches (McCarthy 1990). These sampling data are not specific to the 331 Complex facilities and thus are not included in this report. In December 1994, a treatment facility, the 300 Area TEDF, was brought into operation to replace the trenches. To support TEDF design, PS samples were taken from various locations in the 300 Area in 1989 (Westinghouse Hanford Company 1989). However, no samples were taken specific to the 331 Complex facilities.

PNNL conducted a separate facility-specific sampling campaign in 1994 and 1995 to characterize the waste streams from the primary PNNL research and development (R\&D) facilities. Sampling and analysis for radioactive and non-radioactive constituents occurred at the 331 PS manhole as a result of the campaign. The data are summarized in Table 3.4. Additional details can be found in Thompson et al. (1997). The data show that liquid effluents from the 331 PS have a variety of different constituents. Most of these are in small (parts per billion or $\mu \mathrm{g} / \mathrm{L}$ ) concentrations. However, some samples contained constituents that exceeded the TEDF waste-acceptance criteria. In these cases, it was found that samples taken simultaneously at the end-of-pipe (where the 300 Area PS stream converges and is pumped up to TEDF) did not exceed the waste acceptance criteria.

The aquaculture system outfall was sampled and monitored as required by the NPDES permit from 1976 to 1999. The outfall samples were collected in accordance with the NPDES permit and reported in monthly Discharge Monitoring Reports as required by the permit. Sampling and monitoring measurements were within permit limits. 
Table 3.4. Constituents Detected in Building 331 Samples

\begin{tabular}{|c|c|c|c|c|}
\hline \multirow[b]{2}{*}{ Constituent } & \multirow[b]{2}{*}{ Frequency $^{(b)}$} & \multicolumn{3}{|c|}{ Concentration $(\mu \mathrm{g} / \mathrm{L})^{(a)}$} \\
\hline & & Range & Average & $\begin{array}{c}\text { Standard } \\
\text { Deviation }^{(\mathrm{c})}\end{array}$ \\
\hline \multicolumn{5}{|c|}{ General Chemical Parameters } \\
\hline Alkalinity & $45 / 45$ & $40,000-130,000$ & 68,000 & 20,000 \\
\hline $\begin{array}{l}\text { Chemical Oxygen } \\
\text { Demand }\end{array}$ & $32 / 38$ & $6,000-140,000$ & 22,000 & 24,000 \\
\hline Conductivity & $34 / 34$ & $72-920$ & 250 & 150 \\
\hline $\mathrm{pH}$ & $34 / 34$ & $5.1-8.8$ & 7.6 & 0.85 \\
\hline Total carbon & $38 / 38$ & $14,000-76,000$ & 22,000 & 10,000 \\
\hline Total dissolved solids & $43 / 43$ & $90,000-480,000$ & 140,000 & 62,000 \\
\hline Total organic carbon & $44 / 44$ & $2,000-61,000$ & 6,500 & 9,000 \\
\hline \multicolumn{5}{|c|}{ Ammonia and Anions } \\
\hline Ammonia & $34 / 45$ & $30-1,000$ & 140 & 230 \\
\hline Bromide & $2 / 42$ & $140-200$ & 170 & - \\
\hline Chloride & $43 / 43$ & $3,600-170,000$ & 11,000 & 24,000 \\
\hline Cyanide & $33 / 43$ & $1-70$ & 17 & 20 \\
\hline Fluoride & $43 / 43$ & $300-1,100$ & 640 & 150 \\
\hline Nitrate & $43 / 43$ & $300-33,000$ & 6,100 & 7,900 \\
\hline Nitrite & $2 / 35$ & $110-130$ & 120 & - \\
\hline Phosphate & $31 / 43$ & $210-82,000$ & 7,100 & 15,000 \\
\hline Sulfate & $43 / 43$ & $10,000-48,000$ & 19,000 & 5,800 \\
\hline Sulfides & $12 / 38$ & $200-400$ & 240 & 64 \\
\hline \multicolumn{5}{|c|}{ Metals } \\
\hline Aluminum & $43 / 44$ & $22-630$ & 150 & 160 \\
\hline Arsenic & $5 / 44$ & $2-3$ & 2.4 & 0.5 \\
\hline Barium & $44 / 44$ & $17-48$ & 29 & 6 \\
\hline Beryllium & $1 / 44$ & - & 0.19 & - \\
\hline Cadmium & $2 / 44$ & - & 3.4 & - \\
\hline Calcium & $44 / 44$ & $16,000-43,000$ & 24,000 & 6,300 \\
\hline Chromium & $6 / 44$ & $4.3-22$ & 13 & 8 \\
\hline Gopper & $44 / 44$ & $9.5-930$ & 51 & 140 \\
\hline Iron & $42 / 44$ & $18-460$ & 85 & 78 \\
\hline Lead & $36 / 44$ & $0.6-17$ & 2.5 & 2.8 \\
\hline Magnesium & $44 / 44$ & $3,900-18,000$ & 5,500 & 2,200 \\
\hline Manganese & $35 / 44$ & $1-16$ & 3.4 & 3.3 \\
\hline Mercury & $11 / 44$ & $0.055-0.17$ & 0.096 & 0.036 \\
\hline Nickel & $2 / 44$ & $16-17$ & 17 & - \\
\hline Potassium & $43 / 44$ & $940-12,000$ & 3,400 & 2,500 \\
\hline Selenium & $5 / 44$ & $0.95-2$ & 1.5 & 0.51 \\
\hline Silicon & $2 / 2$ & $3,000-3,200$ & 3,100 & - \\
\hline Silver & $2 / 44$ & $3.6-7.1$ & 5.4 & - \\
\hline Sodium & $44 / 44$ & $3,300-110,000$ & 13,000 & 17,000 \\
\hline Strontium & $3 / 3$ & $93-110$ & 100 & 9 \\
\hline Thallium & $4 / 44$ & $0.58-1.1$ & 0.83 & 0.21 \\
\hline Tin & $5 / 44$ & $24-110$ & 71 & 31 \\
\hline Vanadium & $6 / 44$ & $2-7.8$ & 4.3 & 2.6 \\
\hline Zinc & $44 / 44$ & $22-230$ & 67 & 39 \\
\hline
\end{tabular}




\begin{tabular}{|c|c|c|c|c|}
\hline \multicolumn{5}{|c|}{ Table 3.4 (contd) } \\
\hline \multirow[b]{2}{*}{ Constituent } & \multirow[b]{2}{*}{ Frequency $^{(\mathrm{b})}$} & \multicolumn{3}{|c|}{ Concentration $(\mu \mathrm{g} / \mathrm{L})^{(\mathbf{a})}$} \\
\hline & & Range & Average & \begin{tabular}{|c|} 
Standard \\
Deviation $^{(\mathrm{c})}$
\end{tabular} \\
\hline \multicolumn{5}{|c|}{ Volatile Organic Compounds } \\
\hline 1,1,1-Trichloroethane & $1 / 66$ & - & 2.1 & - \\
\hline 2-Butanone & $3 / 66$ & $51-170$ & 100 & 61 \\
\hline Acetone & $15 / 66$ & $5.6-1800$ & 140 & 460 \\
\hline Acetonitrile & $1 / 26$ & - & 430 & - \\
\hline Bromodichloromethane & $16 / 34$ & $0.5-9.8$ & 2.3 & 2.3 \\
\hline Bromoform & $1 / 34$ & - & 26 & - \\
\hline Chlorobenzene & $1 / 26$ & - & 0.39 & - \\
\hline Chloroform & $66 / 66$ & $3.1-33$ & 11 & 6.5 \\
\hline Dibromochloromethane & $6 / 34$ & $0.7-11$ & 2.7 & 4.1 \\
\hline Ethanol & $5 / 66$ & $8.3-47$ & 21 & 15 \\
\hline Hexone & $4 / 66$ & $1.9-19$ & 11 & 9.2 \\
\hline Isopropyl alcohol & $1 / 66$ & - & 19 & - \\
\hline Methylene chloride & $43 / 66$ & $0.4-4.8$ & 1.2 & 0.9 \\
\hline Tetrahydrofuran & $2 / 66$ & $0.52-3$ & 1.8 & - \\
\hline Toluene & $4 / 66$ & $0.22-0.86$ & 0.53 & 0.26 \\
\hline Trichloroethene & $3 / 66$ & $0.51-0.91$ & 0.77 & 0.23 \\
\hline Xylenes (total) & $3 / 66$ & $1.4-2.4$ & 1.8 & 0.5 \\
\hline \multicolumn{5}{|c|}{ Semivolatile Organic Compounds (Acids/Bases/Neutrals) } \\
\hline Benzyl alcohol & $3 / 15$ & $4.1-34$ & 22 & 16 \\
\hline $\begin{array}{l}\text { Bis(2-ethylhexyl) } \\
\text { phthalate }\end{array}$ & $8 / 46$ & $1-6.4$ & 3.7 & 2.3 \\
\hline Decane & $1 / 32$ & - & 37 & - \\
\hline Di-n-butylphthalate & $4 / 14$ & $2-3.6$ & 2.5 & 0.8 \\
\hline Kerosene & $1 / 14$ & - & 9.5 & - \\
\hline Phenol & $4 / 46$ & $1-4.9$ & 2.5 & 1.8 \\
\hline \multicolumn{5}{|c|}{ Semivolatile Organic Compounds (Pesticides) } \\
\hline $4,4^{\prime}-\mathrm{DDE}$ & $3 / 40$ & $0.0017-0.72$ & 0.24 & 0.41 \\
\hline Aldrin & $1 / 40$ & - & 0.011 & - \\
\hline Alpha-BHC & $3 / 40$ & $0.0036-0.0073$ & 0.0057 & 0.0019 \\
\hline Beta - BHC & $4 / 40$ & $0.0099-0.026$ & 0.017 & 0.0083 \\
\hline Delta $-\mathrm{BHC}$ & $10 / 40$ & $0.0017-0.033$ & 0.011 & 0.0088 \\
\hline Dieldrin & $1 / 40$ & - & 0.0032 & - \\
\hline Endosulfan I & $6 / 40$ & $0.0018-0.005$ & 0.0032 & 0.001 \\
\hline Endrin & $2 / 40$ & $0.0025-0.0066$ & 0.0046 & - \\
\hline Endrin aldehyde & $1 / 40$ & - & 0.012 & - \\
\hline Gamma - BHC (Lindane) & $5 / 40$ & $0.0023-0.0038$ & 0.0029 & 0.0007 \\
\hline Methoxychlor & $1 / 40$ & - & 0.019 & - \\
\hline \multicolumn{5}{|c|}{ Radiological Parameters } \\
\hline Gross-Alpha & $19 / 47$ & $0.91-8.3$ & 3.0 & 0.47 \\
\hline Gross-Beta & $27 / 47$ & $2.1-15$ & 5.2 & 0.58 \\
\hline Tritium & $1 / 2$ & - & 330 & - \\
\hline $\begin{array}{l}\text { (a) Conductivity units are } \\
\text { (b) Number of samples } \\
\text { (c) Two times the standa }\end{array}$ & $\begin{array}{l}\text { detectable } \\
\text { arror of the }\end{array}$ & $\begin{array}{l}\text { centr } \\
\text { an for }\end{array}$ & $\begin{array}{l}\text { are } p \mathrm{Ci} / \mathrm{L} \text {. } \\
\text { oer of samp } \\
\text { ameters. }\end{array}$ & alyzed. \\
\hline
\end{tabular}




\subsubsection{Upset Conditions}

The nature of upset condltions potentially affecting the environment around or effluent sampling systems in the 331 Complex facilities since 1991 are shown in Table 3.5. This table summarizes the type of events categorized as off-normal or unusual occurrences. The types of events shown in the table could be expected to occur during future operations and are considered in effluent monitoring planning.

Table 3.5. Off-Normal and Unusual Occurrences in the 331 Complex

\begin{tabular}{|l|c|}
\hline \multicolumn{1}{|c|}{ Type of Event } & $\begin{array}{c}\text { Number of } \\
\text { Occurrences }\end{array}$ \\
\hline Radioactive contamination found outside radiation areas or on personnel & 20 \\
\hline Spills or releases of hazardous chemicals (mercury, refrigerant, acetonitrile) & 8 \\
\hline Procedural Violations (failure to follow safety or radiation procedures) & 9 \\
\hline Power Outages, Loss of Ventilation, Loss of exhaust sampling system & 3 \\
\hline $\begin{array}{l}\text { Compromise or degradation of other building systems (e.g. electrical, water, } \\
\text { steam, alarms) }\end{array}$ & 8 \\
\hline Waste Management Concerns (violation, documentation issue) & 2 \\
\hline Theft & 2 \\
\hline
\end{tabular}

The greatest number of occurrences listed were from radioactive contamination found outside designated areas or on personnel. Some of this contamination was discovered during facility modifications and was present from past operations. When known, facility holdup is included in the annual inventory-based assessment or in applicable NOCs so that it is considered in determining facility monitoring requirements. However, the 331 Complex facilities do not currently have any significant facility holdup.

Spills or releases of hazardous chemicals have also occurred in and outside of the 331 Facilities. Specia sampling may be performed in these events to aid in quantifying or characterizing the release or to determine whether there are any continued effects.

A number of procedural violations have occurred, primarily in following safety or radiation-control procedures. These types of events illustrate the need for continued vigilance with respect to effluentmanagement procedures. PNNL's Effluent Management Group has a quality assurance plan (see Section 5.0) that describes training, procedures, quality improvement, and assessments to minimize the potential for unwelcome consequences from procedural violations and to evaluate effects.

Disruptions to the facility primary power, exhaust flow, or air emission sampling systems may interrupt air-emission sampling periods. Because the 331 Building is required to be continuously sampled, interruptions in sampling are minimized by maintaining critical backup components and providing frequent inspections of the sampling system.

Sampling for air chemical emissions or liquid effluents is discretionary, and loss of power or sampling equipment malfunctions are not considered critical. The sampling period can be adjusted or a discrepancy report completed to identify and correct for the effect on the air-chemical or liquid-effluent measurements taken. Section 3.8 discusses alternative sampling methods.

\subsection{Sampling System Description}

Of the 331 Complex emission points, airborne radionuclide emission sampling is performed at the 331 main facility stack (EP-331-01-V) only. The $331 \mathrm{G}$ and $331 \mathrm{H}$ facilities only have sealed sources which do not cause radioactive airborne emissions under normal operating conditions. Thus, the following discussion will focus on the sampling systern at the 331 Facility main stack.

The building main stack, located on the roof of the 331 Facility, discharges ventilation exhaust from 331 laboratories at an exhaust rate of about $61,000 \mathrm{~cm}$. Because the stack flow is primarily building ventilation air, stack-gas specific gravity, humidity, and temperature are typical of the ventilation exhaust from an occupied building. 
To support development of a stack-emission measurement program for the 331 Facility, staff must know the types and quantities of radionuclides potentially present in the ventilation exhaust. An index of emission potential is used by PNNL so that the relative significance of different radionuclides and different emission points can be compared. The index, expressed in terms of a projected potential dose equivalent to a maximum offsite receptor, is based on emission-assessment methods in EPA (1971). It is assumed that no engineered emission controls (e.g., HEPA filters) are provided in the ventilation system and that without such controls, the potential for radionuclide emissions is related to the quantity and physical form of radioactive material in the facility. This assessment method is described in Ballinger et al. (2001).

Radionuclides of primary importance in the 331 Facility from an emission-sampling standpoint are determined on an annual basis, using the above methods. Radionuclides potentially contributing $\geq 10 \%$ of the PTE are specifically analyzed from composited filters every 6 months. Radionuclide inventory varies from year to year. Therefore, the nuclides of interest, those contributing $\geq 10 \%$ of the PTE, are updated annually to account for these variations.

An isokinetic sampling system (ESP-331-01-D) that is compliant with NESHAP requirements in $40 \mathrm{CFR}$ 61 (EPA, 1990) is used to sample continuously for particulate radionuclide emissions. A schematic diagram is provided in Figure 3.1. Detailed descriptions are provided below. The radionuclide sampling system was installed on the main building stack in 1994. The system, which began operating in 1995 , complies with the sampler design criteria in Section 3.2.2.

The airborne radionuclide sampling system incorporates a six-nozzle, isokinetic sampling probe assembly (Figure 3.2) positioned approximately 62 ft above ground in the main stack (Figure 3.3). The probes are eight equivalent diameters downstream of the flex connection at the stack entrance and slightly over two equivalent diameters upstream of the bend leading to the stack exit. Probe nozzles are located at the centers of equal annular areas according to requirements in ANSI N13.1(1969).

Near-isokinetic sampling conditions are maintained by adjusting the flow rate through the collection system so that the average airflow velocity through the sampler inlet nozzles corresponds to the average stack velocity measured at the nozzle locations. Stack emission samples are withdrawn from the stack and through the system by means of the building vacuum air sampling system. Withdrawal rates are controlled by valves located downstream of the sampling system. Flows are measured by a rotameter upstream of the control valves. Stack velocities are measured on a quarterly frequency using Method 2 in 40 CFR 61 (EPA, 1990).

The sample transport line extends from the probe assembly to just outside the stack on the roof where the sample cabinet is located. The transport lines are of stainless steel tubing and are heat traced, thermally insulated, and electrically grounded.

Transport efficiency of the collection systems has been calculated. The transport efficiency of the sampling system is greater than $95 \%$ for an assumed 1 -micron activity median aerodynamic diameters (AMAD) aerosol at nominal sampler and stack flow rates ${ }^{(a)}$.

Airborne particles are collected on a 47-mm-diameter membrane filter (Gellman Versapor 3000TN). The $V-3000 T N$ has an estimated retention efficiency for 0.3 -micron particles of greater than $91 \%$ at face velocities of $180 \mathrm{fpm}$.

(a) Loss calculations were performed using DEPO Version 4.0 (Riehl et al. 1996). A 1-mleron AMAD polydisperse aerosol was assumed for the calculations based on the assumption that building operations and controls (HEPA filters) are "normal." 


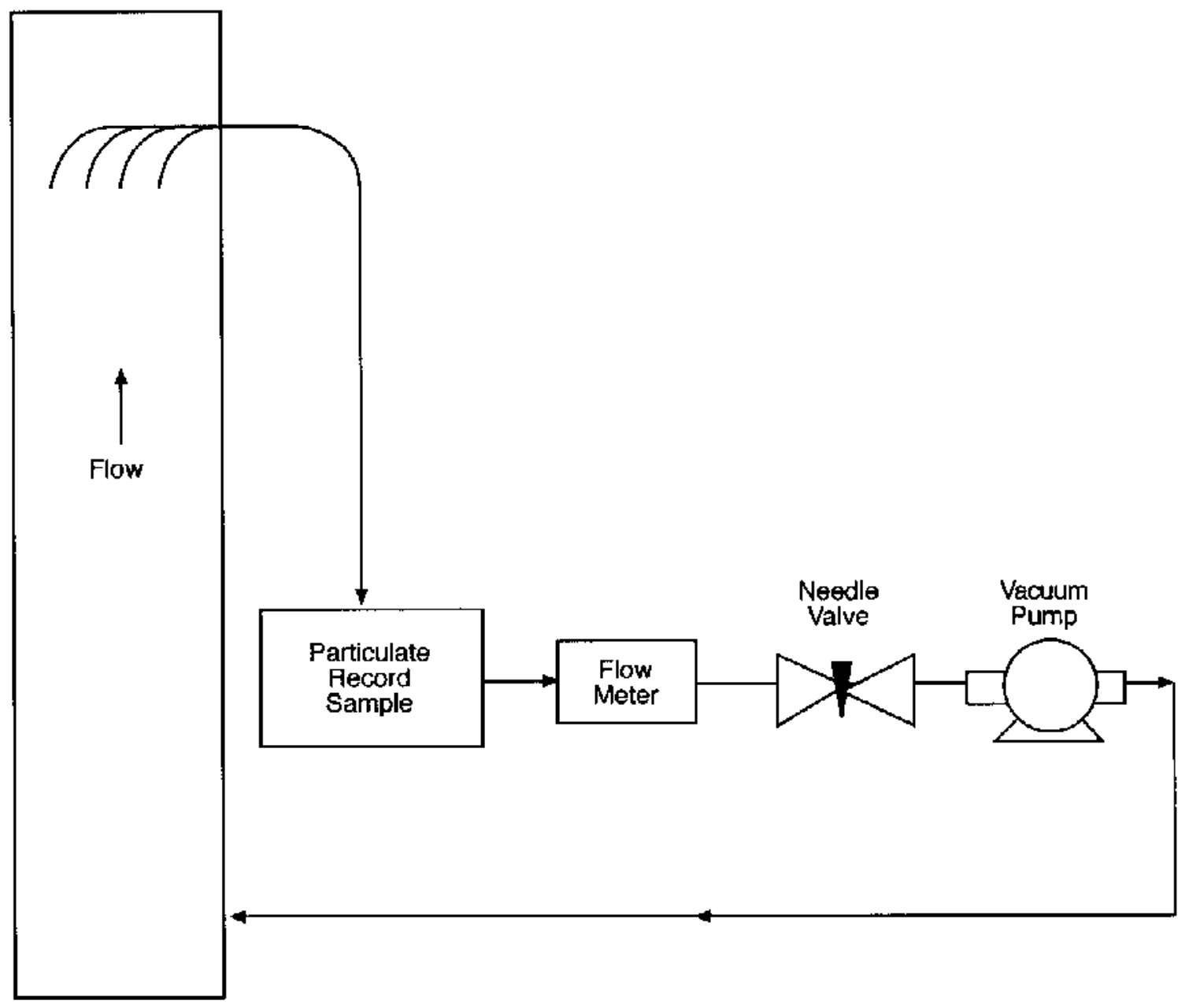

980200087.15

Figure 3.1. Schematic of 331 Main Stack Sampling System 

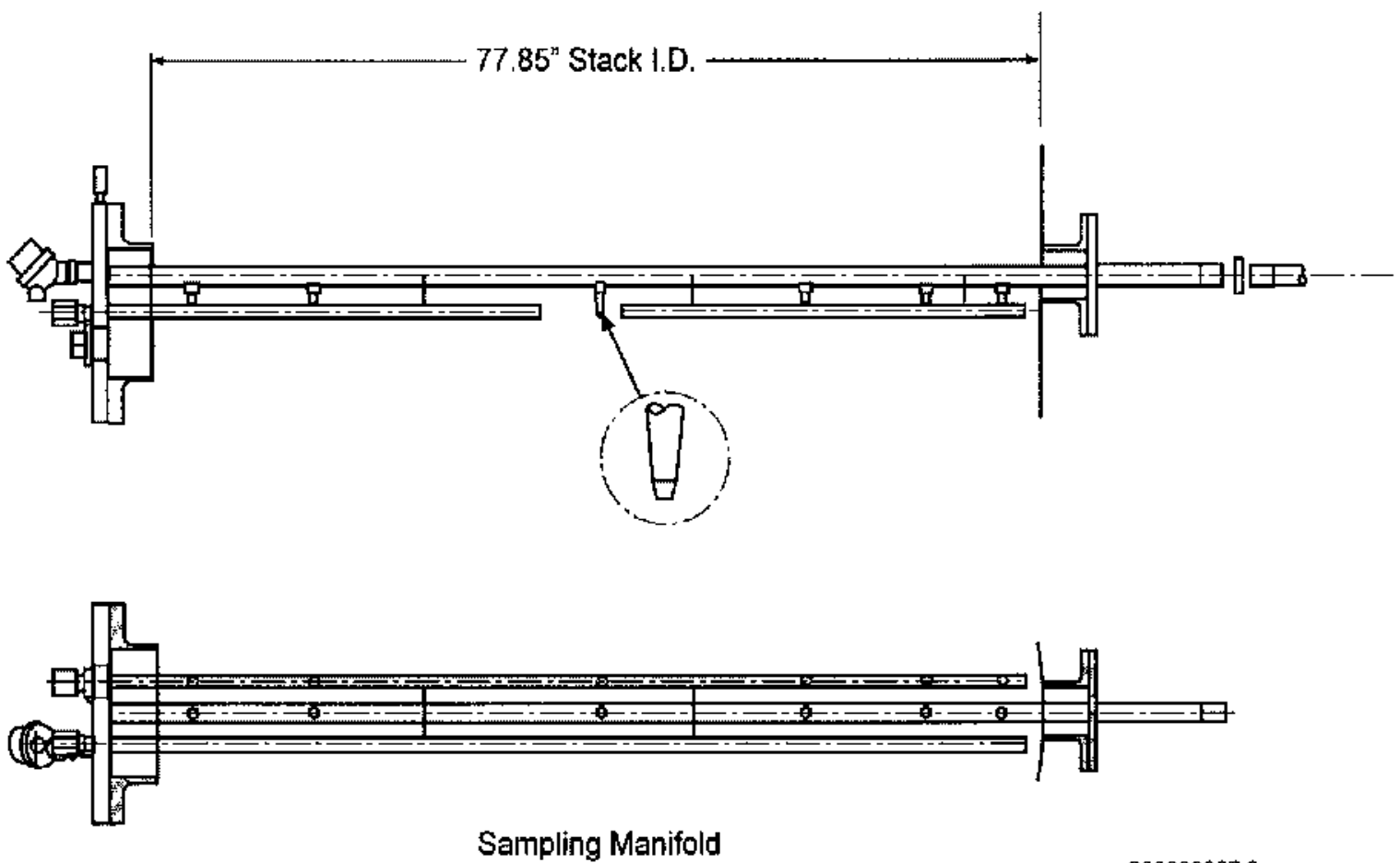

FIgure 3.2. Sampling Probe for 331 Main Stack 


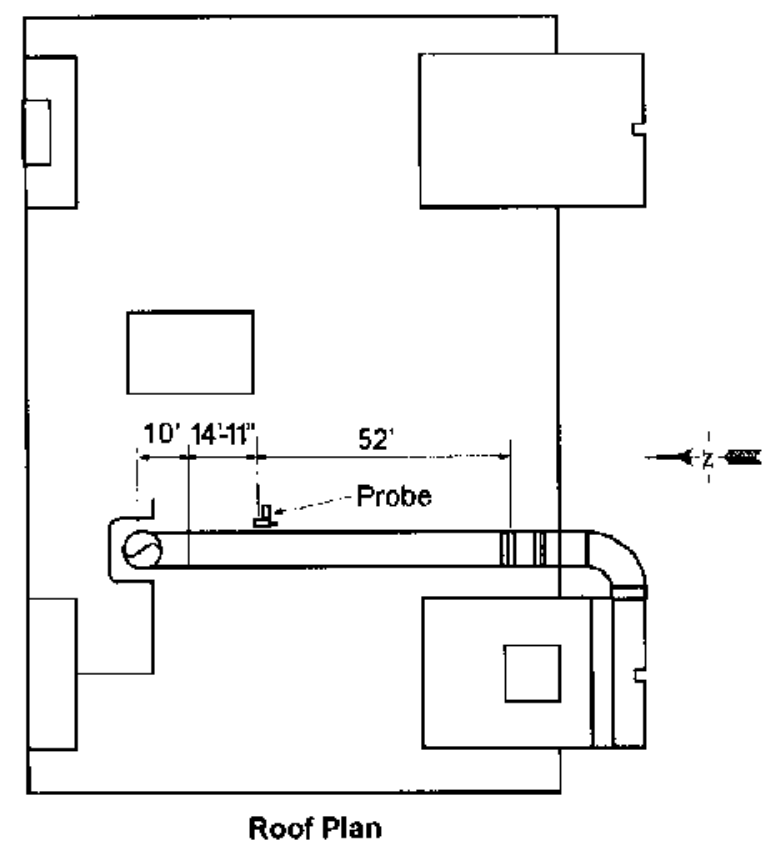

EP-331-01-V Elev 441'-9"

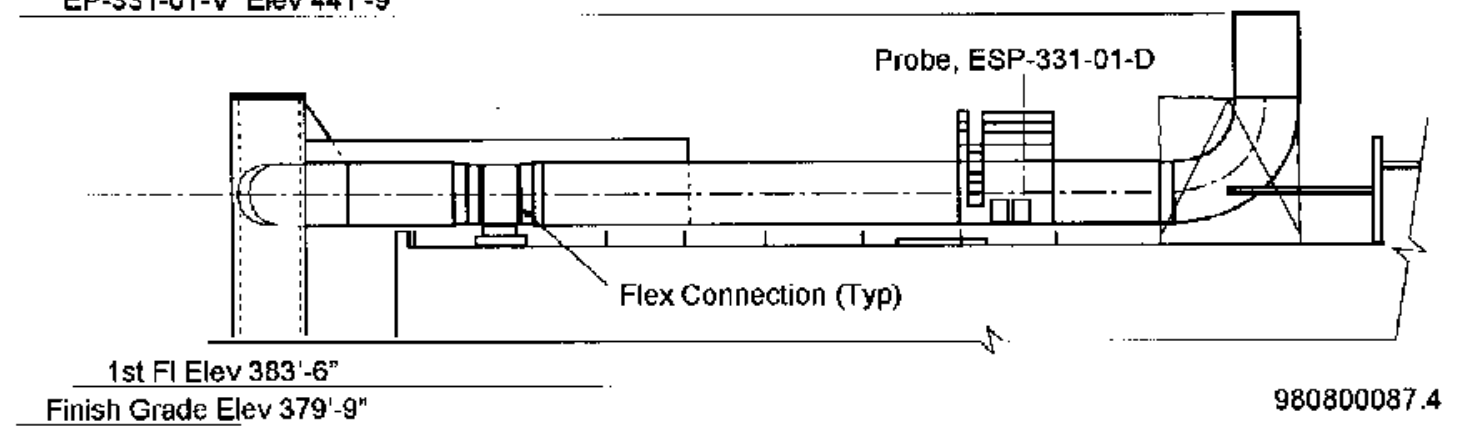

Figure 3.3. 331 Main Stack Sampling System Configuration

The sample collection filter is normally replaced every 2 weeks, but may be replaced more frequently depending on filter loading. The sample filter is stored for a minimum of 5 days after being removed from the sampler to permit decay of radon and thoron daughter radionuclides. The filter is then analyzed for gross-alpha and gross-beta radioactivity.

Each sample is screened individually for gross-alpha and gross-beta activity. Then the samples are collected over a 6-month period (semi-annual), combined, and analyzed for specific radionuclides as determined by the annual inventory assessment. The Chemical Measurement Center (CMC) staff in the Radiochemical Processing Laboratory analyze samples using methods described in Chapter 4.0. Sample analysis results are evaluated as described in Section 3.6.

\subsection{Sampling System Performance}

This section describes the performance capability of the stack sampling system in terms of the offsite dose potentially resulting from a release. The determination of minimum sampler capability is based on a series of assumptions of worst-case-exposure scenarios, resulting in calculations of upper bound doses. Thus, the methods used here to evaluate system capability are not appropriate for assessing actual releases. 


\subsubsection{Stack Radionuclide Sampling System Performance}

Performance criteria for sampling are provided in Section 3.2. Two of the criteria relate to measurement sensitivity, and the third relates to measurement bias. The criterion for bias is based on conformance of the system to design and operational guidance in ANSI N13.1(1969) and DOE/EH-0173T (DOE, 1991). System-description information in Section 3.4 is consistent with the design and operational guidance; thus, the bias criterion is met.

Sensitivity criteria (Section 3.2) for sampling are stated in terms of detectable offsite dose. According to the criteria, compliance sampling shall include measurement of radionuclides that could contribute greater than $10 \%$ of the PTE for the release point. Per performance criteria in Section 3.2.1, radionuclides should be detectable at emission levels resulting in an annual, committed effective dose equivalent of $0.01 \mathrm{mrem} / \mathrm{yr}$. For example, for the 331 Facility, radionuclides required to be measured at the compliance stack (EP-331-01-V) typically include ${ }^{241} \mathrm{Am},{ }^{239} \mathrm{Pu}$, and ${ }^{240} \mathrm{Pu}$. However, a broader range of isotopes are analyzed for all PNNL major emission points because of the variation in activities and inventory throughout the year. Total alpha activity and total beta activity are also measured at all stacks to screen for the presence of particulate radionuclides.

Annual release quantities associated with an effective dose equivalent of $0.01 \mathrm{mrem} / \mathrm{yr}$ were calculated from dose factors obtained using the EPA compliance code CAP-88 (Ballinger et al. 2001). These values are shown in Table 3.6.

The sensitivity of particulate radionuclide sampling is proportional to the collection efficiency of the sampler, the fraction of the emission quantity collected by the sampler (i.e. sampler efficiency), and the level at which the radionuclide can be detected in the collected sample. Under isokinetic sampling conditions, the 331 Facility particulate sampler will intercept approximately $1 / 18,000$ of the activity emitted via the stack (i.e., ratio of sampling rate to stack flow rate). Loss of particulates in the sampling system due to deposition, plateout, and filtering efficiency are estimated to be less than $5 \%$ for a 1-micron AMAD particulate aerosol. ${ }^{\text {(a) }}$ Using the contractual minimum detection level specified in the analytical laboratory statement of work, the annual minimum detectable release for specific radionuclides are as shown in Table 3.6. The detectable annual release is less than that needed to detect an emission resulting in $0.01 \mathrm{mrem} / \mathrm{yr}$.

Table 3.6. Detection of Significant Radionuclides in 331 Stack Emissions

\begin{tabular}{|c|c|c|c|}
\hline Radionuclide & $\begin{array}{l}\text { Analytical Limit } \\
\text { (pCi/sample) }{ }^{(a)}\end{array}$ & $\begin{array}{c}\text { Detectable Annual } \\
\text { Release (Ci) }\end{array}$ & $\begin{array}{l}\text { Emission Resulting } \\
\text { in } 0.01 \text { mrem/yr (Ci) }\end{array}$ \\
\hline Beta Activity & $38^{(1)}$ & $2.4 \mathrm{E}-5$ & $2.4 \mathrm{E}-4$ (as $\left.{ }^{137} \mathrm{Cs}\right)$ \\
\hline Alpha Activity & $1.0^{(0)}$ & $6.4 E-7$ & $4.2 \mathrm{E}-6\left(\mathrm{as}^{241} \mathrm{Am}\right)$ \\
\hline${ }^{230} \mathrm{Pu}$ & $1^{(c)}$ & $4.2 \mathrm{E}-8$ & $7.2 \mathrm{E}-6$ \\
\hline${ }^{2397240} \mathrm{Pu}$ & $1^{(\mathrm{c})}$ & $4.2 \mathrm{E}-8$ & $6.7 \mathrm{E}-6$ \\
\hline \multicolumn{4}{|c|}{$\begin{array}{l}\text { (a) From analytical lab statement of work. } \\
\text { (b) Includes correction for } 15 \% \text { reduction of the alpha and beta emissions originating from the sample } \\
\text { that are absorbed by the sample media and surface dirt on the filter (Higby 1984). } \\
\text { (c) Value for a 6-month composited group. } \\
\text { (d) Based on dose-per-release factors calculated for onsite worker in } 2001 \text { using CAP-88. }\end{array}$} \\
\hline
\end{tabular}

\subsubsection{Liquid Effluent Sampling and Monitoring}

The aquaculture system serves the 331 Aquatics Research Laboratory that draws on both river and well water sources for supplying water for fish-rearing activities. Wastewater from these operations is discharged to an outfall structure located East of the 331 Building outside the fence-line of the 300 Area. This discharge was previously known as Outfall 013A of the Hanford Site NPDES permit (WA-000374-3), but was exempted when the permit was revised in 1999.

(a) Calculated using DEPO 4.0 (Riehl et al. 1996) assuming a particulate aerosol with an AMAD of 1.0 microns. 
PNNL continues to sample the aquaculture system through an agreement with DOE as a best management practice. Sampling is performed at a concrete monitoring station and flume enclosure located approximately 11 feet upstream of the outfall headwall ${ }^{(2)}$. The monitoring station consists of a 10 -inch flume insert, a flow meter, and a refrigerated sampler. This sampler may be operated in composite, time-proportional, and flow-proportional sample-collection mode. Figure 2.11 is a diagram of the aquaculture system.

Several 331 Complex facilities $(331,331 \mathrm{D}, 331 \mathrm{G}, 331 \mathrm{H})$ have laboratories that are serviced by the PS. A liquid-effluent sampling and monitoring system is installed in the PS at a location downstream of these facilities. The system has been used and continues to be used to characterize facility effluents, when needed, and to investigate potential discharges of concern. The primary criteria for this sampling system includes:

- Sampling capability is sufficient to obtain grab and composite samples for effluent characterization data.

- Characterization sampling must verify that a valid sample is obtained and that the sample can be analyzed for almost any chemical or parameter.

- Sampling and monitoring equipment is sufficient to enable periodic verification of effluent characteristics as neөded.

- Sampling and monitoring equipment provides the capability to investigate potential discharges of concern.

The PS liquid-effluent sampling system is located outside of the 331 Building and is currently being repositioned after facility piping modifications. The system will have the capability to measure $\mathrm{pH}$ and flow as well as taking grab or flow-composite samples. The refrigerated sampler controls temperature of samples taken to meet preservation requirements. Figure 3.4 is a schematic of the system. PNNL's Effluent Management Group has sampling procedures in place and a contract with an analytical laboratory to meet sampling requirements.

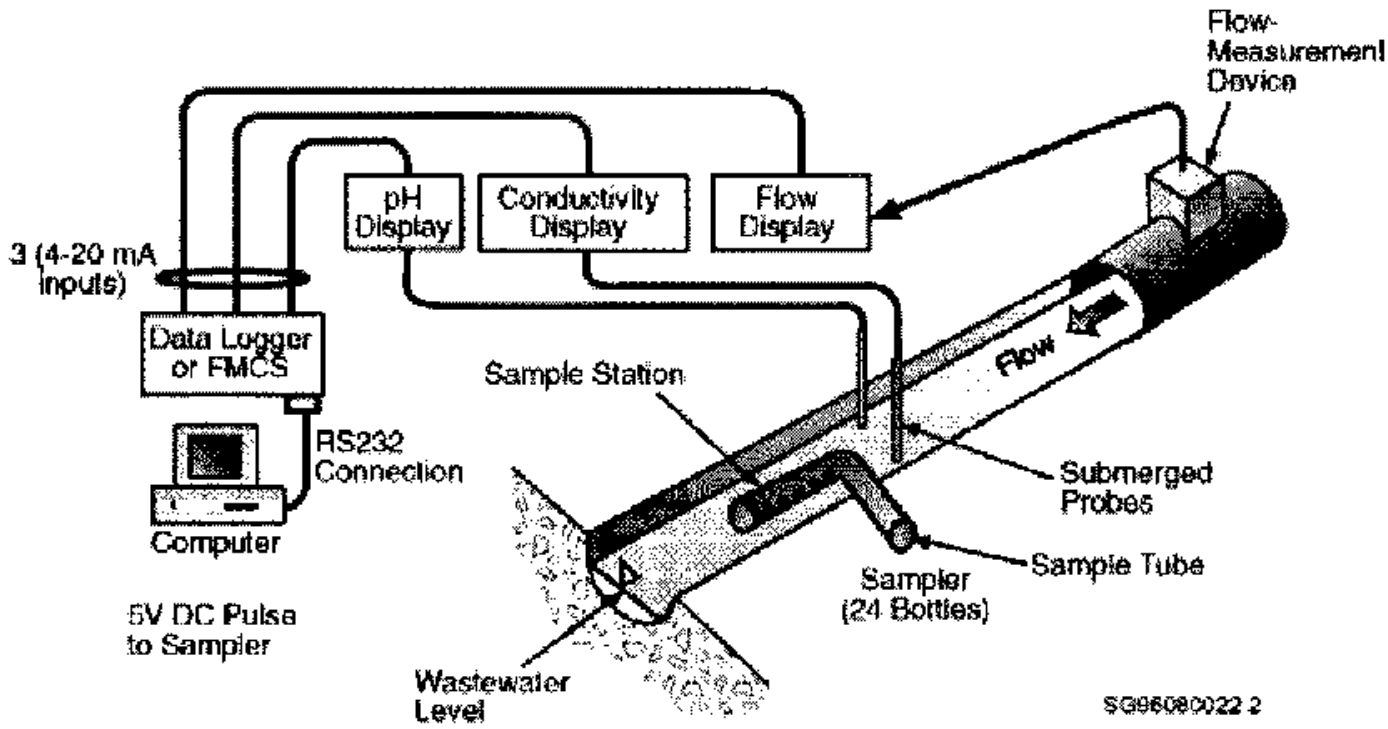

Figure 3.4. Schernatic of 331 Complex PS Sampling and Monitoring System

(a) The area between the headwall and the river consists of riprap overgrown with plants and vegetation, sloping down-gradient for approximately 58 meters before final discharge to the Columbia River. 


\subsection{Handling of Sampling and Monitoring Data}

Routine compliance measurements are taken from the 331 main stack for radiological air emissions. In addition, periodic sampling or monitoring data on air chemical emissions from the 331 Building or on 331 Complex PS or aquaculture wastewater discharges may be collected to verify, characterize, or investigate effluents. This sampling is performed by PNNL's Effluent Management Group. Sampling data are handled according to the following general requirements:

- Chain of Custody (COC) forms are generated for each sample to track the sample from collection through disposal. COCs contain the place, date, and time of sampling; who performed the sampling and measurements; the signature, name, date, and time of transfers; and any applicable special instructions on storage and preservation or reference to a statement of work (SOW) for specific instructions. For field measurements where the measurement is taken immediately (within 15 minutes) and the sample is not transferred, the COC information can be documented in a log book.

- Data are validated to detect potential quality problems in analytical data. Data are reviewed for 1) results that indicate detectable sample activity or chemical concentration, 2) results above any pre-defined action level, and 3) results that are unexpected compared to historical measurements.

- Discrepancies, anomalies, unusual data, or data above action levels are investigated and the resolutions documented using a discrepancy report.

- Manipulation of measurement data into a format that will be reported to DOE or regulatory agencies or that will be used as a basis for regulatory decisions is documented for traceability. Technical reviews are performed on calculations involving sampling data to verify accuracy.

- Sampling data records are maintained according to regulatory requirements that are specified in the Effluent Management Project Records Inventory and Disposition Schedule (RIDS).

\subsubsection{Radiological Air-Emission Data}

Results obtained from the radiological air-emission sampling program are used to evaluate existing facility emission levels and to calculate annual emission quantities for compliance determination and reporting purposes.

Particulate samples are collected as described in Section 3.2. Analysis of samples by a laboratory is described in Chapter 4. Data are evaluated using documented and approved procedures. Data evaluation procedures are based on guidance in DOE/EH-0173T (DOE, 1991), Environmental Regulatory Guide for Radiological Effiuent Monitoring and Environmental Surveillance and EPA 520/1-80-012 (EPA, 1980), Upgrading Environmental Radiation Data.

Airborne-emission sampling data are reviewed for anomalies and trends. Provisional release estimates are updated throughout the sampling year (calendar year) as data are received. At the completion of the calendar year, data are reviewed. The provisional release estimate is refined, as necessary, to account for anomalies or missing data as well as a significantly skewed data set. Anomalous data are investigated, and conclusions of the investigation are documented.

Final release quantities include corrections for isokinetic sampling efficiency, sample transport losses, sample self-absorption, decay, counting efficiency, background, and collection media efficiency.

\subsection{Calibration and Maintenance of Equipment}

Sampling and monitoring equipment, including rotameters, are maintained and calibrated according to schedules determined when the equipment is installed or purchased. Stack flow rates are measured using a standard-type pitot tube that is recognized by EPA as a primary calibration standard. The aquaculture outfall flow meter is calibrated as recommended by the manufacturer. Equipment used to measure $\mathrm{pH}$ is user-calibrated before each use. Radiation-monitoring equipment is calibrated annually by 
the Radiation Instrumentation Services of PNNL. This group has responsibility for calibrating all portable radiation-protection instrumentation at Hanford.

Continuous, "major", sampling systems are inspected each workday by the PNNL Radiation Protection Section for proper flow-rate setting and system operation. "Minor" sampling systems are inspected weekly during sampling periods.

Preventative maintenance activities for installed facility effluent sampling and monitoring equipment are tracked by PNNL Maintenance Services. Calibrations are primarily provided by PNNL's Instrumentation Services and Technology Group. PNNL's Effluent Management Group supports calibration and maintenance by helping develop calibration and maintenance procedures, obtaining vendor information on recommended calibration and maintenance or on equipment functions, working with Building Managers to identify needed repairs, and performing inspections of sampling systems when necessary to verify proper functioning. The SBMS Subject Areas, Service Request Process, and Calibration provides requirements and guidance pertinent to Calibrations and Maintenance.

\subsection{Alternative Sampling Methods}

Critical sampling and monitoring system components have replacement units available, minimizing down time to a few hours.

Alternative methods exist for assessing impacts of facility emissions. Workplace air-monitoring systems provide evidence of the presence or absence of radionuclides in room air. Contamination surveys routinely performed throughout the facilities for radiological work areas provide additional evidence of contamination spreads. Differential pressure gauges installed across each filter bank provide evidence of filter plugging or breakthrough.

Alternative sampling methods for liquid effluent sampling for the 331 Complex facilities are not needed because sampling is periodic and can be rescheduled if the sampling system malfunctions. However, spare parts and portable samplers are also available when needed.

An extensive environmental surveillance program is operated for the Hanford Site by PNNL. This program is described in detail in the Hanford Site Environmental Monitoring Plan (DOE 2000). The program performs ambient air sampling around the 300-Area perimeter as well as along the Hanford Site boundary and in adjacent communities. In addition to ambient air sampling, the Environmental Surveillance Program samples groundwater, river water, drinking water, foodstuffs, soil, native vegetation, and aquatic and terrestrial animals. Annual reports issued by the Hanford Environmental Surveillance Program docurnent the results of these samples. 
This page intentionally left blank. 


\subsection{Laboratory Analyses}

This section provides information on the analytical laboratories and procedures used to analyze samples collected in support of the PNNL effluent monitoring program. As stated in previous sections, these samples may contain radioactivity associated with emissions from the 331 Facility main stack, or chemicals or chemical parameters associated with the $\mathbf{3 3 1}$ aquaculture outfall or PS. Air chemical emissions, when sampled, are analyzed following EPA Compendium Method TO-15 in the PNNL Field Hydrology and Chemistry Group analytical laboratory.

Section 3.5 describes the types of samples collected by the 331 Building main stack sampling system. These samples are for particulate radionuclides on filter paper. Also, liquid effluent samples are collected from the 331 aquaculture system as a best management practice and periodically from the $331 \mathrm{PS}$. The laboratories and procedures used to perform sample analyses are described in Section 4.1. Section 4.2 provides a description of procedures employed by PNNL and its supporting analytical laboratories.

\subsection{Analytical Procedures}

Analytical procedures for alpha and beta particulate radioactivity, isotopic analysis, and chemical contaminants in liquid samples are provided in this section. The principal radionuclides in 331 Building emissions are described in Section 3.5. These radionuclides are detectable using procedures described in this section. Analyses are performed by the CMC of the PNNL Radiochemical Processing Group located in the Radiochemical Processing Laboratory. All analytical work associated with radionuclide sampling is performed according to required methods per PNNL contract and SOW with the analytical laboratory. The SOW is prepared to meet the quality assurance requirements from 40 CFR 61 (EPA 1990).

\subsubsection{Determination of Alpha and Beta Activity on Particulate Air Filters}

Particulate air filter samples from the 331 Building main stack are collected on a frequency as described in Section 3.4. The samples are initially delivered to a laboratory operated by PNNL's Radiation Protection Section. The samples are held at the laboratory to allow for adequate decay of radon daughter radionuclides.

Following the hold time for radon daughter decay, each particulate filter is delivered to the CMC where analytical services are performed according to documented requirements in a SOW.

Samples are received, logged in, classified, and analyzed according to procedures documented as Standard Operating Procedures (SOPs).

The CMC particulate alpha and beta analysis method are documented in CMC SOPs. Samples are counted on an alpha and beta proportional counter. The counters are operated with a full open energy window and are calibrated using ${ }^{239} \mathrm{Pu}$ and ${ }^{90} \mathrm{Sr}$ sources corrected for self-absorption. As specified in the SOW, required detection levels are 1-pCi/sample alpha and 38-pCi/sample beta activity on a single (2-week sample) filter for Type I and Type II errors of 0.05. Section 3.5.1 addresses the performance capability of the particulate emission sampling program in terms of detectable offsite dose.

\subsubsection{Isotopic Analysis}

The record particulate filters analyzed by CMC for alpha and beta, as discussed in Section 4.1.1, are further analyzed for radionuclides contributing $10 \%$ or greater of the potential-to-emit. These analyses are performed by $\mathrm{CMC}$ on particulate samples composited on a semi-annual basis.

The CMC composite preparation and analysis methods used for the above isotopes are listed in Table 4.1. As specified in the SoW, required detection levels are also listed in Table 4.1. 
Table 4.1. Isotopic Separation and Analysis Methods

\begin{tabular}{|l|c|}
\hline \multicolumn{1}{|c|}{ Method } & $\begin{array}{c}\text { MDA } \\
\text { (pCi/sample) }\end{array}$ \\
\hline Air Filter Preparation and Compositing & $-\mathrm{NA}-$ \\
\hline Gamma Analysis Sample Preparation, All Matrices & $38^{(\mathrm{al}}$ \\
\hline Electrodeposition Procedure for the Actinides & $-\mathrm{NA}-$ \\
\hline Strontium Determination for 6-month Filter Composites & 38 \\
\hline $\begin{array}{l}\text { Isotopic Plutonium Determination for 6-month Filter } \\
\text { Composites }\end{array}$ & 1 \\
\hline $\begin{array}{l}\text { Isotopic Americium/Curium Determination for 6-month } \\
\text { Filter Composites }\end{array}$ & 0.7 \\
\hline (a) - Based on ${ }^{137} \mathrm{Cs}$, will depend on isotope & \\
\hline
\end{tabular}

Before digesting the particulate filters for isotopic analysis, the filters are grouped on a semi-annual basis in preparation for gamma scan analysis. The semi-annual groups of samples are transferred to a standard geometry container for counting on the gamma detectors. Intrinsic Germanium (high-purity germanium) detectors are used to detect isotopes with gamma ray energies between 60 and 2,000 eV.

Following the gamma scan, the semi-annual groups are digested and the elements of interest are separated from other elements and the sample matrix by chemistry. The ${ }^{90} \mathrm{Sr}$ content is determined by the chemical separation and counting of a daughter element, ${ }^{90} Y$. The strontium is separated from other elements chemically, then ${ }^{90} \mathrm{Y}$ is permitted to grow into equilibrium with the ${ }^{90} \mathrm{Sr}$. The ${ }^{50} \mathrm{Y}$ is then separated and processed to determine the chemical recovery and counted on a low background beta proportional counter. The quantity of ${ }^{90} \mathrm{Sr}$ is then determined based on the quantity of the daughter ${ }^{90} \mathrm{Y}$ produced.

Plutonium is separated from other elements and the sample matrix by adsorption on an anion exchange column. The plutonium is then processed chemically and electroplated or coprecipitated on rare earth fluorides. Isotopic concentrations of the deposited material is determined by alpha spectrometry. Following the removal of the plutonium, the sample matrix is further processed chemically and the americium and curium removed by passing the sample through a cation exchange column. The americium and curium are eluted from the column and either electroplated or coprecipitated. As with the plutonium, isotopic concentrations of the deposited material is determined by alpha spectrometry.

\subsubsection{Liquid Effluent Samples}

Liquid effluent samples are collected from the 331 aquaculture outfall on a periodic basis as a best management practice. Aquaculture liquid waste samples are shipped to an analytical laboratory contracted by PNNL. Analytical work is performed according to required methods per the PNNL contract and SOW with the lab.

Non-routine liquid effluent samples may also be collected from the 331 PS. Desired analyses for nonroutine samples may be performed in the field, at the PNNL Effluent Monitoring laboratory, or shipped to another PNNL. analytical laboratory or a commercial analytical laboratory offsite. Analytical procedures may vary depending on the sampling concern. Analyses needed to determine compliance or support compliance decisions are performed using methods designated by the appropriate regulatory agency.

\subsection{Procedures}

PNNL's Effluent Management Group maintains documented technical and operation procedures for all aspects of environmental monitoring. The SBMS Subject Area Procedures, Permits, and Other Work Instructions contains the requirements for preparation, review, and approval of these procedures.

Effluent management procedures incorporate all elements required by SBMS.

Sampling procedures include identification of applicable staff, identification of possible hazards encountered while collecting samples, emergency contacts, any applicable prerequisites to performing 
the work, and work instructions. The work instructions address areas such as: equipment operation; sample collection media to be used; amount of sample to be collected; and sample preservatives (as needed).

Effluent Management maintains documented chain-of-custody procedures for all samples. Procedures include provisions for transfer of samples between operational staff, to and from regulated storage areas, and to the analytical laboratory. Both PNNL and any offsite analytical services contractor implement chain-of-custody within the Laboratory.

The analytical laboratory maintains documented and approved chain-of-custody procedures for the preliminary analyses of particulate emission samples and for record analysis of particulate air filters. Radiological air emission samples are stored for eighteen months before being discarded. 
This page intentionally left blank. 


\subsection{Quality Assurance Requirements}

\subsection{Quality Assurance Plan}

A number of Quality Assurance (QA) plans were developed to address QA for the different types of effluent-monitoring activities performed by PNNL, including radiological air, chemical air, and liquid effluent sampling and monitoring. These plans were integrated into one Effluent Management QA Plan in 1997. This plan has been updated on an annual basis and addresses QA for all PNNL effluentmanagement activities. The current QA program described by the plan is based on the following general requirements and guidance:

- DOE Order 414.1A, Quality Assurance (DOE 1999)

- 10 CFR 830.120 Quality Assurance (DOE 1994)

- PNNL Quality Homepage, General Quality Assurance Planning

- DOE Order 5400.1, General Environmental Protection Program (DOE 1988)

- U.S. Environmental Protection Agency (EPA) QAMS-005/80, Interim Guidelines and Specifications for Preparing Quality Assurance Project Plans. (EPA 1980)

- American National Standards Institute/American Society for Quality Control (ANSI/ASQC) E4-1994, American National Standard Specifications and Guidelines for Quality Systems for Environmental Data Collection and Environmental Technology Programs (ANSI/ASQC 1994).

- DOE/EH-0173T, Environmental Regulatory Guide for Radiological Effluent Monitoring and Environmental Surveillance (DOE 1991).

In addition, QA requirements specified in permits and regulations, including 40 CFR 61 (EPA 1990) for PNNL. effluent sampling or monitoring activities are incorporated into the QA Plan.

\subsection{Internal and External Plan Review}

DOE 5400.1 (DOE 1988) states that the Environmental Monitoring Plan will be reviewed annually and updated every 3 years. As a support document to the plan, the FEMP will also be updated every 3 years. At a minimum, the FEMP assessment will be performed annually. 
This page intentionally left blank. 


\subsection{Program Implementation Procedures}

The Hanford Site Environmental Monitoring Plan (DOE 2000) documents the effluent-monitoring and environmental surveillance programs for the Hanford Site.

\subsection{Interface with the Near-Facility Environmental Monitoring Program}

The EMP divides the effluent-monitoring coverage into two areas, the FEMPs and the Near-Facility Environmental Monitoring Program. The FEMPs cover the monitoring of effluents with in the facility. PNNL's Effluent Management Project maintains implementation procedures for all PNNL facilitymonitoring activities. These procedures meet the PNNL requirements for technical and operating procedures (SBMS, Procedures, Permits, and Other Work Instructions) and verify that facility effluent sampling and monitoring is conducted compliantly. The Near-Facility Program monitors air, surface water, groundwater, soil, sediment, vegetation, and biota around site facilities to evaluate the adequacy of effluent control at various facilities at the Hanford Site. The program is conducted by Waste Management Federal Services, Inc. Northwest Operations.

\subsection{Interface with the Operational Environmental Surveillance Program}

Environmental surveillance of the 300 Area and the surrounding onsite and offsite areas is performed by the PNNL Hanford Site Surface Environmental Surveillance Project and the PNNL Site-Wide Groundwater Monitoring Project. These projects are notified in the event of actual or apparent new or off-normal discharges to the soil, surface waters, or air so they can assist in assessing their environmental and compliance significance. The data from these programs are also useful to verify the occurrence or nonoccurrence of facility releases. These surveillance projects are described in detail in DOE/AL-91-50 (DOE, 2000). 
This page intentionally left blank. 


\subsection{Reporting}

This section describes the compliance reporting and notification requirements related to facility effluent monitoring activities for the 331 Complex. It also identifies the requirements and provides an overview of the procedural steps for the notification, investigation, and reporting of all environmental off-normal events for PNNL, operations.

\subsection{Routine Effluent Monitoring Reports}

On a periodic basis, effluent monitoring data are gathered by PNNL on specific DOE Richland Operations Office (DOE/RL) facilities for compilation and reporting to DOE and the various regulatory agencies.

The following effluent monitoring reports are submitted to regulatory agencies:

\section{Airborne Effluent}

- An Annual NESHAP Air Emissions Report for the Hanford Site providing the required annual emissions measurements and climatological data is submitted to the U.S. Environmental Protection Agency (EPA) and the WDOH for the Hanford Site radioactive airborne emissions.

- The Annual Radioactive Effluent and Onsite Discharge Data Report is submitted to DOE. Headquarters, the EPA, and WDOH through DOE/RL.

- Semiannual Reports providing updates of compliance-related activities under the Hanford Air Operating Permit (AOP) (WDOE 2001) are submitted to WDOE. These require reporting deviations from monitoring and sampling requirements or emission limits, any required source test and monitoring reports, and the results of any air emission compliant investigations.

- An Annual Compliance Certification to WDOE, WDOH, Benton Clean Air Authority (BCAA), and EPA that certifies continuous or intermittent compliance with sampling and monitoring requirements, and emission limits under the AOP.

- Annual Nonradioactive Inventory and Airborne Emissions Report to WDOE documenting requested emissions data pursuant to WAC 173-400-105.

\section{Liquid Effluent}

- WDOE is provided an annual report on significant discharges of hydrotest, maintenance, or construction wastewater discharged to ground as required by permit ST-4508 (WDOE 1997).

Other

- WDOE is provided with a monthly status report of all reportable spills from the previous month through DOE/RL.

- Annual Hanford Site Notification of Intent (NOI) for planned asbestos removal activities is submitted to BCCA through Fluor Hanford by December $15^{\text {th }}$ each year. [BCAA Regulation 1, 40 CFR 61, Subpart M].

\subsection{Non-Routine Notifications and Reports}

There are a number of reports, including notification reports that are required with respect to effluent monitoring activities.

- A Notice of Construction (NOC) must be provided to WDOH and/or WDOE and/or BCAA depending on emissions type, whenever a new emission unit is to be created, or if there is to be significant modification to an existing emission unit. Applicable NOCs are maintained on a web site by PNNL Effluent Management and are linked to Facility Use Agreements.

- Prompt reporting of abnormal or upset conditions, or deviations from permit or contractual requirements to WDOH and/or WDOE and/or the City of Richland is required by the AOP and the SNS contract. A Notification Follow-up Report may also be requested in addition to the initial notification. 
- A Report of Closure shall be submitted to WDOH whenever an emission unit covered under WAC 246-247 (WAC 1994) ceases emission.

- Notification of Intent to Remove Asbestos Containing Material, or to Demolish must be submitted to BCAA and if required, the U.S. EPA, 10 working days in advance of removal activity, should specific regulatory thresholds be exceeded (BCAA Regulation 1, 40 CFR 61, Subpart M).

\subsection{Event Notification and Reporting}

"Events" or conditions may adversely affect DOE or contractor personnel, the public, property, the environment, or the DOE mission. Staff who discover an event that requires mitigation, must notify the Battelle single-point-contact to begin the response and mitigation process. Managers who are notified of events within their domain participate in the recovery, evaluation, analysis, and corrective action of the event. These two processes, staff notification, and management participation are described in PNNL SBMS Subject Area, Event Reporting. The Subject Area incorporates requirements from DOE 232.1A, "Occurrence Reporting and Processing of Operations Information" (DOE 1997) and associated DOE/RL Directives. 


\subsection{References}

ANSI. 1969. Guide to Sampling Airborne Radioactive Materials in Nuclear Facilities, ANSI N13.1-1969. American National Standards Institute

ANSI. 1980. Specifications and Performance of Onsite Instrumentation for Continuously Monitoring Radioactivity in Effluents, ANS1 N42.18 1980b. American National Standards Institute.

ANSI. 1999. Sampling and Monitoring Releases of Airborne Radioactive Substances From the Stacks and Ducts of Nuclear Facilities, ANSI N13.1-1999. American National Standards Institute

ANSI/ASQC. 1994, American National Standard Specifications and Guidelines for Quality Systems for Environmental Data Collection and Environmental Technology Programs. E4-1994. American National Standards Institute/American Society for Quality Control.

Ballinger, MY, MJ Sula, TL Gervais, KD Shields, and DL Edwards. 2001. Assessment of Unabated Facility Emission Potentials for Evaluating Airborne Radionuclide Monitoring Requirements at Pacific Northwest National Laboratory - 2001, PNL-10855 Rev. 2 AD-902, Pacific Northwest National Laboratory, Richland, Washington.

Diediker, LP, and K Rhoads. 1999. Radionuclide Air Emissions Report for the Hanford Site, Calendar Year 1998. DOE/RL-99-41, U.S. Department of Energy, Richland Washington.

Gerber, M. S. 1992. Past Practices Technical Characterization Study - 300 Area - Hanford Site. WHC-MR-0388, Westinghouse Hanford Company, Richland, Washington.

Higby, D. P. 1984. Effects of Particle Size and Velocity on Burial Depth of Airborne Particles in Glass Fiber Filters. PNL-5278, Pacific Northwest Laboratory, Richland, Washington.

McCarthy, M. J. 1990. Westinghouse Hanford Company Effluent Report for 300, 400, and 1100 Area Operations for Calendar Year 1989. WHC-EP-0267-1, Westinghouse Hanford Company, Richland, Washington.

PNNL Quality Homepage, General Quality Assurance Planning)

(http:/quality.pnl.gov/guidance/genqaplan/qaplan.htm).

Riehl, J., V. R. Dileep, N. K. Anand, A. R. McFarland. 1996. Depostion 4.0 An Illustrated Users Guide. Texas A\&M University, College Station, Texas.

Rokkan, DJ, LP Diediker, DL Dykeman, NA Homan, K Rhoads, and LH Staven. 2002. Radionuclide Air Emissions Report for the Hanford Site, Calendar Year 2001. DOE/RL-2001-32, U.S. Department of Energy, Richland Washington.

Rokkan, DJ, and K Rhoads. 2000. Radionuclide Air Emissions Report for the Hanford Site, Calendar Year 1999. DOE/RL-2000-37, U.S. Department of Energy, Richland Washington.

Rokkan, DJ, and K Rhoads. 2001. Radionuclide Air Emissions Report for the Hanford Site, Calendar Year 2000. DOE/RL-2001-32, U.S. Department of Energy, Richland Washington.

SBMS, Airborne Emissions. 2002. Airborne Emissions. Standards-Based Management System Subject Area (http://sbms.pnl.gov/standard/Og/Og0oto10.htm ), Pacific Northwest National Laboratory, Richland, Washington.

SBMS, Calibration. 2002. Calibration. Standards-Based Management System Subject Area (http:/sbms.pnl.gov/standard/79/7900t010.htm), Pacific Northwest National Laboratory, Richland, Washington. 
SBMS, Creating or Modifying Engineering Calculations, Drawings, and Specifications. 1997. Creating or Modifying Engineering Calculations, Drawings, and Specifications. Standards-Based Management System Subject Area (http://sbms.pnl.gov/standard/91/9100t010.htm ), Pacific Northwest National Laboratory, Richland, Washington.

SBMS, Event Reporting. 2001. Event Reporting. Standards-Based Management System Subject Area (http://sbms.pnl.gov/standard/27/2700t010.htm ). Pacific Northwest National Laboratory, Richland, Washington.

SBMS, Managing Liquid Effluents. 1998. Managing Liquid Effluents. Standards-Based Management System Subject Area (http://sbms.pnl.gov/standard/oq/0q00t010.htm ), Pacific Northwest National Laboratory, Richland, Washington.

SBMS, Managing Waste. 2002 . Managing Nonradioactive Chemical Waste. Standards-Based Management System Subject Area (http://sbms.pnl.gov/standard/Of/Of00t010.htm), Pacific Northwest National Laboratory, Richland, Washington.

SBMS, Procedures, Permits, and Other Work Instructions. 2002. Procedures, Permits, and Other Work Instructions. Standards-Based Management System Subject Area

http://sbms.pnl.gov/standard/74/7400t010.htm, Pacific Northwest National Laboratory, Richland, Washington.

SBMS, Service Request Process. 2000. Service Request Process. Standards-Based Management System Subject Area (http://sbms.pnl.gov/standard/97/9700t010.htm), Pacific Northwest National Laboratory, Richland, Washington.

SBMS, Working with Chemicals. 2002. Working With Chemicals. Standards-Based Management System Subject Area (http://sbms.pnl.gov/standard/03/0300t010.htm) ), Pacific Northwest National Laboratory, Richland, Washington.

Thompson, C.J., M.Y. Ballinger, E.G. Damberg, and R.G. Riley. 1997. Characterization and Monitoring of 300 Area Facility Liquid Waste Streams During 1994 and 1995. Pacific Northwest National Laboratory, Richland, Washington.

U.S. Department of Energy (DOE). 1987. General Design Criteria, DOE 6430.1A, U.S. Department of Energy Order. U.S. Department of Energy. Washington D.C.

U.S. Department of Energy (DOE). 1988. General Environmental Protection Program, DOE 5400.1, U.S. Department of Energy Order. U.S. Department of Energy. Washington D.C.

U.S. Department of Energy (DOE). 1990. Radiation Protection of the Public and the Environment, DOE 5400.5, U.S. Department of Energy Order. U.S. Department of Energy. Washington D.C.

U.S. Department of Energy (DOE). 1991. Environmental Regulatory Guide for Radiological Effluent Monitoring and Environmental Surveillance, DOE/EH-0173T. U.S. Department of Energy. Washington D.C.

U.S. Department of Energy (DOE). 1994. Quality Assurance. 10 CFR 830.120. Department of Energy, U.S. Code of Federal Regulations.

U.S. Department of Energy (DOE). 1997. Occurrence Reporting and Processing of Operations Information, DOE 232.1A. U.S. Department of Energy Order. U.S. Department of Energy. Washington, D.C.

U.S. Department of Energy (DOE). 1999. Quality Assurance. DOE 414.1A. U.S. Department of Energy Order. U.S. Department of Energy. Washington D.C. 
U.S. Department of Energy (DOE). 2000. Environmental Monitoring Plan, United States Department of Energy, Richland Operations Office. DOE/RL-91-50, Rev. 3, U. S. Department of Energy, Richland Washington.

U.S. Environmental Protection Agency (EPA). 1971. Regulations on Standards of Performance for New Stationary Sources, Appendix A: Reference Methods. 40 CFR 60. Environmental Protection Agency, U.S. Code of Federal Regulations.

U.S. Environmental Protection Agency (EPA). 1980. Upgrading Environmental Radiation Data. EPA 520/1-80-012. U.S. Environmental Protection Agency. Washington D.C.

U.S. Environmental Protection Agency (EPA). 1980. Interim Guidelines and Specifications for Preparing Quality Assurance Project Plans. QAMS-005/80. U.S. Environmental Protection Agency. Washington D.C.

U.S. Environmental Protection Agency (EPA). 1990. National Emission Standards for Hazardous Air Pollutants. 40 CFR 61. Environmental Protection Agency, U.S. Code of Federal Regulations. 1990.

WAC 1994. Radiation Protection - Air Emissions, WAC 246-247, Washington Administrative Code. Washington Department of Health.

WDOE 1997. State Waste Discharge Permit for the Discharge of Hydrotest, Maintenance, and Construction Discharges, ST-4508. Washington State Department of Ecology

WDOE 2001. Hantord Site Air Operating Permit, \#00-05-006. Washington State Department of Ecology.

Westinghouse Hanford Company. 1989. Waste Stream Characterization Report, WHC-EP-0287. Westinghouse Hanford Company. Richland, Washington. 



\section{Appendix A}

\section{Projection of Offsite Emission Dose}

DOE Order 5400.1 states that Environmental Monitoring Plans (EMP) "shall be prepared for each site, facility, or process that uses, generates, releases, or manages significant pollutants or hazardous materials" (DOE Order 5400.1, IV-2). To support the EMP, Facility Effluent Monitoring Plans (FEMPs) are being prepared for those facilities that have the potential to release significant pollutants or hazardous materials. A methodology has been developed to determine whether potential releases of radioactive material are significant. This method is the same as that used to determine whether monitoring is required for the National Emission Standards for Hazardous Air Pollutants (NESHAP - U.S. Code of Federal Regulations, Title 40 Part 61, Subpart H) and is described in Assessment of Unabated Facility Emission Potentials for Evaluating Airborne Radionuclide Monitoring Requirements at Pacific Northwest National Laboratory - 2001. (Ballinger et al. 2001, PNL-10855, Rev. 2).

The first step in the method (called the FEMP Determination when used to determine whether or not a FEMP is needed for a facility) is to obtain a listing of the facility inventory. The inventory includes the radionuclide, isotope, quantity, and form. Form can be gas, liquid or powder, solid (nondispersible), contained (in sealed sourced or DOT containers), or exempt (sealed sources meeting certain criteria). At PNNL, radicactive source and material information is maintained using three separate inventory systems: (1) facilities management radioactive materials inventory, (2) composite radioactive materials inventory, and (3) nuclear materials inventory. Additional detail on the FEMP Determination method is provided in PNL-10855, Rev. 2. A table is provided showing a listing by nuclide of the radioactive material inventory in 331 for the 2001 assessment. The table shows the total activity and the percent contribution to the total unabated Potential-to-Emit for the facility. The PTE was less than $0.1 \mathrm{mrem} / \mathrm{year}$, but the main stack was still treated as a major emission point because the projects allowed in the building could cause the PTE to increase to above $0.1 \mathrm{mrem} / \mathrm{year}$. The sealed source inventories for $331 \mathrm{G}$ and $331 \mathrm{H}$ have no Potential-toEmit and are not included. 
Table A.1

FEMP Dose Contribution by Nuclide for: 331 Building

\section{Total PTE Dose: 7.38E-02 mrem/yr}

\begin{tabular}{|c|c|c|c|}
\hline Nuclide & $\begin{array}{l}\text { Inventory } \\
\text { (Ci) }\end{array}$ & $\begin{array}{c}\text { Dose } \\
\text { (mrem/vr) }\end{array}$ & $\begin{array}{c}\% \text { of Total } \\
\text { Dose }\end{array}$ \\
\hline $\mathrm{Am}-241$ & $1.71 \mathrm{E}-00$ & $3.30 \mathrm{E}-03$ & $4.47 \%$ \\
\hline Ba-133 & $5.50 \mathrm{E}-03$ & 0 & $0.00 \%$ \\
\hline$C-14$ & $7.74 \mathrm{E}-02$ & 1.86E-08 & $0.00 \%$ \\
\hline $\mathrm{Cl}-36$ & $2.04 \mathrm{E}-08$ & 0 & $0.00 \%$ \\
\hline $\mathrm{Cm}-248$ & $4.20 \mathrm{E}-07$ & $1.83 \mathrm{E}-06$ & $0.00 \%$ \\
\hline $\mathrm{Co}-60$ & $4.90 \mathrm{E}+04$ & 0 & $0.00 \%$ \\
\hline Cs-137 & $4.00 \mathrm{E}-02$ & $5.19 \mathrm{E}-12$ & $0.00 \%$ \\
\hline Eu-152 & $2.00 \mathrm{E}-02$ & $2.83 \mathrm{E}-10$ & $0.00 \%$ \\
\hline $\mathrm{H}-3$ & $1.26 \mathrm{E}-01$ & $3.64 \mathrm{E}-08$ & $0.00 \%$ \\
\hline $1-125$ & 1.00E-01 & 2.26E-05 & $0.03 \%$ \\
\hline $1-129$ & $4.77 \mathrm{E}-07$ & 0 & $0.00 \%$ \\
\hline $\mid-131$ & $5.01 \mathrm{E}-03$ & 6.22E-06 & $0.01 \%$ \\
\hline $\mathrm{Na}-22$ & 1.50E-08 & 0 & $0.00 \%$ \\
\hline $\mathrm{Ni}-63$ & $1.20 \mathrm{E}-01$ & 0 & $0.00 \%$ \\
\hline Np-237 & $1.20 \mathrm{E}-02$ & $1.26 \mathrm{E}-02$ & $17.07 \%$ \\
\hline$P-32$ & $1.00 E-01$ & $1.31 \mathrm{E}-06$ & $0.00 \%$ \\
\hline Po-210 & $1.76 \mathrm{E}-07$ & 0 & $0.00 \%$ \\
\hline Pu(12\%) & $5.16 E-01$ & $3.96 \mathrm{E}-07$ & $0.00 \%$ \\
\hline Pu(6\%) & $1.98 \mathrm{E}-01$ & 0 & $0.00 \%$ \\
\hline Pu-238 & $1.71 \mathrm{E}-00$ & $1.87 \mathrm{E}-03$ & $2.54 \%$ \\
\hline Pu-239 & $6.58 \mathrm{E}-02$ & 4.59E-02 & $62.26 \%$ \\
\hline $\mathrm{Pu}-240$ & $1.03 \mathrm{E}-02$ & $7.55 \mathrm{E}-03$ & $10.23 \%$ \\
\hline Pu-241 & $1.69 \mathrm{E}=01$ & $1.88 \mathrm{E}-03$ & $2.55 \%$ \\
\hline Pu-242 & 4.59E-05 & $3.19 \mathrm{E}-05$ & $0.04 \%$ \\
\hline Ra-226 & $4.50 \mathrm{E}-10$ & 0 & $0.00 \%$ \\
\hline S-35 & $1.52 \mathrm{E}-01$ & $1.01 \mathrm{E}-07$ & $0.00 \%$ \\
\hline Sr-90 & $8.28 \mathrm{E}-03$ & 0 & $0.00 \%$ \\
\hline Tc-99 & $5.50 \mathrm{E}-02$ & $8.40 E-08$ & $0.00 \%$ \\
\hline Th-230 & $1.98 \mathrm{E}-02$ & 0 & $0.00 \%$ \\
\hline Th-232 & 9.81E-06 & 2.79E-06 & $0.00 \%$ \\
\hline$U(\mathrm{Dep})$ & 7.81E-05 & $1.96 E-05$ & $0.03 \%$ \\
\hline U(Nat) & $2.08 \mathrm{E}-03$ & $5.23 \mathrm{E}-04$ & $0.71 \%$ \\
\hline U-238 & $3.85 \mathrm{E}-04$ & $3.76 \mathrm{E}-05$ & $0.05 \%$ \\
\hline Y-90 & 3.50E-02 & $7.05 \mathrm{E}-07$ & $0.00 \%$ \\
\hline
\end{tabular}




\section{Appendix B}

\section{Nonradioactive Hazardous Materials Characterization}

DOE Order 5400.1 states that Environmental Monitoring Plans (EMP) "shall be prepared for each site, facility, or process that uses, generates, releases, or manages significant pollutants or hazardous materials" (DOE Order 5400.1, IV-2). The Facility Effluent Monitoring Plans (FEMPs) being prepared to support the EMP include the consideration of nonradioactive hazardous materials.

A listing of the chemicals used in the building is obtained using the PNNL Chemical Management System (CMS). The inventory information includes the location, chemical name, and quantity. In some cases the manufacturer and individual container quantities are also tracked. In addition, the CMS data includes the reportable quantity (RQ) of the chemical. RQs are obtained from 40 CFR 302 and are the amounts that, if released to the environment from a facility, require notification to the National Response Center. To characterize the relative hazard of the building, the first table is prepared showing those chemicals that are reported to be present in greater than $R Q$ amounts in the 331 Building. The other 331 Complex facilities do not have chemicals in greater than reportable quantities. The second table is provided to show the range of chemicals that can be found in the 331 Building. As with the RQ list, the 331 support facilities have a more narrow range and smaller amounts than 331. 

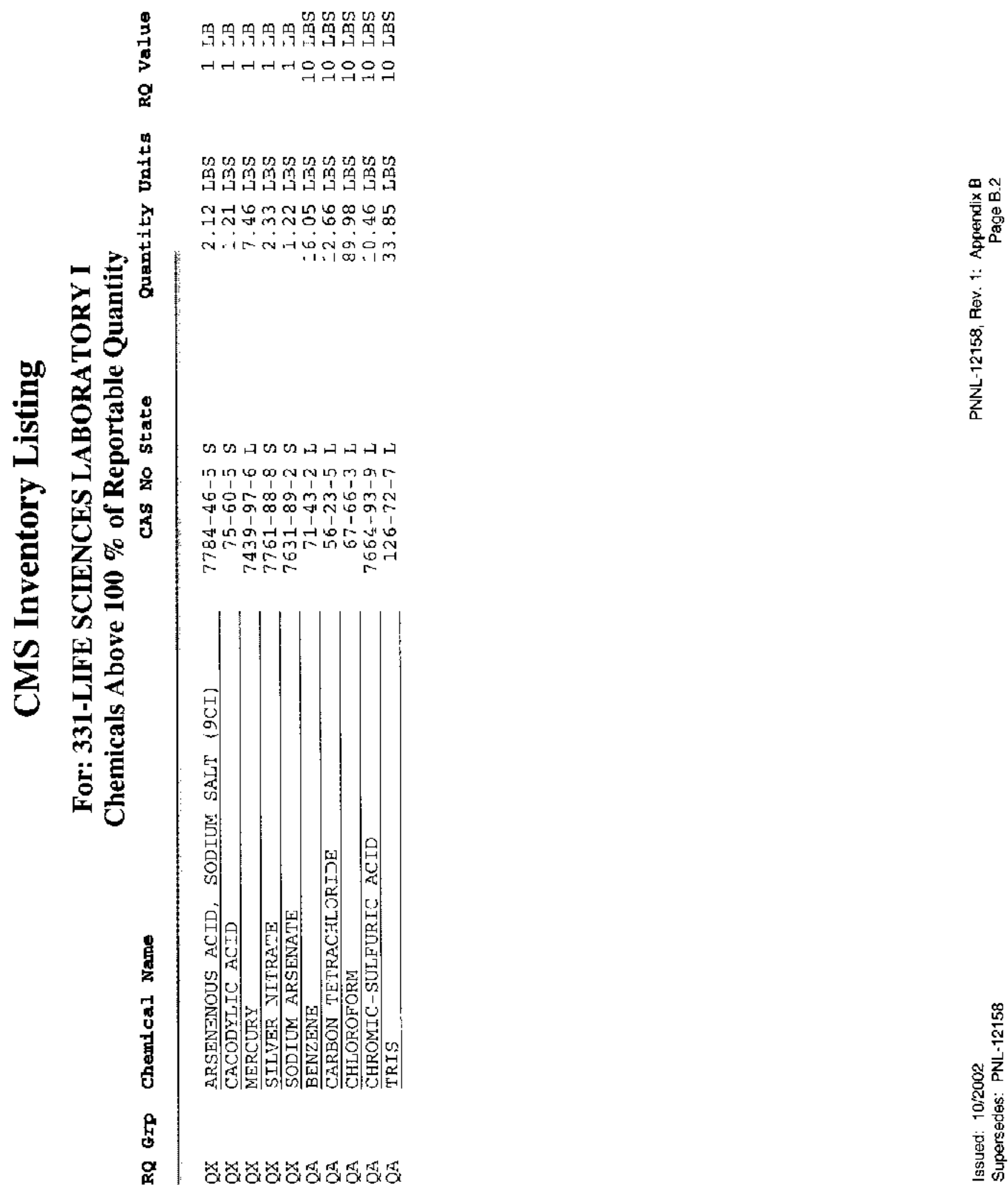


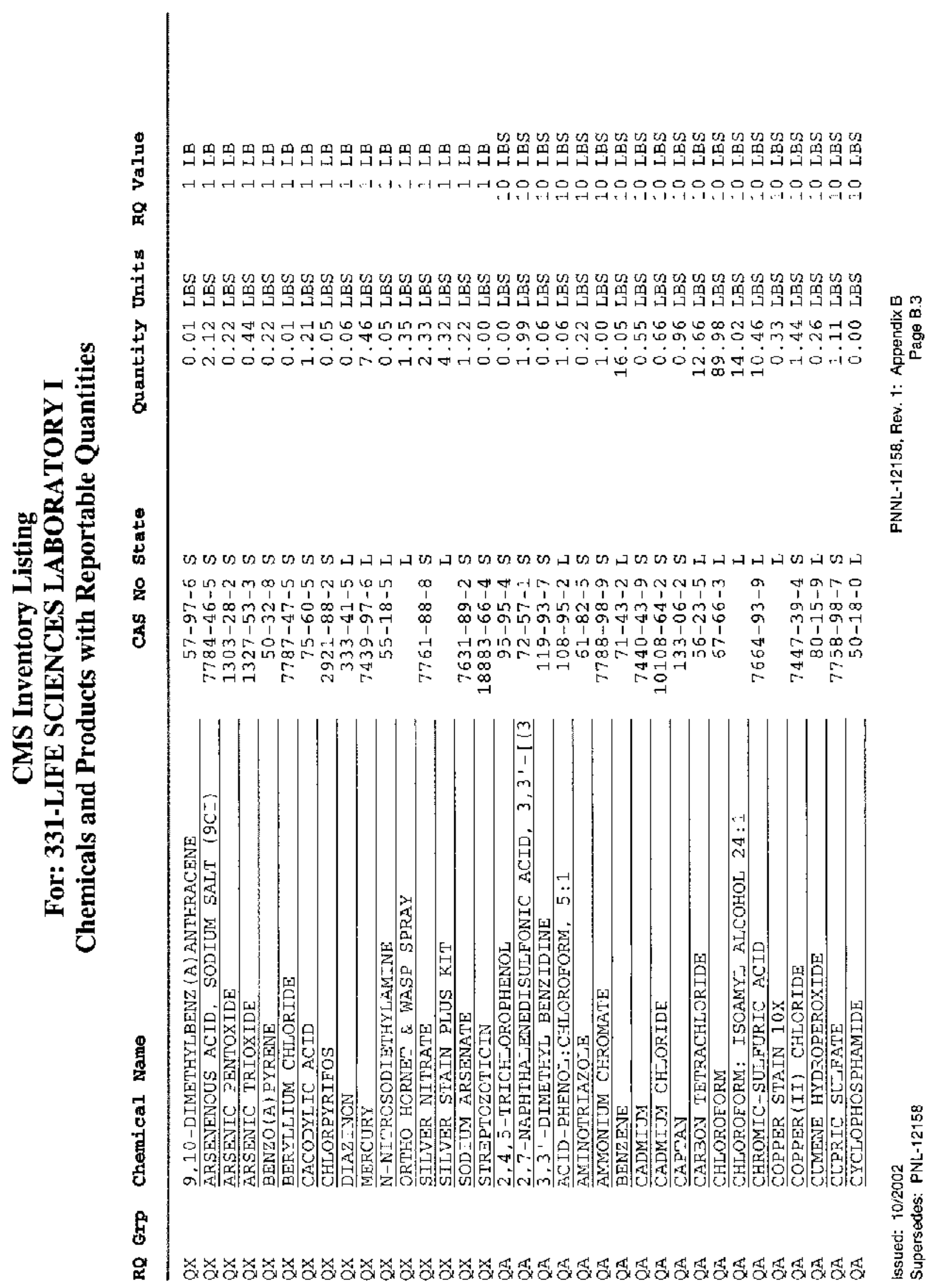




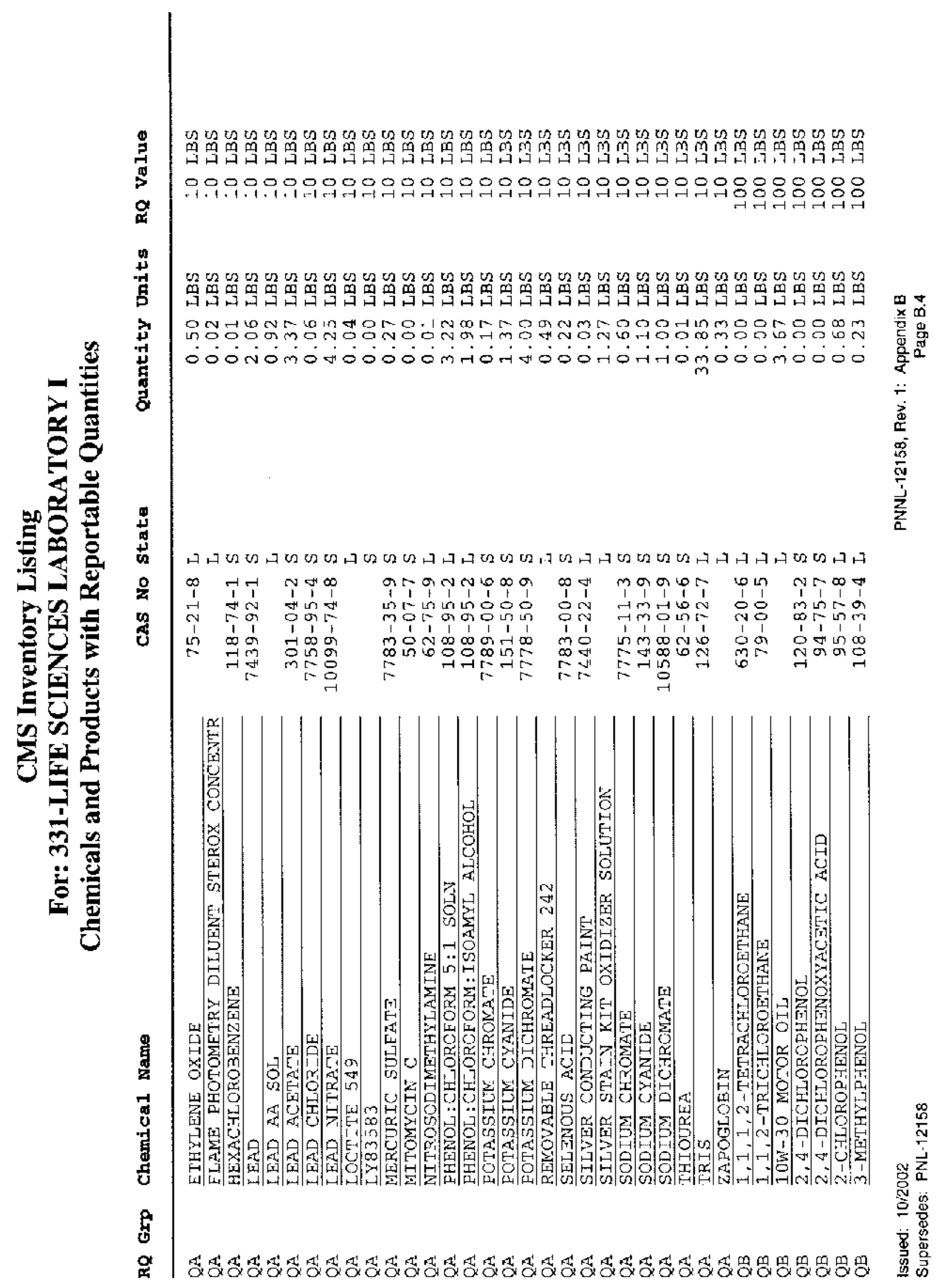




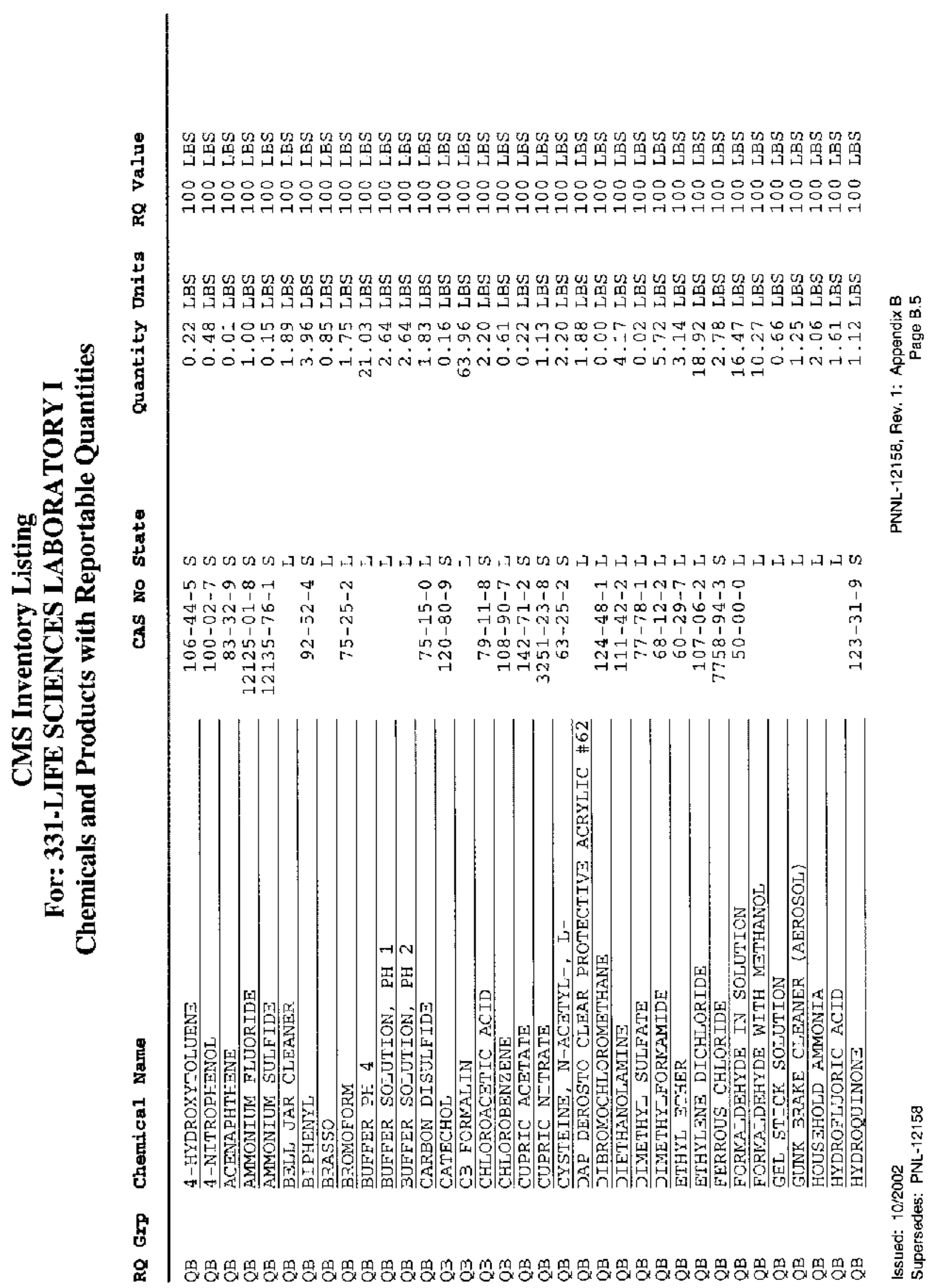




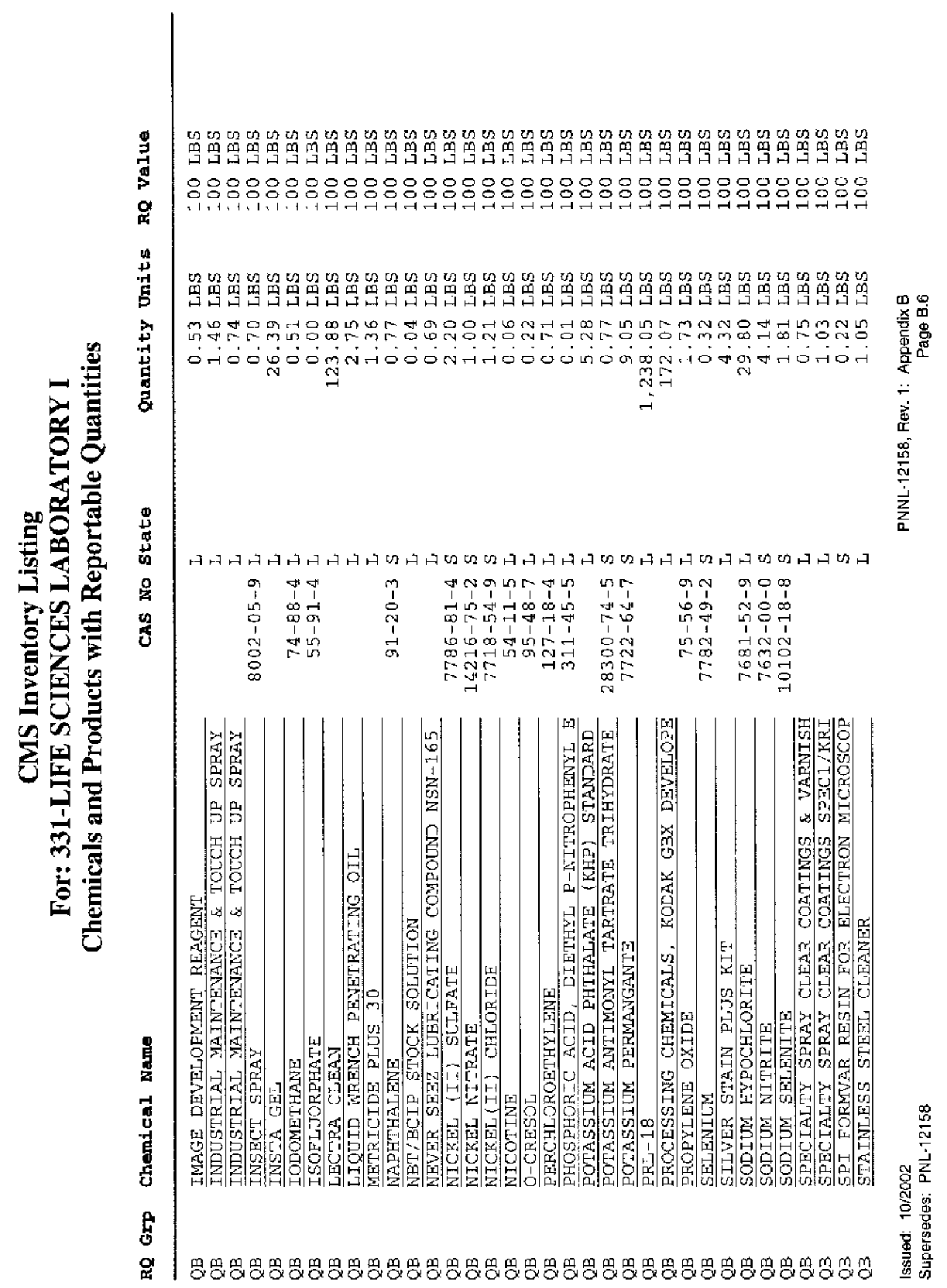




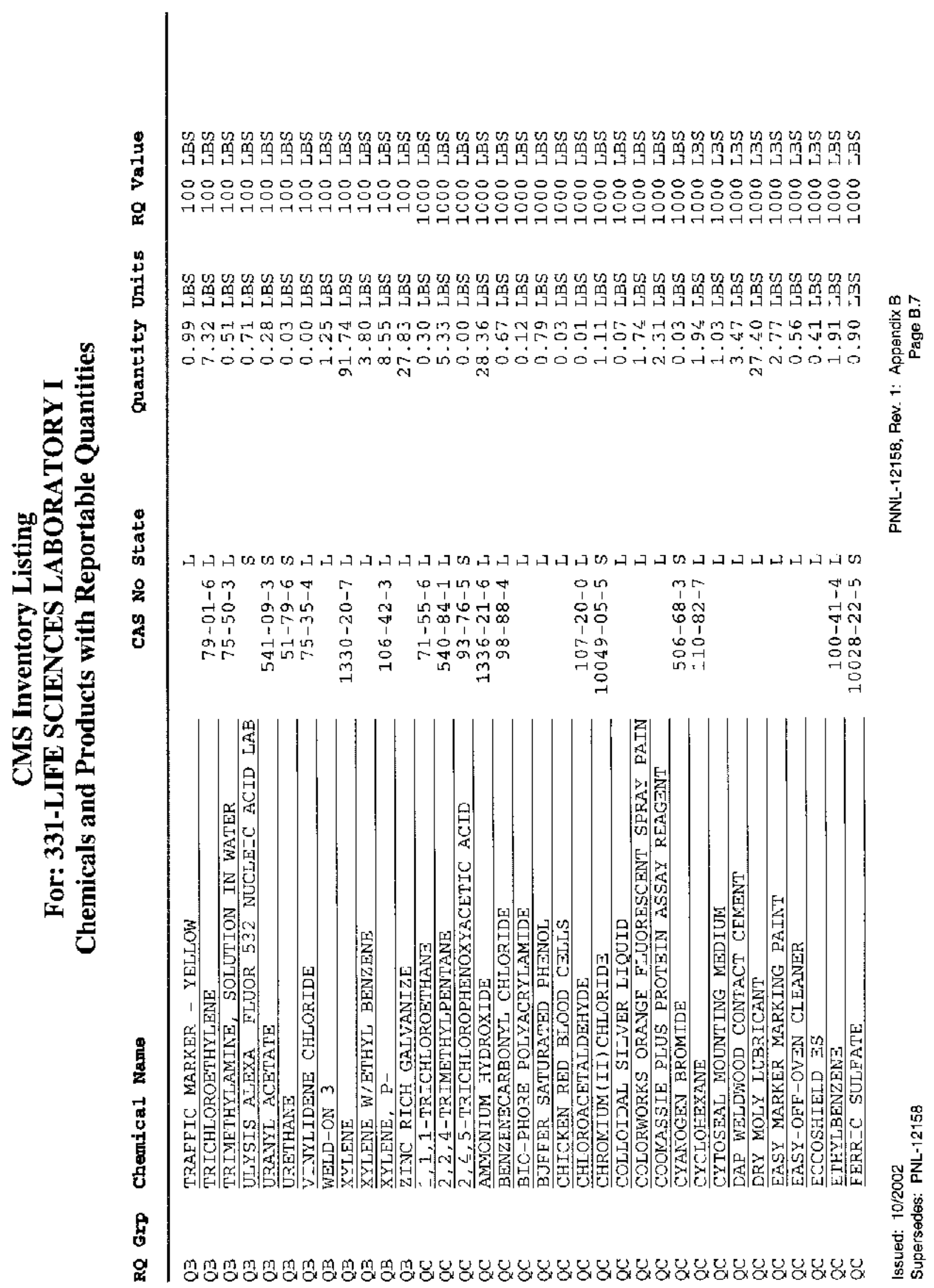




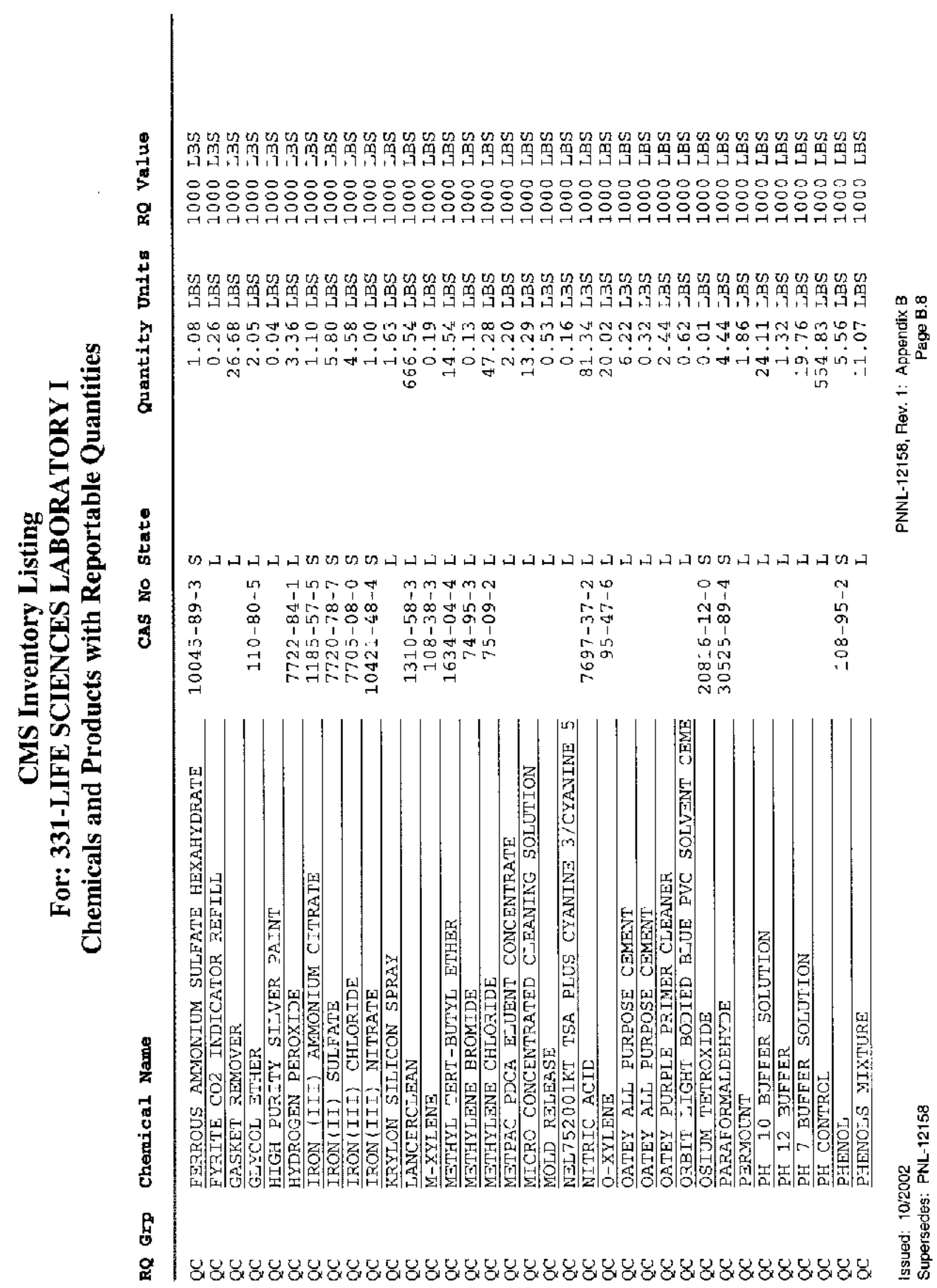




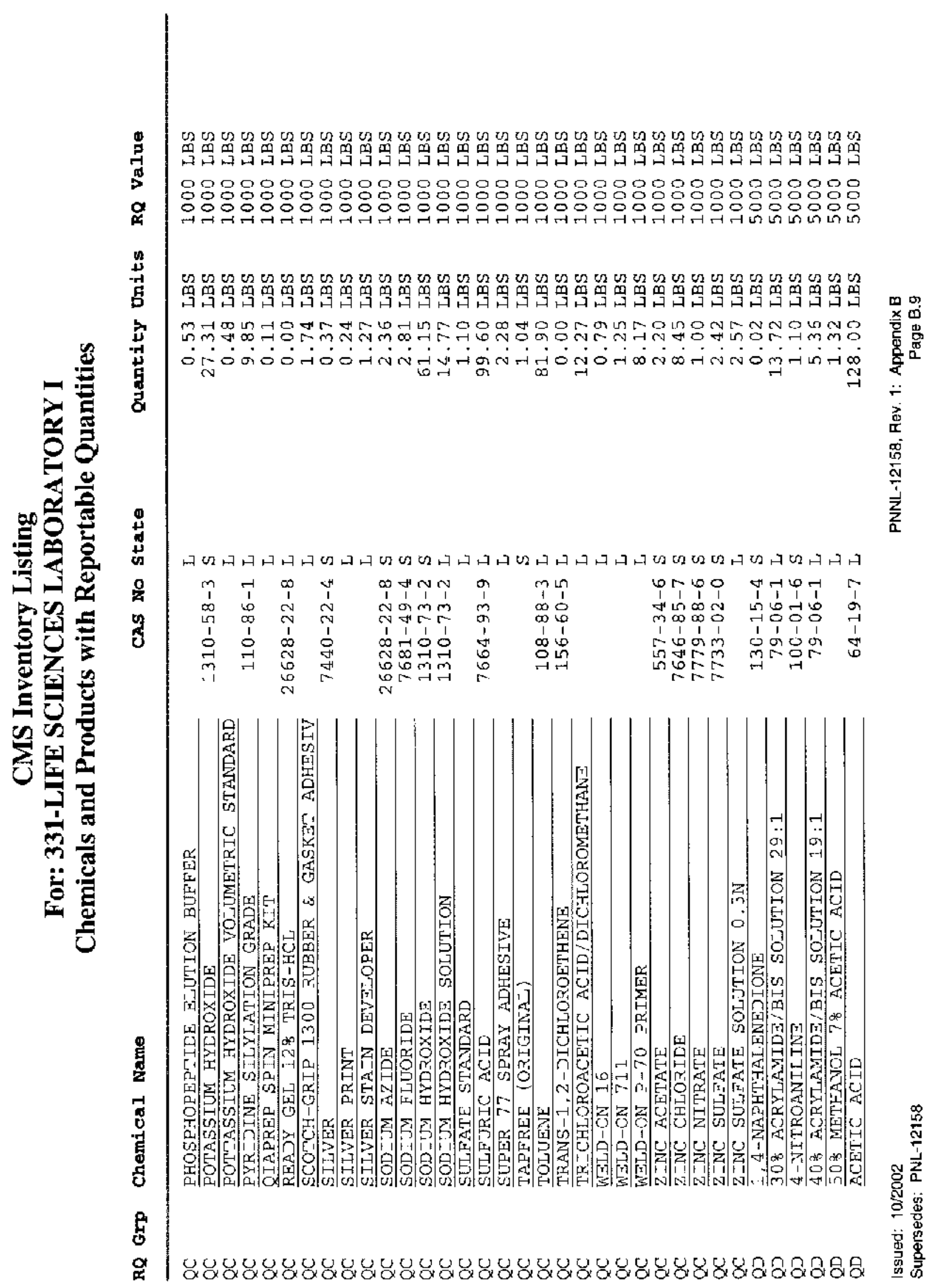




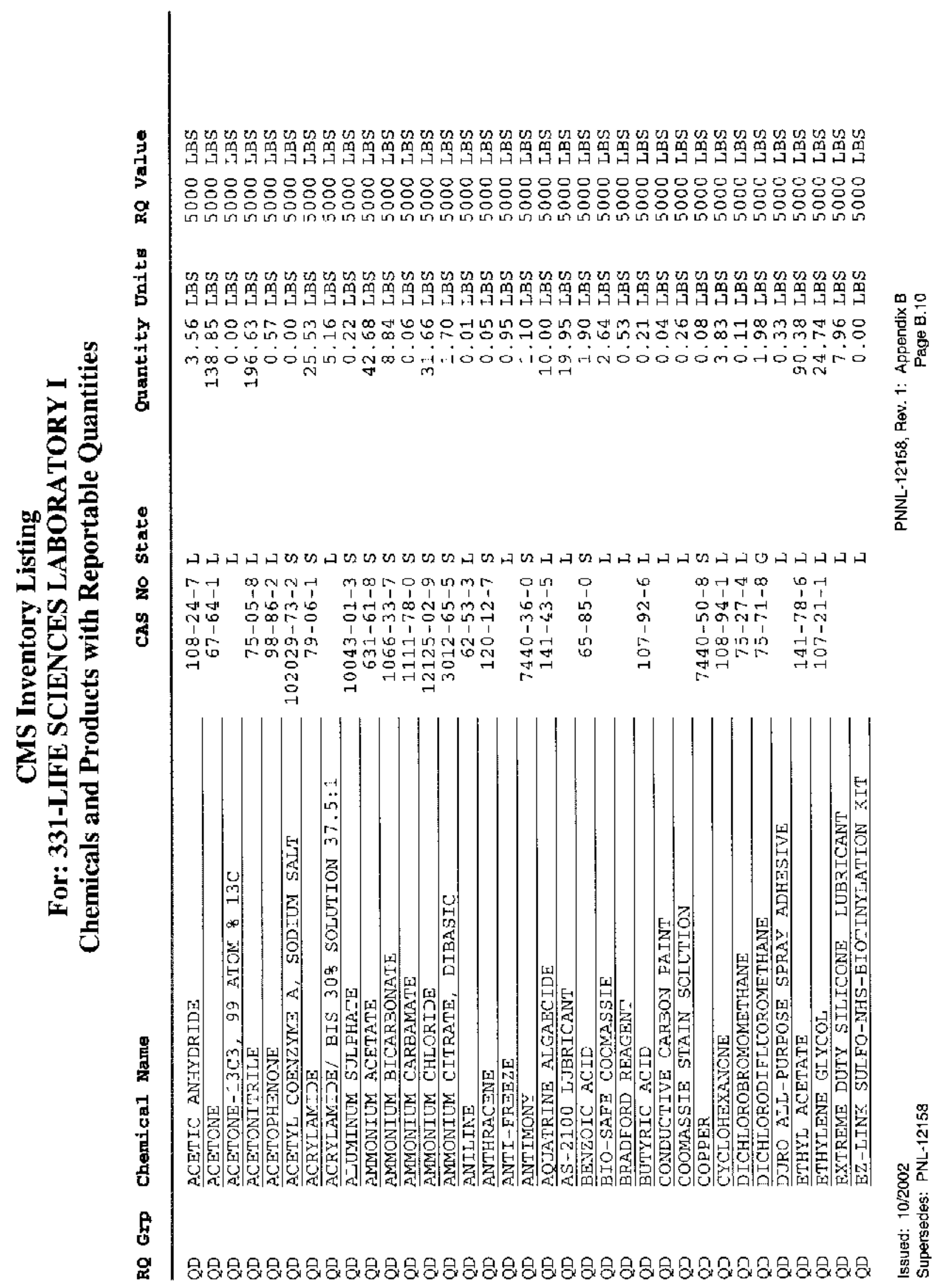




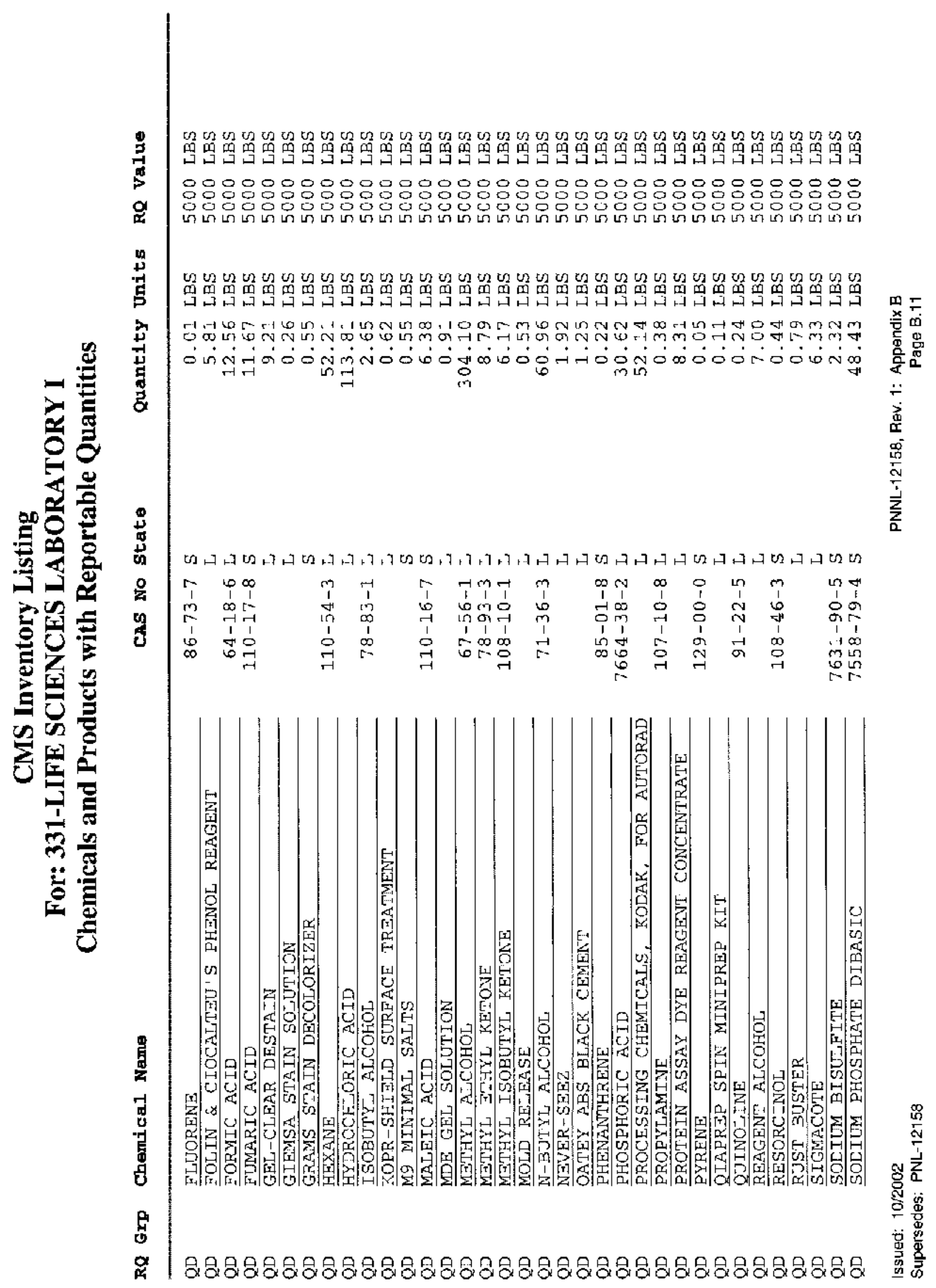



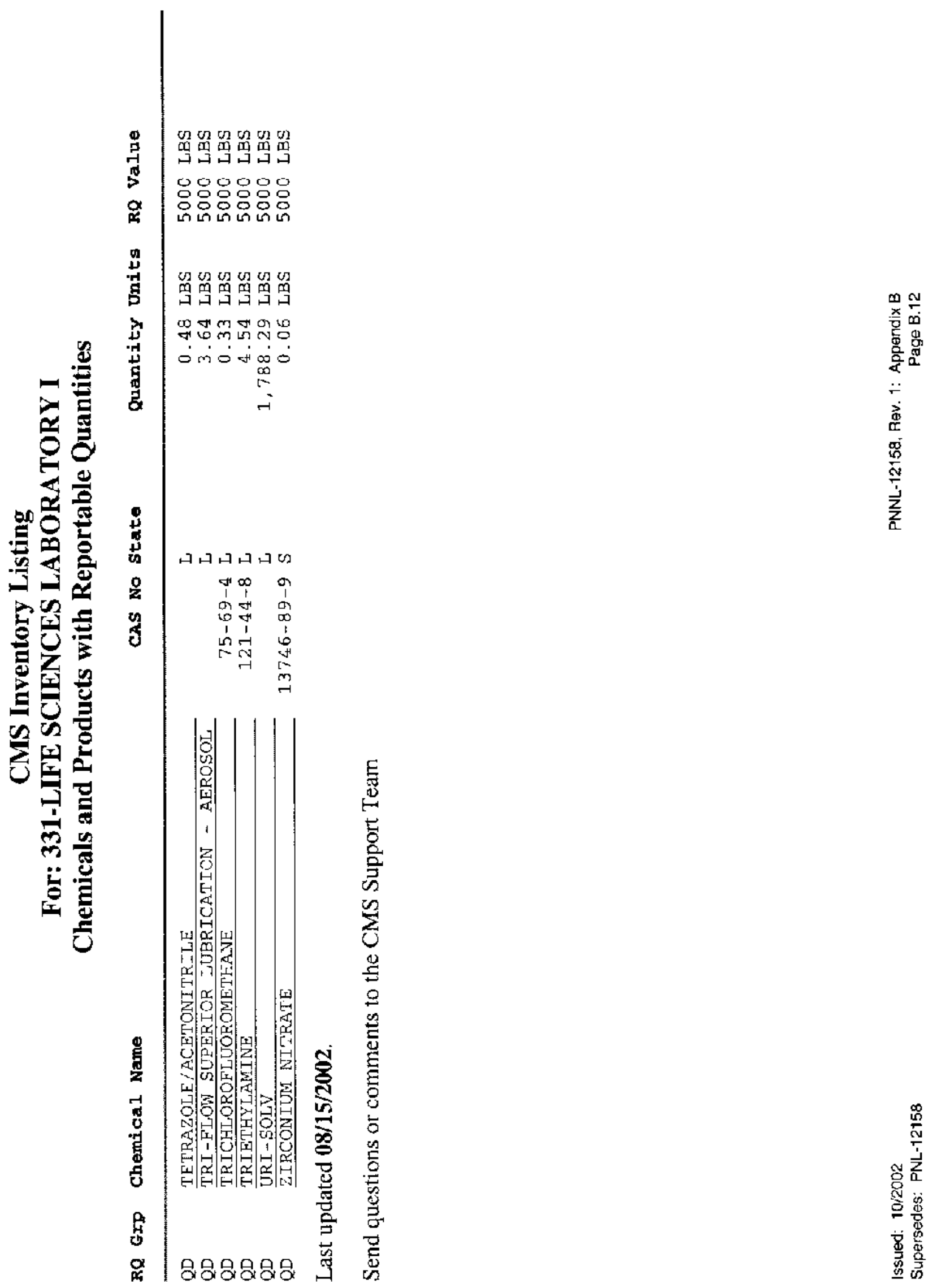


\section{Appendix C}

\section{Supporting Calculations}

Lab Corr Factor
Op Factor
Media Factor
Sampler Flow
Stack Flow
Stack Flow/Sample Flow
Transp. Factor
Detectable Release =

Detectable Release $=$

$\begin{array}{rr}\text { Particles } & \text { Composite Samples } \\ 0.85 & 1 \\ 1 & 1 \\ 0.91 & 0.91 \\ 3.4 \mathrm{cfm} & 3.4 \mathrm{cfm} \\ 60,600 \mathrm{~cm} & 60,600 \mathrm{cfm} \\ 18,053 \mathrm{cfm} & \\ 0.95 & 0.95\end{array}$

(MDA / Y r fraction) $\times$ (stack flowtsample flow) $\times 1$ E-12

Lab Corr, factor $\times$ Op. Factor $x$ Transport Factor $\times$ Media Factor

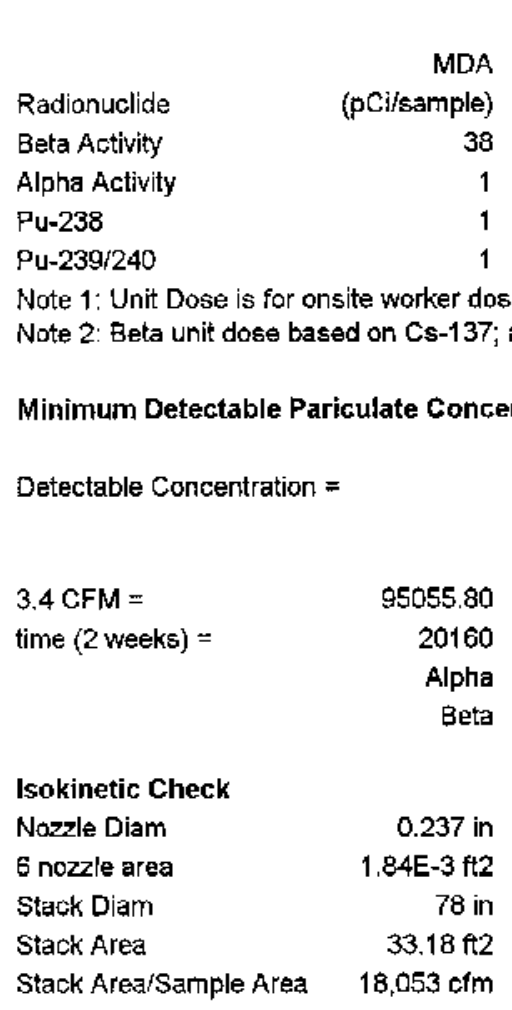


This page intentionally left blank. 


\section{Appendix D}

\section{Facility Effluent Pathway Drawings}

Current copies of the Key Drawings related to effluent pathways are included in this appendix. These drawings are current as of publishing this document. The official up-to-date version can be obtained from Battelle Engineering Files. 
This page intentionally left blank. 


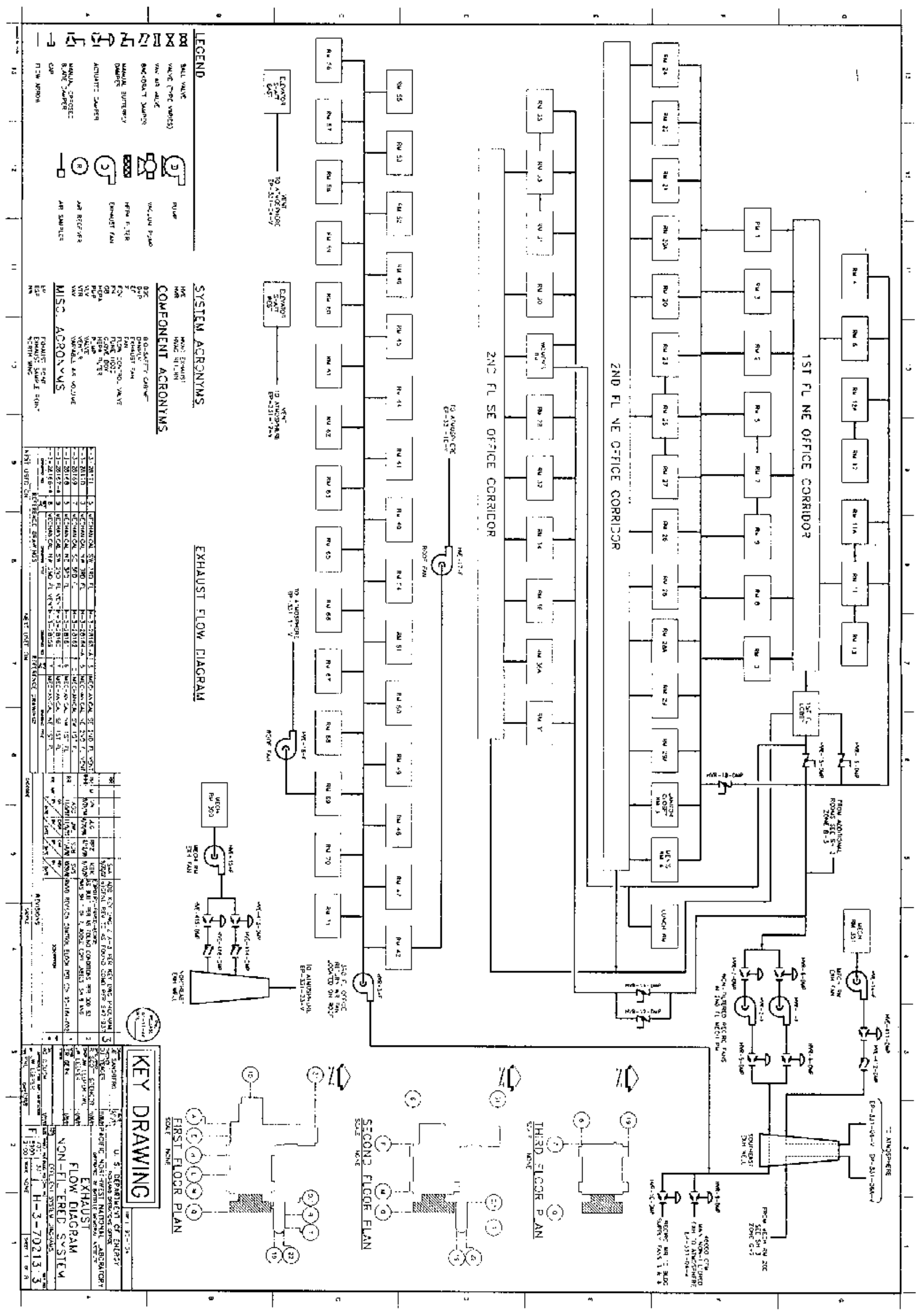




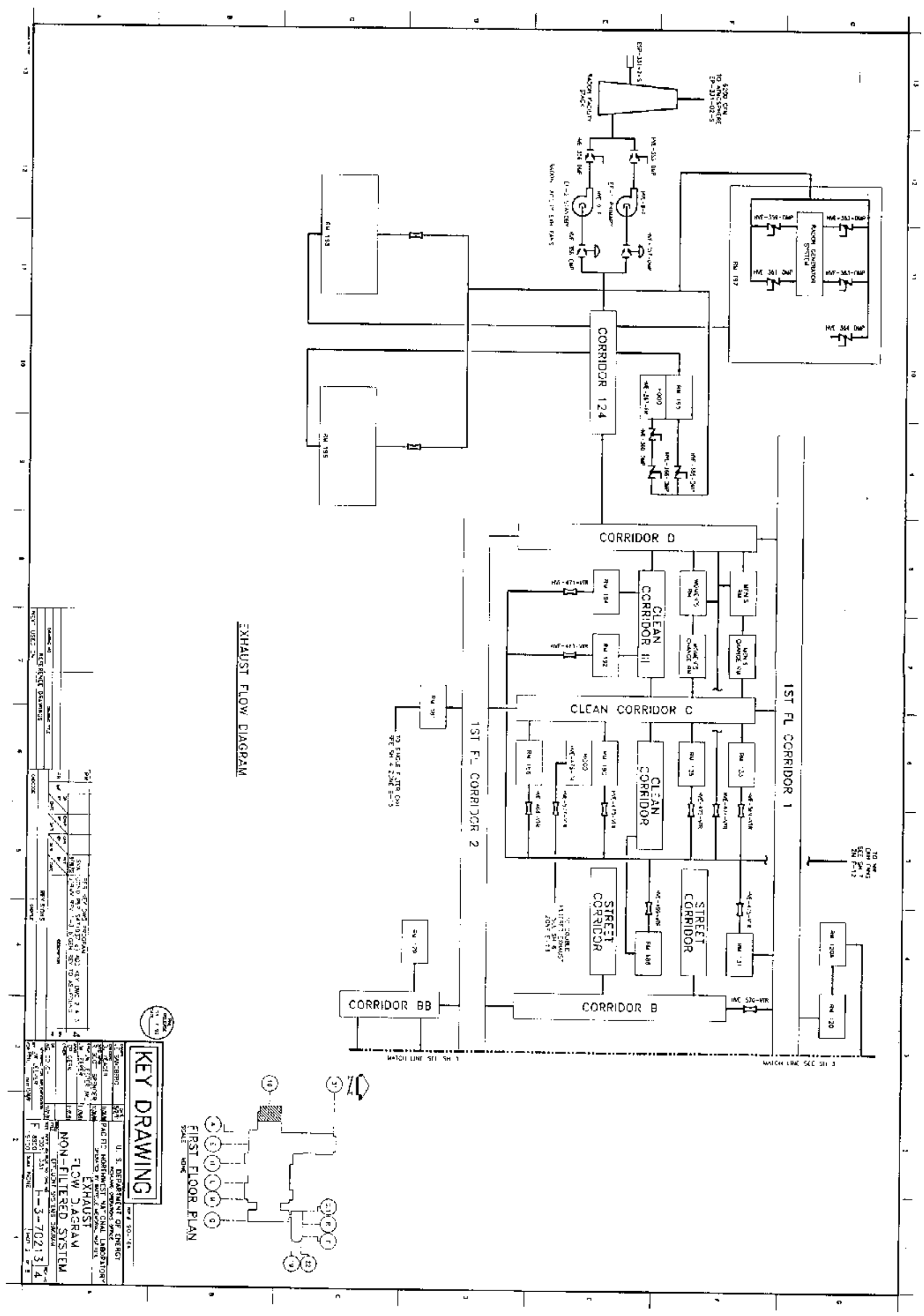




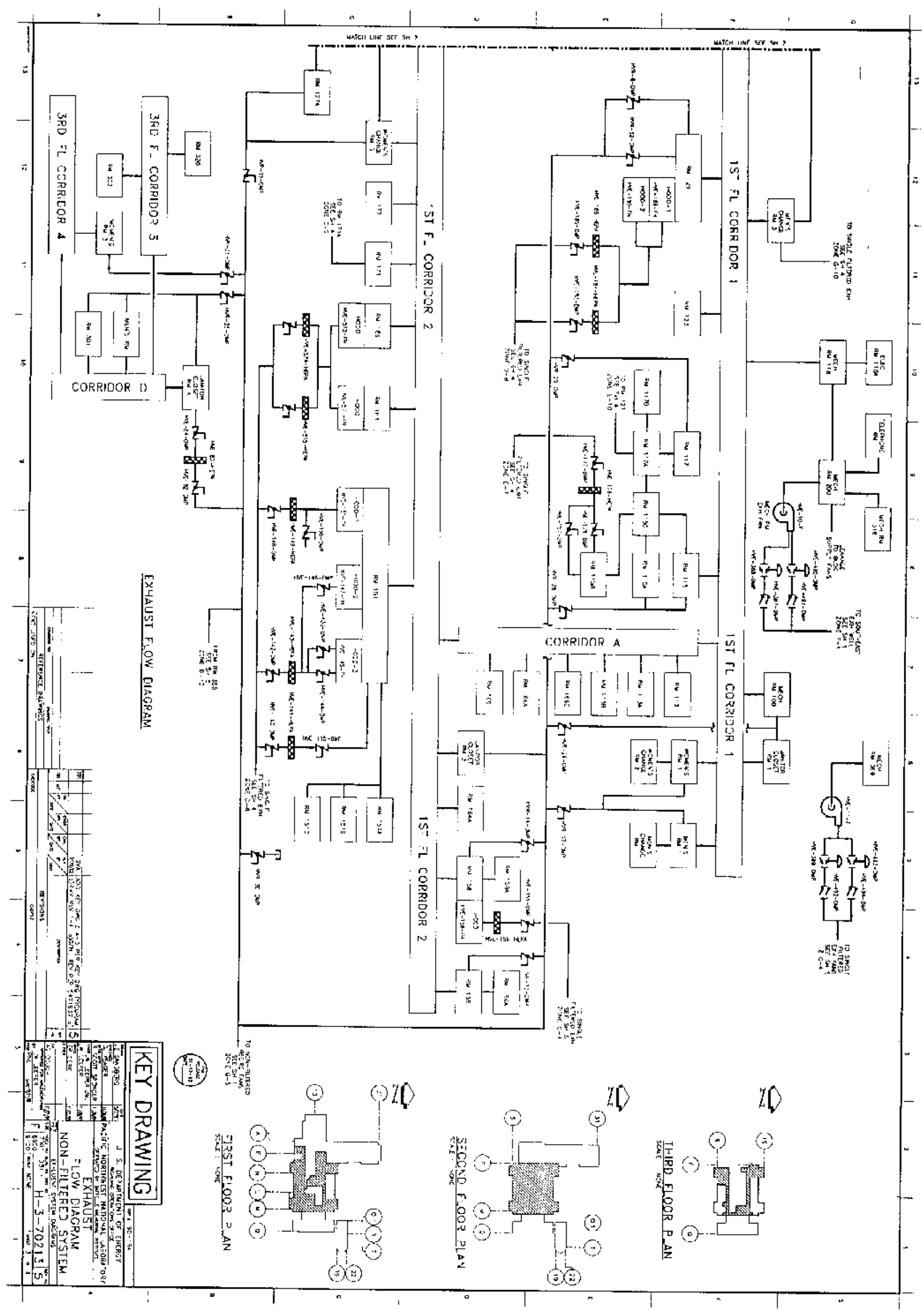




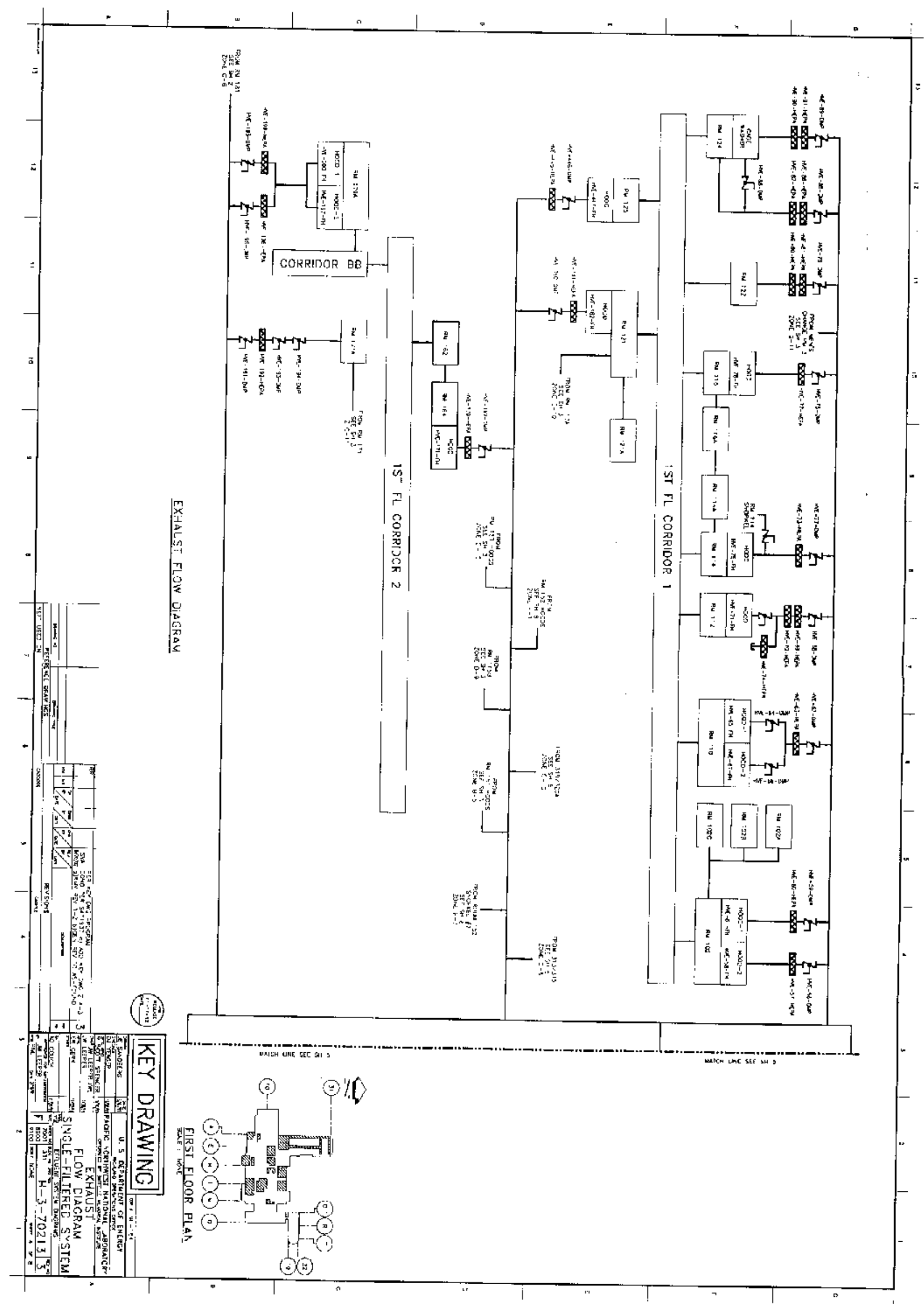




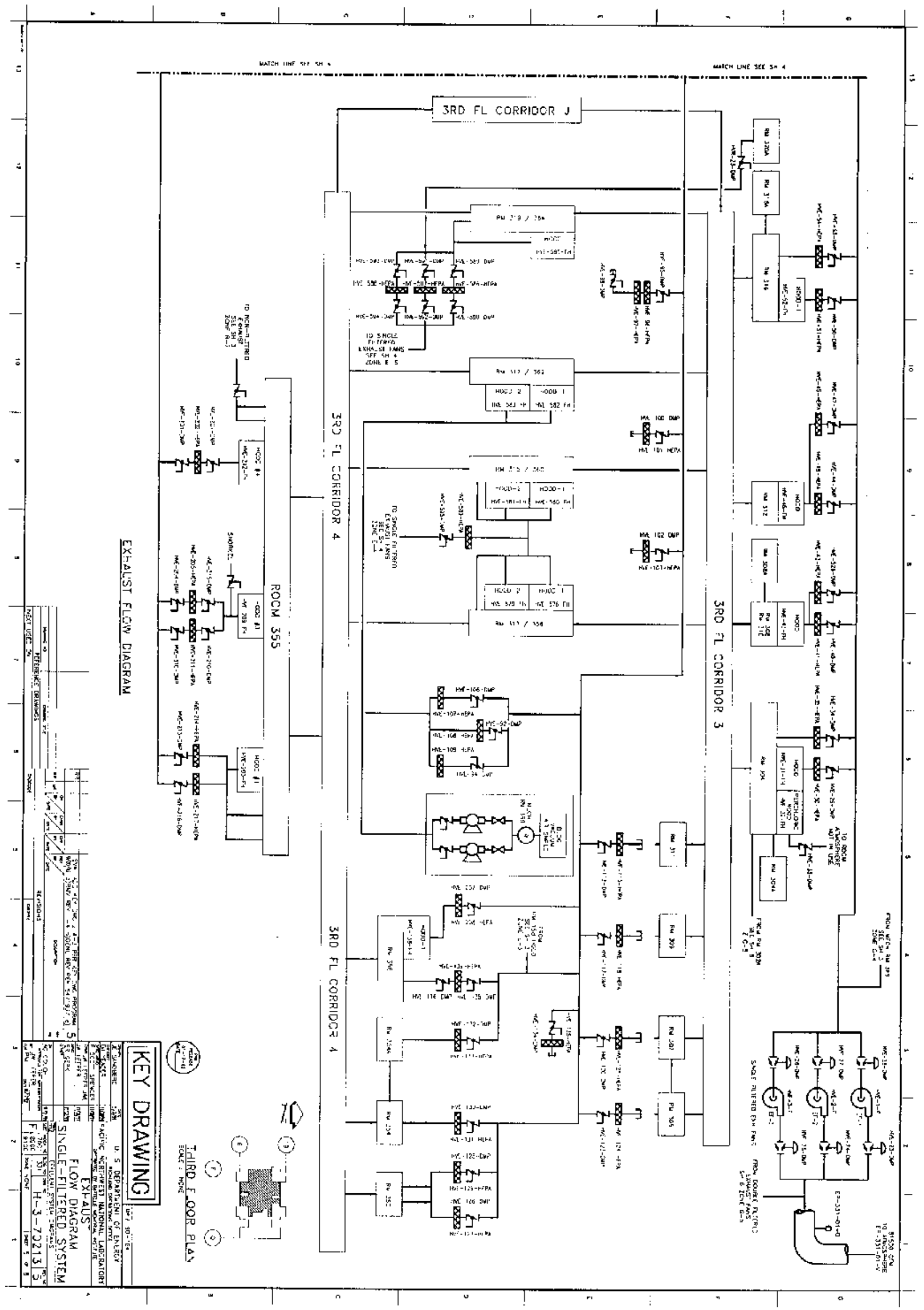




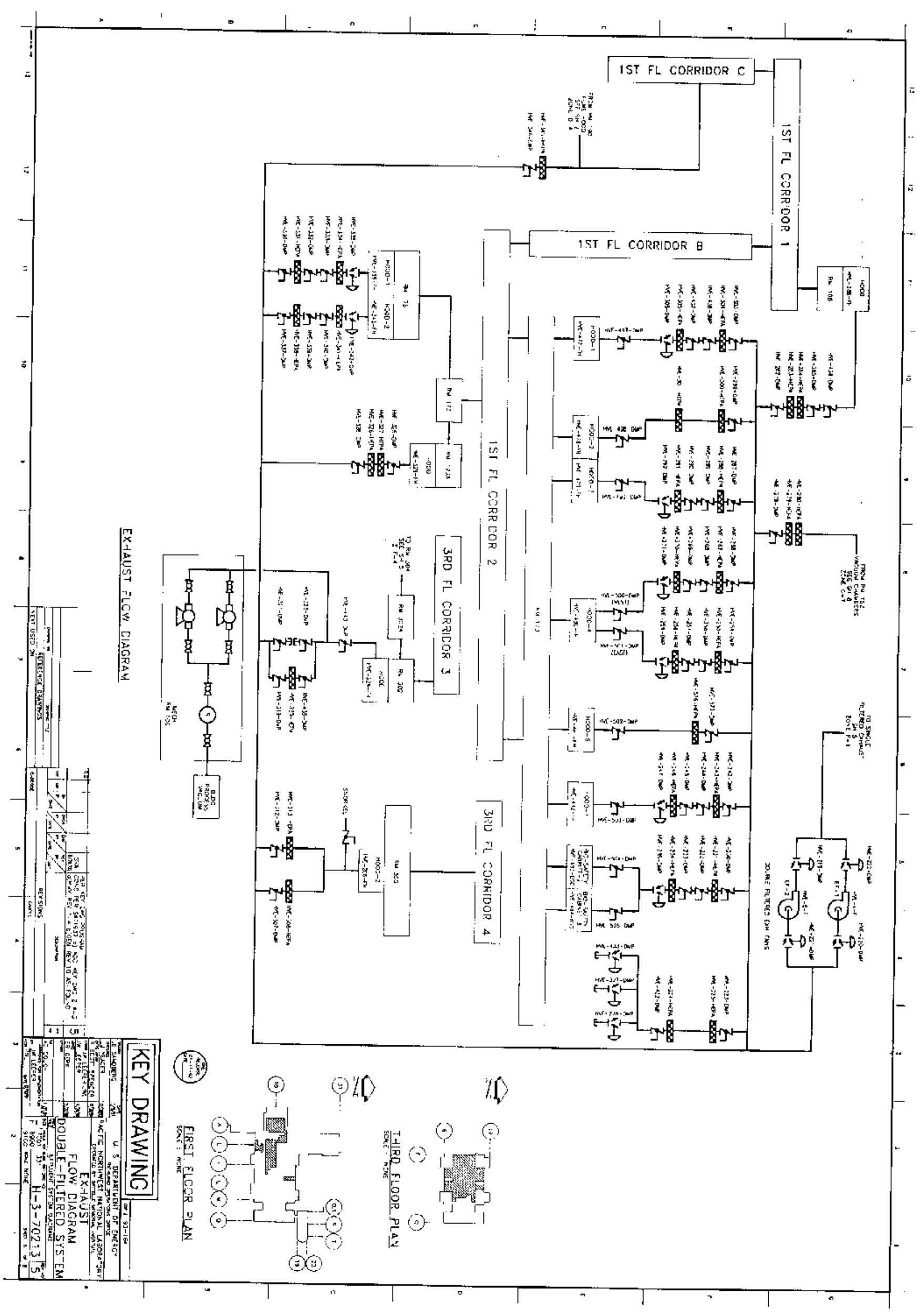




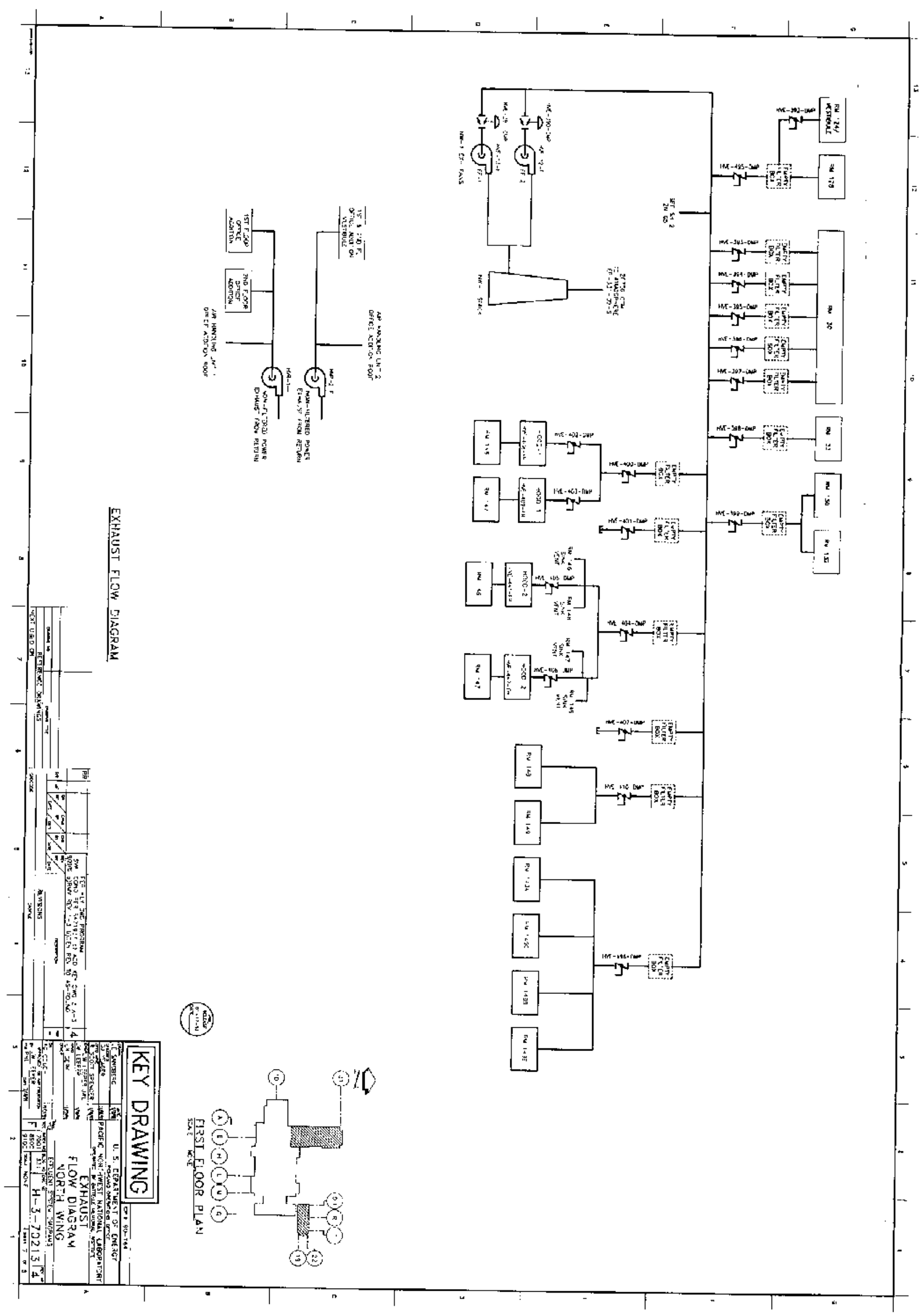




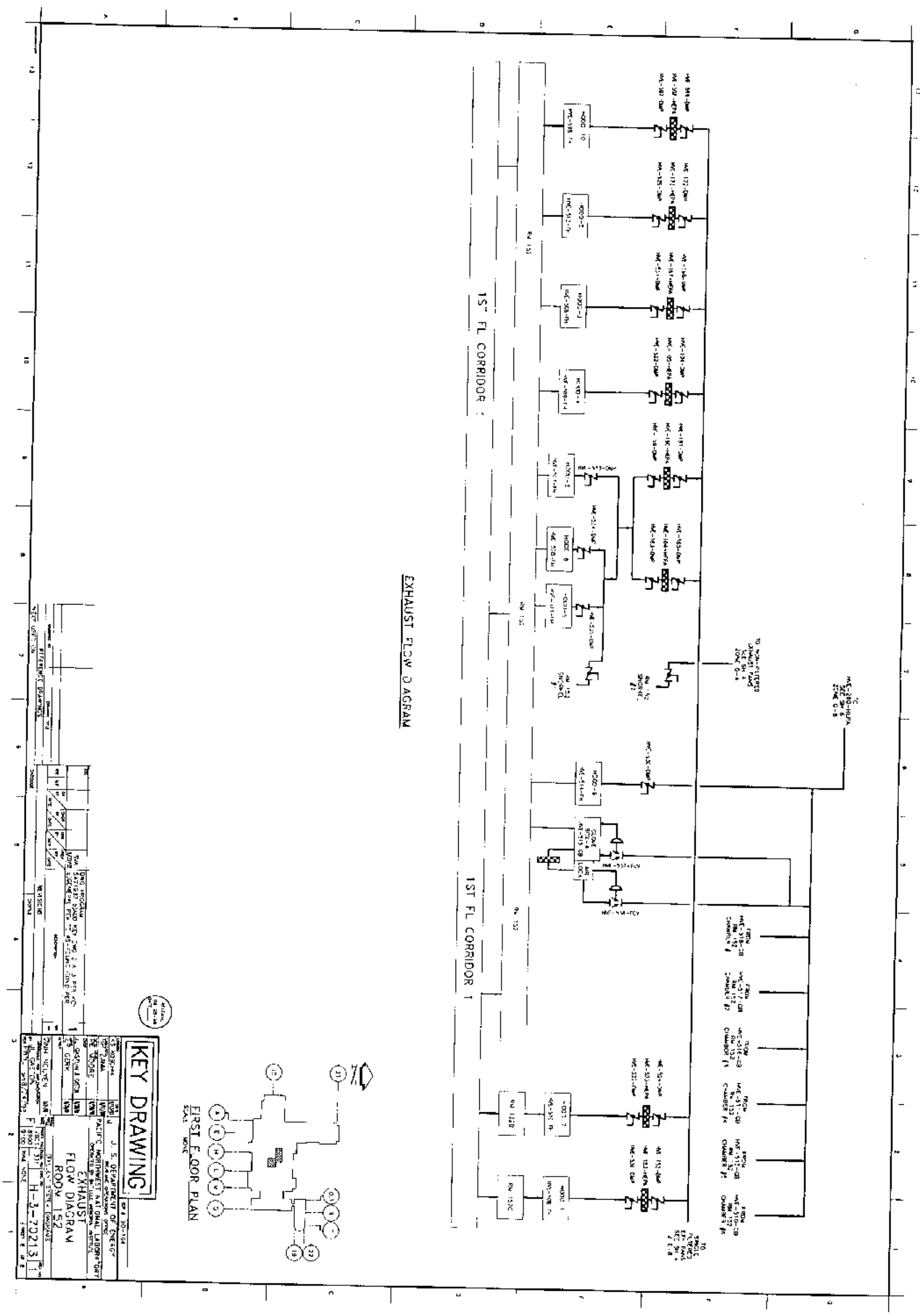




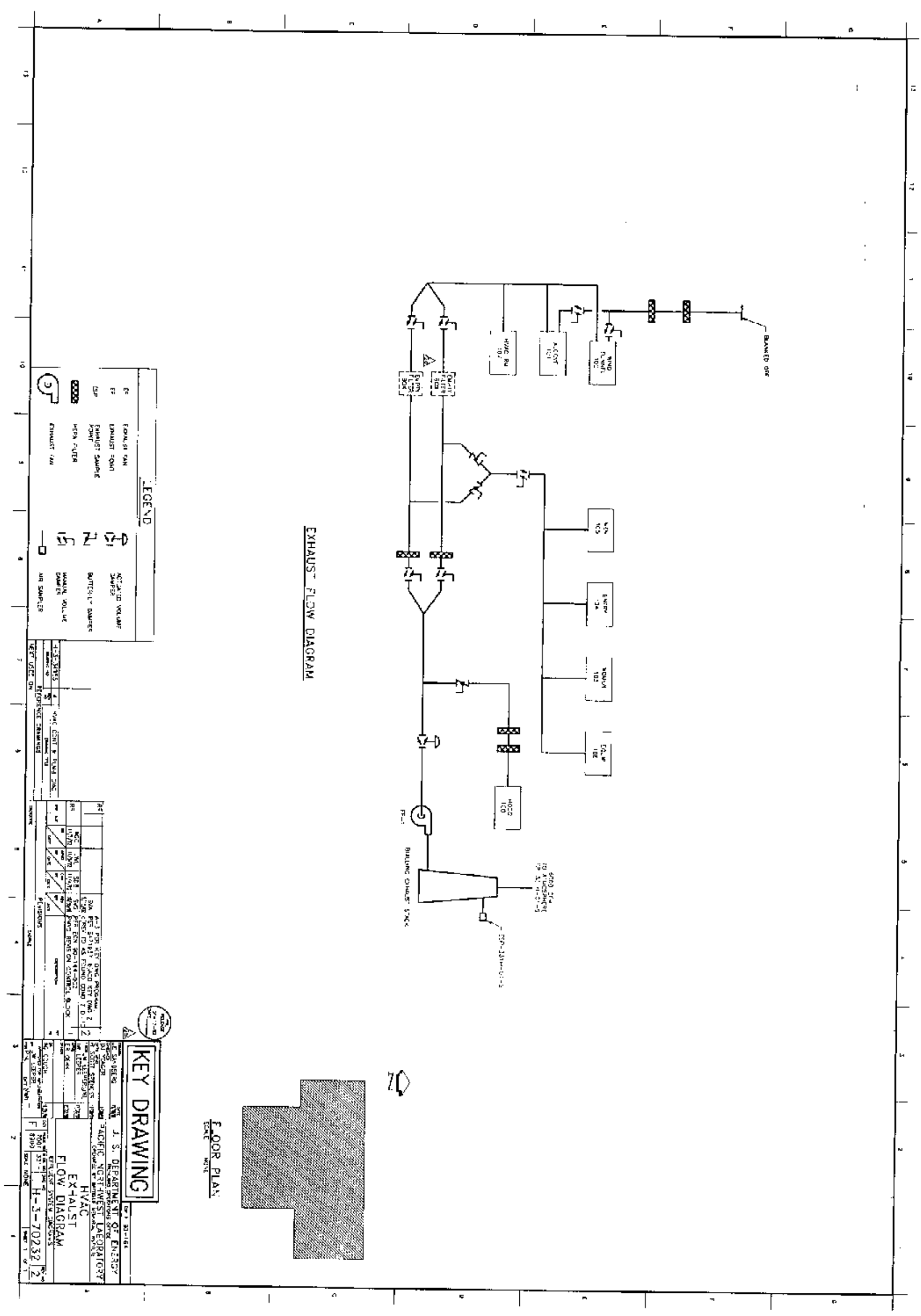




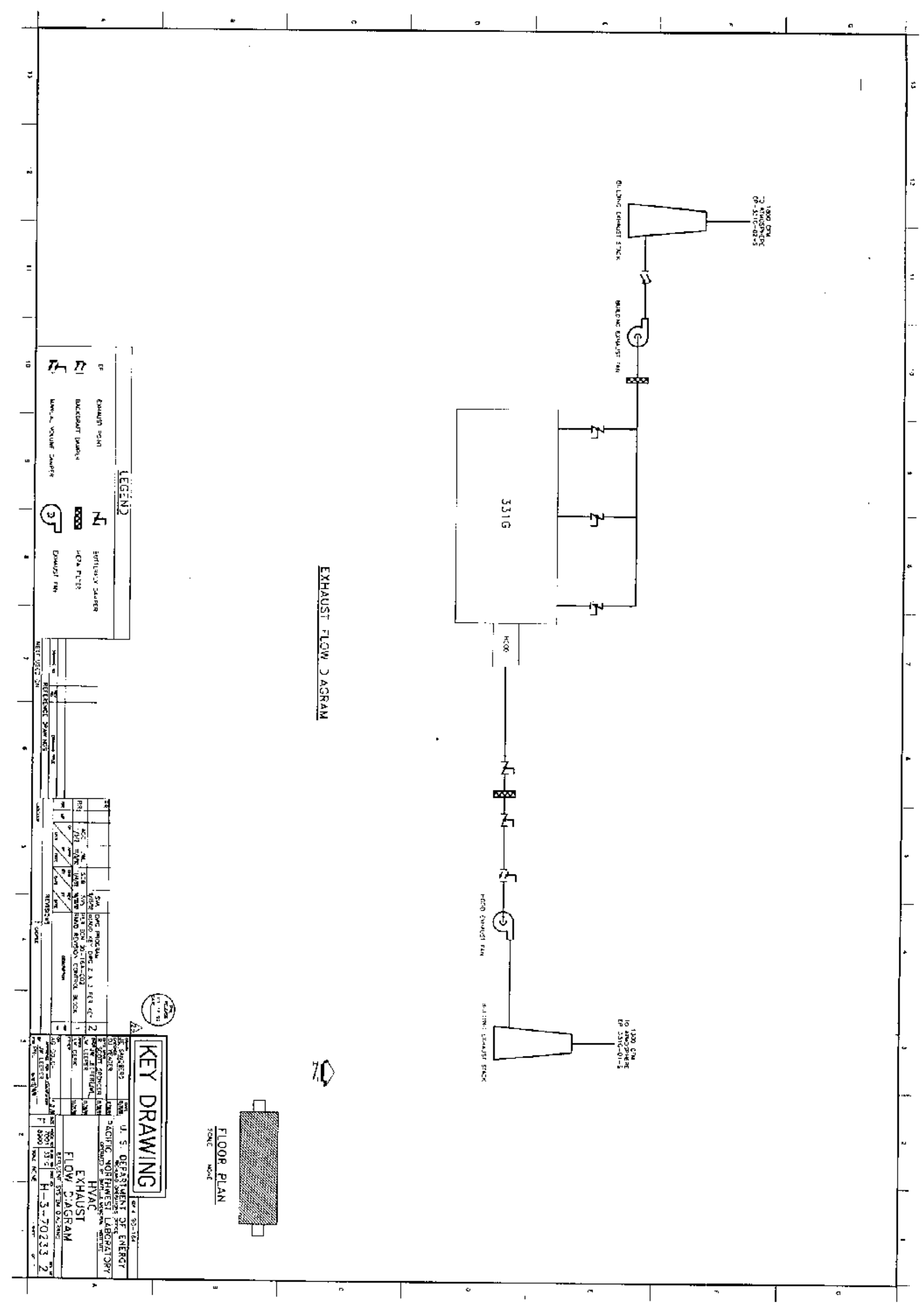

